IVONEI TURETTA

\title{
ANÁLISE DO DESGASTE DE ELETRODOS DE SOLDA POR RESISTÊNCIA A PONTO EM FUNÇÃO DO NÚMERO DE PONTOS SOLDADOS EM CHAPAS GALVANIZADAS.
}

São Paulo 


\title{
ANÁLISE DO DESGASTE DE ELETRODOS DE SOLDA POR RESISTÊNCIA A PONTO EM FUNÇÃO DO NÚMERO DE PONTOS SOLDADOS EM CHAPAS GALVANIZADAS.
}

\author{
Dissertação apresentada a Escola \\ Politécnica da Universidade de São Paulo \\ como requisito para obtenção do título de \\ Mestre em Engenharia. \\ Área de concentração: \\ Engenharia Metalúrgica e de Materiais. \\ Orientador: \\ Professor Dr. Cláudio Geraldo Schön.
}

São Paulo 
Este exemplar foi revisado e corrigido em relação a versão original, sob responsabilidade única do autor e com a anuência de seu orientador.

São Paulo de de

Assinatura do autor:

Assinatura do orientador:

FICHA CATALOGRÁFICA

TURETTA, IVONEI

ANALISE DO DESGASTE DE ELETRODOS DE SOLDA POR RESISTEENCIA A PONTO EM FUNCẢO DO NÜMERO DE PONTOS SOLDADOS EM CHAPAS GALVANIZADAS /I. TURETTA - versão corr. São Paulo, 2016 $85 \mathrm{p}$.

Dissertação (Mestrado) - Escola Politécnica da Universidade de São Paulo. Departamento de Engenharia Metalúrgica e de Materiais.

1.Eletrodo de cobre. 2 Soldagem por resistência elétrica. 3. Aço Galvanizado. 4.Desgaste de eletrodo. I. Universidade de São Paulo. Escola Politécnica. Departamento de Engenharia Metalúrgica e de Materiais II.t. 
"Que os nossos esforços desafiem sempre as impossibilidades. Lembrai-vos de que as grandes proezas da história foram todas conquistas do que parecia impossível".

Charles Chaplin. 


\section{DEDICATÓRIA}

Dedico este trabalho aos meus pais e a todos aqueles que não tiveram a oportunidade de estudar. Que o mundo seja um lugar melhor para as próximas gerações. 


\section{AGRADECIMENTOS}

\section{A Deus.}

A minha família pelo incentivo permanente, pela paciência e compreensão.

Ao meu orientador Prof. Dr. Cláudio Geraldo Schön pela sua orientação, amizade, paciência e pelas importantes informações recebidas durante o desenvolvimento deste trabalho.

Ao Prof. Dr. Sérgio Duarte Brandi pela oportunidade e incentivo ao meu mestrado, pela sua imensa contribuição nas disciplinas e no desenvolvimento deste trabalho.

A todos os professores da Escola Politécnica da Universidade de São Paulo pelo apoio e dedicação, incentivadores do conhecimento e formadores de profissionais de qualidade para este país.

Ao Prof. Dr. Hugo Ricardo Zschommler Sandim e ao Dr. Kahl Zilnyk da Escola de Engenharia de Lorena EEL-USP pelo apoio a realização deste trabalho.

Ao Prof. Dr. Afonso Reguly da Escola de Engenharia DEMET-UFRGS pelo apoio a realização deste trabalho.

Aos colegas da Escola Politécnica, Jaime Casanova Soeiro Jr, Rafael Rocha Maia, José Veríssimo dos Santos e Luis Rodrigues pelo apoio e incentivo.

Ao IPT Instituto de Pesquisas Tecnológicas pelo apoio e incentivo a realização deste trabalho.

A Mitsubishi Motors Corporation pela oportunidade de realização do mestrado e pela disponibilidade das amostras e informações.

Ao amigo Antônio Carlos Aldrovandi pelo apoio e troca de informações importantes durante a realização deste trabalho.

Ao amigo Valdir Furlanetto pelo apoio e troca de informações importantes durante a realização deste trabalho.

Aos gestores da Mitsubishi Motors Juliano Lopes, Eduardo Thiago Costa, Edevaldo Totino, Marcelo Almeida e da Suzuki Motors Edenilson Ducatti, Hideaki Wada, Luiz Rosenfeld, Renato S. Pereira e tantos outros que incentivaram este trabalho.

A todos os amigos que participaram direta ou indiretamente desta importante conquista. 


\section{RESUMO}

O processo de soldagem por resistência de chapas galvanizadas automotivas é parte indispensável na concepção de uma carroceria de automóvel. Utilizado na união das chapas metálicas que formam um veículo, a grande importância deste processo deve-se basicamente ao fato de não agregar peso à carroceria, ter um desempenho satisfatório em relação à qualidade e produtividade nas linhas de montagem e ainda não onerar o custo final do produto, visto que seu custo de operação pode ser considerado baixo de modo geral. As variáveis específicas deste processo demandam atenção permanente quanto aos parâmetros dos equipamentos, a limpeza e a manutenção, a refrigeração dos eletrodos, a dressagem e a eliminação da camada de latão formada na superfície de contato entre o eletrodo e a chapa. A durabilidade e o desgaste do eletrodo estão ligados basicamente a estes cuidados, podendo ainda gerar ganhos em produtividade e qualidade do ponto além de reduzir o nível de problemas durante e após a soldagem da chapa. Durante a realização deste trabalho, procurou-se avaliar o comportamento do eletrodo fabricado através da liga Cu-Zr, o desgaste do eletrodo em relação ao número de pontos soldados, sua relação com a dureza e variação de temperatura durante o processo, os cuidados que podem retardar o desgaste e a microestrutura do material ao longo do número de pontos e do desgaste deste eletrodo.

Palavras-chave: Soldagem por resistência a ponto. Eletrodos de cobre liga Cu-Zr. Chapas galvanizadas. Desgaste de eletrodo. 


\begin{abstract}
The resistance welding process of automotive galvanized steel is an indispensable part in the design of a body car. Used in the union of the metal plates that form a vehicle, the great importance of this process is basically due to the fact not add weight to the body, have a satisfactory performance in relation to quality and productivity in assembly lines and still does not burden the final cost the product, the operating cost can be considered low in general. The specific variables this process require constant attention regarding the parameters of the equipment, cleaning and maintenance, cooling the electrodes, the dressing and the elimination of the brass layer formed on the contact surface between the electrode and the plate. The durability and the electrode wear are basically related to such care, and may generate gains in productivity and quality of point and reduce the level of problems during and after welding the plate. During this work, we tried to evaluate the electrode manufactured by $\mathrm{Cu}-\mathrm{Zr}$ alloy, the electrode wear in relation to the number of welding points, their relationship with the hardness and temperature variation during the process, the care can slow the wear and the microstructure of the material during the number of welding points and the wear of this electrode.
\end{abstract}

Keywords: Copper Electrodes. Resistance welding. Galvanized steel. Wear of the electrodes. 


\section{LISTA DE FIGURAS:}

Figura 1 - Mitsubishi L200 Triton GLX ...................................................17

Figura 2 - Funcionamento do processo de soldagem a ponto por resistência .......19

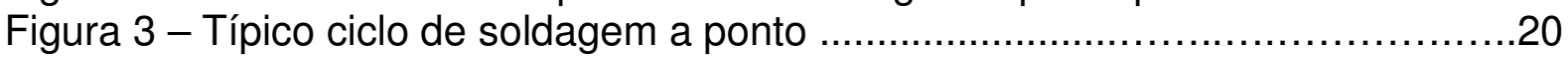

Figura 4 - Início da fusão das chapas de aço galvanizadas ...........................21

Figura 5 - llustração esquemática das resistências elétricas ...........................24

Figura 6 - Gradientes de temperatura de soldagem a ponto ..............................26

Figura 7 - Variação da resistência de contato com a pressão de contato ...............28

Figura 8 - Representação esquemática dos parâmetros elétricos durante a solda de

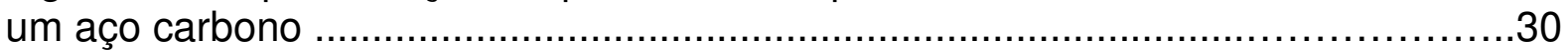

Figura 9 - Curva de resistência dinâmica teórica …….......................................31

Figura 10 - A sequência do processo de soldagem a ponto ...........................33

Figura 11 - llustração do ensaio de destacamento e medição do ponto de solda .....46

Figura 12 - Métodos de ensaio por ultrassom …..........................................48

Figura 13 - Formatos dos principais tipos de eletrodos …..........................56

Figura 14 - Modelo comparativo de eletrodos, irregular e normal ......................61

Figura 15 - Exemplo de avaliação do consumo de três tipos de eletrodos ................62

Figura 16 - Modelo de gabarito para verificação da vida útil do eletrodo ....................62

Figura 17 - Diagrama de soldabilidade ........................................................64

Figura 18 - Modificação da estrutura e das propriedades nas fases ........................66

Figura 19 - Detalhamento da condutividade do Z-Trode ......................................68

Figura 20 - llustração esquemática do modelo de eletrodo utilizado .......................69

Figura 21 - llustração esquemática da linha de soldagem da L200 Triton ................70

Figura 22 - Mapa de dureza das amostras de eletrodos ......................................72

Figura 23 - Micrografia óptica da amostra "como concebido" (a) perto da ponta do eletrodo, submetido a cloreto férrico e (b) detalhe da região de transição entre as regiões axialmente alinhadas e não alinhadas axialmente da amostra ....................73

Figura 24 - Danos perto da ponta do eletrodo amostra 1 ....................................74

Figura 25 - Danos perto da ponta do eletrodo amostra 2 ...................................75

Figura 26 - Danos perto da ponta do eletrodo amostra 3 ...................................75

Figura 27 - Danos perto da ponta do eletrodo amostra 4 (a) vista geral da camada de "latão" e (b) detalhe da estrutura de deformação perto da ponta do eletrodo ...........76 Figura 28 - Detalhe do diagrama de fase $\mathrm{Cu}-\mathrm{Zn}$ na região de estabilidade da fase 77 Figura 29 - Detalhes da amostra 5 (6000 pontos) (a) aspecto geral da camada de "latão" e (b) exemplo de interação entre precipitados de zircônio e precipitados ricos em oxigênio 78

Figura 30 - Gráfico da área da seção transversal do eletrodo x número de pontos soldados 


\section{LISTA DE TABELAS:}

Tabela 1 - Itens básicos para inspeção visual na soldagem a ponto 49

Tabela 2 - Principais tipos e características de aços galvanizados automotivos .....50

Tabela 3 - Características dos materiais dos eletrodos .....................................55

Tabela 4 - Principais características dos eletrodos conforme formatos ...................56

Tabela 5 - Frequência teórica recomenda para fresagem confome material ...........60

Tabela 6 - Identificação das amostras e o número aproximado de pontos …............71

Tabela 7 - Área da seção transversal de acordo com número de pontos soldados 79

Tabela 8 - Estudo comparativo. Dressagem com lima x Dressagem mecanizada ..80 


\section{LISTA DE ABREVIATURAS E SIGLAS:}

CA: Corrente Alternada.

CC: Corrente Contínua.

Es: Energia elétrica dinâmica entre eletrodos.

EDS: Espectroscopia por Dispersão de Energia.

Is: Corrente instantânea de soldagem.

Is RMS: Corrente de soldagem eficaz.

IACS International Annealing Copper Standard

MEV: Microscópio Eletrônico de Varredura.

RMS: Root Mean Square.

ZAC: Zona Afetada pelo Calor 


\section{LISTA DE SÍMBOLOS:}

$\begin{array}{lll}\text { Q } & \text { Calor gerado na soldagem } & (\mathrm{J}) \\ \mathrm{E} & \text { Módulo de elasticidade } & (\mathrm{MPa}) \\ \mathrm{I} & \text { Intensidade de Corrente de Solda } & (\mathrm{A}) \\ \mathrm{R} & \text { Resistência elétrica - Ohm. } & (\Omega) \\ \mathrm{e} & \text { Espessura de chapa } & (\mathrm{mm}) \\ \sigma & \text { Tensão aplicada } & (\mathrm{MPa}) \\ \mathrm{t} & \text { Tempo de aplicação da corrente } & (\mathrm{ciclos}) \\ \rho: & \text { Densidade. } & \left(\mathrm{Kg} / \mathrm{m}^{3}\right. \\ \beta: & \text { Beta. } & \\ \alpha: & \text { Alfa. } & \\ \mu: & \text { Mícron. } & \end{array}$




\section{SUMÁRIO}

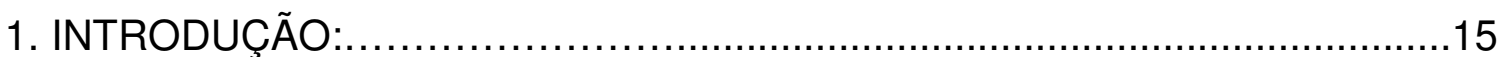

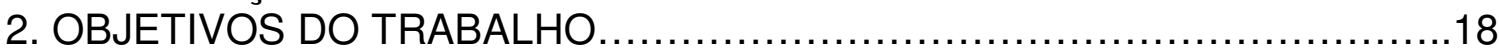

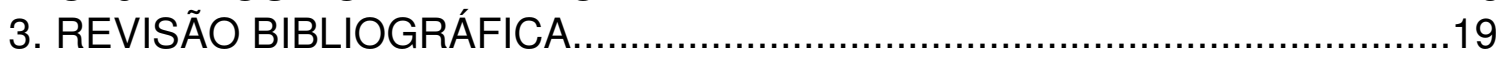

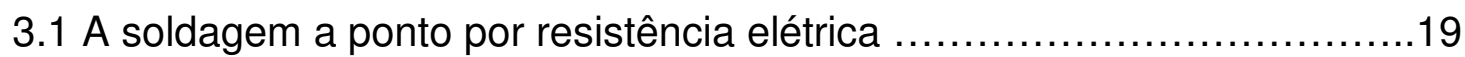

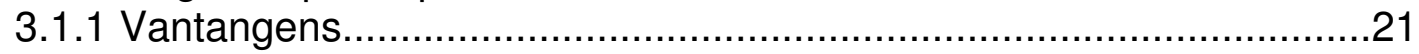

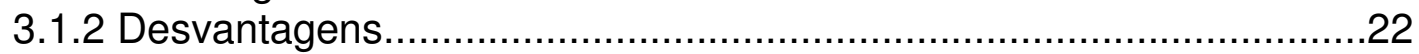

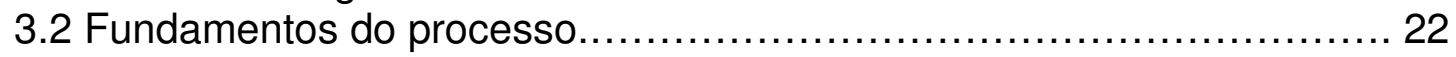

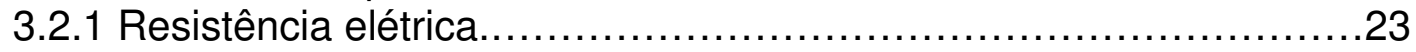

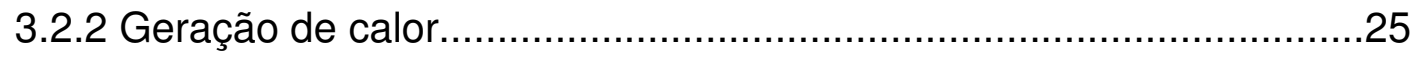

3.2.3 Resistências de contato............................................................27

3.2.4 Resistência dinâmica de contato...................................................27

3.3 Sequencia do processo de soldagem a ponto......................................32

3.4 Parametros de soldagem a ponto....................................................33

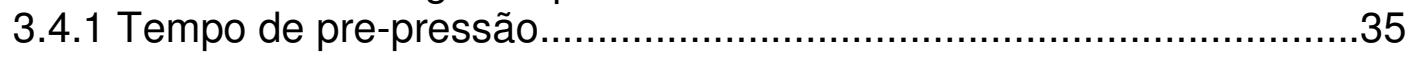

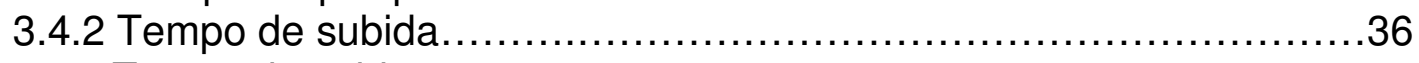

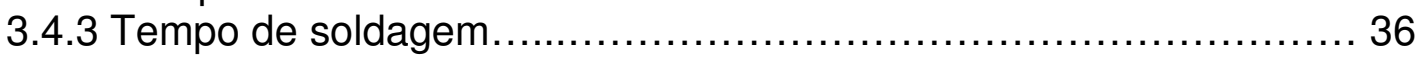

3.4.4 Tempo de descida................................................ 36

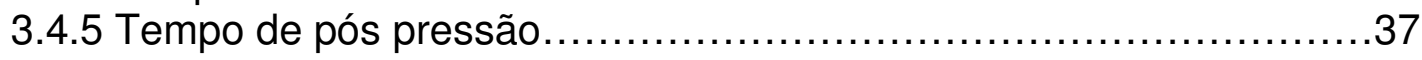

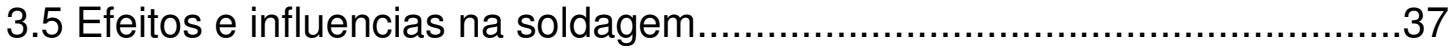

3.5.1 Efeitos dos tempos iniciais do processo...................................... 38

3.5.2 Efeitos da força de soldagem. ............................................... 38

3.5.3 Efeitos dos tempos de soldagem. ........................................ 38

3.5.4 Efeitos do tempo de resfriamento.......................................... 39

3.5.5 Efeitos das condicoes superficiais e revestimento. ........................ 39

3.5.6 Influência dos eletrodos.........................................41

3.6 Problemas operacionais durante o processo ................................... 41

3.6.1 Desvios de corrente ............................................................. 41

3.6.2 Indentação excessiva ........................................................ 42

3.6.3 Distribuição da corrente .................................................... 42

3.6.4 Alinhamento e desalinhamento de eletrodos ............................. 43

3.6.5 Expulsão de material.......................................................... 43

3.7. Ensaios e métodos de controle de qualidade da solda .........................44

3.7.1 Ensaio por destacamento .....................................44

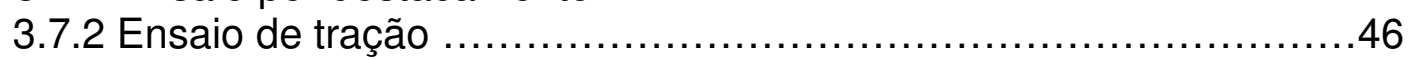

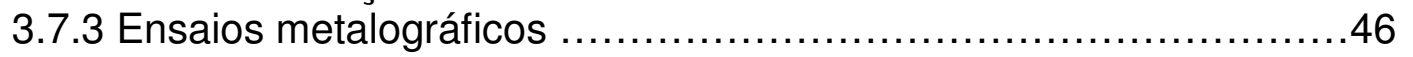

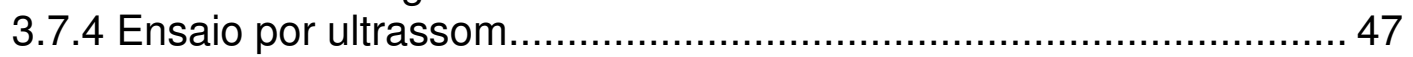

3.8 Os aços galvanizados automotivos ............................... 50

3.8.1 Aços galvanizados por eletrodeposição .................................... 50

3.8.2 Aços galvanizados por imersão a quente ..................................... 51

3.8.3 Soldabilidade de aços revestidos e não revestidos....................... 52

3.9 O eletrodo de soldagem a ponto ................................................... 53

3.9.1 Características dos materiais para eletrodos ......................54

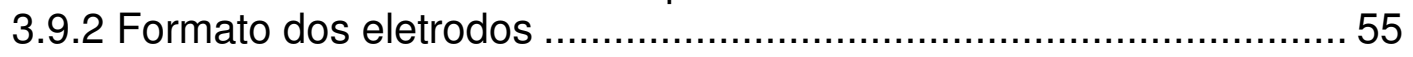

3.9.3 Desgaste dos eletrodos................................................. 57

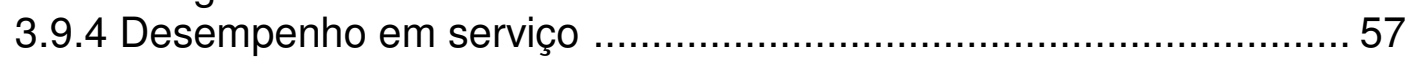

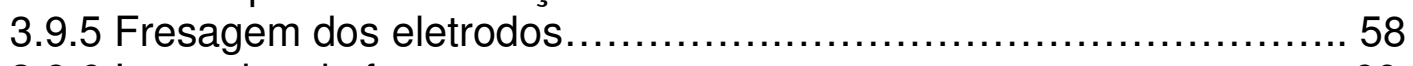

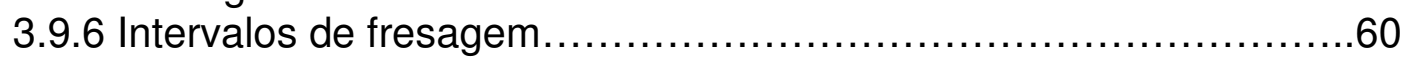




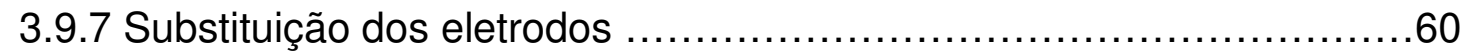

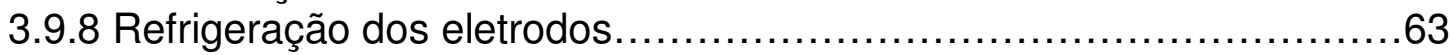

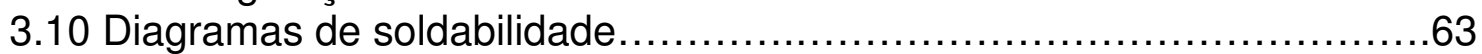

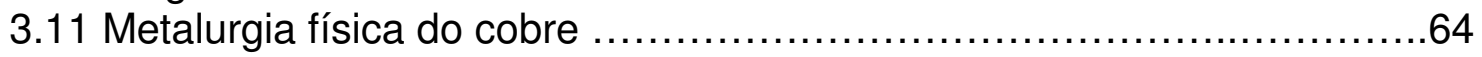

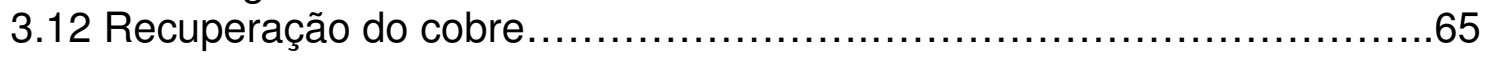

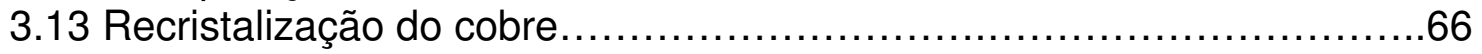

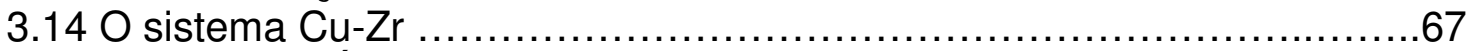

4. MATERIAIS E MÉTODOS...................................................69

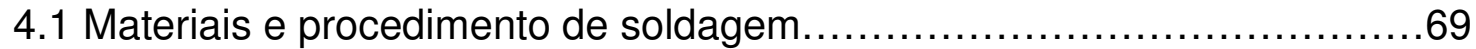

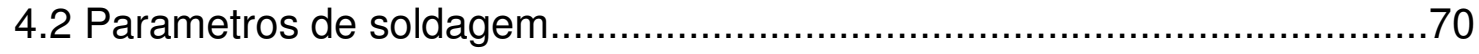

4.3 Caracterização das amostras................................................................

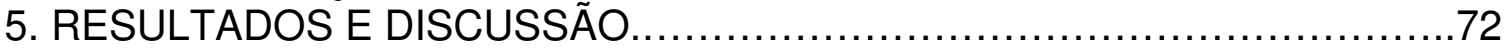

5.1 Análises de dureza e micrografias ópticas ...............................72

5.2 Análise da correlação entre área do eletrodo versus número de pontos ...79

5.3 Estudo comparativo dos processos de fresagem ............................ 80

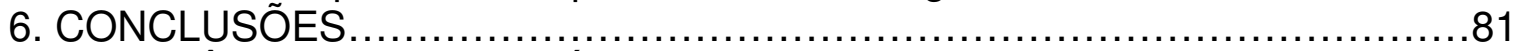

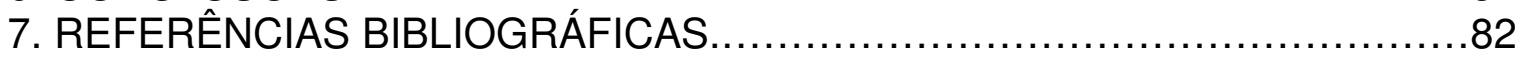




\section{INTRODUÇÃO}

A soldagem é o processo de união entre duas partes metálicas, usando uma fonte de calor, com ou sem aplicação de pressão, onde a solda, é o resultado desse processo. [1]

A soldagem a ponto por resistência elétrica é o principal processo utilizado para a união de chapas metálicas em uma linha de montagem de automóveis, em inglês é definida pela sigla RSW, Resistance Spot Welding.

Durante o processo de soldagem por resistência, duas chapas finas de metal, sofrem um elevado aquecimento na área de contato entre ambas através da aplicação de corrente elétrica e pressão nesta área, a relação entre o calor gerado na região e a corrente elétrica que passa pelo sistema em um determinado tempo, é chamada de efeito Joule, o aquecimento dessa região leva a fusão do material metálico.

A soldagem por resistência elétrica emprega um determinado tipo de eletrodo, comumente chamado de "capa". O eletrodo possui geometria particular que através do contato entre as chapas e as duas extremidades formam uma pequena região fundida de material, essa região fundida é o que chamamos de ponto. Este ponto formado é originado com diâmetro característico de acordo com o estado em que a extremidade da capa se encontra no momento do contato.

A qualidade das juntas soldadas é definida pelas tensões de compressão que são mantidas durante e após o aquecimento, aliadas a corrente operacional e a geometria dos eletrodos. [2].

A temperatura ideal para que haja uma fusão adequada do ponto de solda em uma chapa de aço é da ordem de $1.300^{\circ} \mathrm{C}$ no núcleo da solda, na superfície da chapa em contato com o eletrodo deve atingir no máximo $900^{\circ} \mathrm{C}$ para que a estrutura do material não seja alterada, gerando neste caso um enfraquecimento da sua estrutura granular. [3]

Através de simulações e experimentos, foram verificadas temperaturas entre 750 e $850{ }^{\circ} \mathrm{C}$ (1023 a $1123 \mathrm{~K}$ ) próximo as extremidades do eletrodo durante o processo de soldagem. A combinação entre essas temperaturas e as tensões de compressão podem gerar solicitações de fadiga termo mecânicas em serviço. [4]

Além disso, as altas correntes elétricas podem gerar modificações na estrutura, recuperação e recristalização do cobre. [5] 
Além da alta temperatura envolvida no processo, a pressão que os eletrodos exercem, servem para garantir a transferência da corrente e consequente geração do ponto na chapa. Apesar de serem refrigerados a água, além dos eletrodos que estão sujeitos a altas temperaturas, as peças também estão sujeitas a tensões de compressão e poderão sofrer degradação em serviço.

É possível descrever de forma sequencial o processo de soldagem a ponto por resistência elétrica, considerando cada etapa, da seguinte forma:

- Contato dos eletrodos com as chapas;

- Pressão dos eletrodos nas chapas;

- Ativação da corrente elétrica que circula no sistema pelo tempo necessário para gerar fusão do material;

- Interrupção da corrente elétrica, porém, com pressão contínua dos eletrodos nas chapas até que ocorra a solidificação do metal;

- Contato dos eletrodos é interrompido e os eletrodos são retraídos para dar início ao um novo ponto de soldagem. [6]

As capas de eletrodos são utilizadas em larga escala na indústria automotiva, estima-se que para a soldagem de um automóvel leve, são utilizados entre 4.000 a 5.000 pontos de solda.

Em razão do elevado número de pontos de solda, aliada as condições de trabalho a que são submetidas, as capas de eletrodo sofrem um significativo desgaste, e também passam por uma relativa e progressiva deformação na estrutura do material ao longo da sua vida útil. Os parâmetros de soldagem são parte importante no processo de desgaste das capas de eletrodo.

A manutenção da qualidade do eletrodo é vital para efeitos de projeto, uma vez que as peças montadas são sujeitas a cargas dinâmicas graves. [7]

Durante a vida de um eletrodo típico em serviço, ele é submetido a operações de usinagem chamadas dressagem, que removem a parte do material degradado e restaura a geometria da ponta do eletrodo.

Estas operações aliadas a substituições do eletrodo, prejudicam a alta produtividade do processo, e, portanto, grandes esforços são dedicados na compreensão e controle do processo de degradação da ponta do eletrodo. 
O uso de chapas de aço revestidas em zinco aumentou significativamente ao longo das últimas décadas devido a sua boa resistência a corrosão e custo relativamente baixo.

Na soldagem de chapas de aço galvanizado, surge um agravante adicional que é o baixo ponto de fusão do zinco com rápida difusão para dentro da matriz de cobre, produzindo uma camada rica em zinco (solução sólida Cu-Zn) que aumenta o desgaste da ponta do eletrodo.

Conforme estudo realizado por Guedes et al. [8], o desgaste do eletrodo influencia a corrente de soldagem de tal modo que há uma queda progressiva da corrente em razão do aumento no número de pontos soldados. Embora o rápido avanço tecnológico em todos os processos disponíveis, percebe-se um avanço muito lento na busca de dados aprofundados a respeito do desgaste das capas.

O modelo de veículo utilizado para soldagem com os eletrodos é a pick-up Mitsubishi L200 Triton, plataforma CR47, sendo esta, a pick-up mais popular da Mitsubishi Motors no mundo. Este modelo de veículo é produzido nas versões HPE Diesel AT, HPE Diesel MT, HPE Flex AT, GLS, GLX, HLS, Savana.

O modelo estreou no mercado em 1978, com o nome de Mitsubishi Forte, o modelo atual disponível no mercado, refere-se à quarta geração e foi projetada por Akinori Nakanishi, tendo sido lançada em 2005.

Atualmente é montada na Tailândia e exportada para mais de 140 países, o modelo também é fabricado no Brasil através da subsidiária brasileira na fábrica de Catalão GO.

A produção nacional do modelo estreou em 2006, atualmente possui modelo de carroceria com 2 portas com cabine simples e sistema de tração 4WD/2WD, 2 portas com cabine club e sistema de tração $4 W D / 2 W D, 4$ portas com cabine dupla 4WD/2WD com motorização 2.500 DI-D. A Figura 1 ilustra o modelo da pick-up.

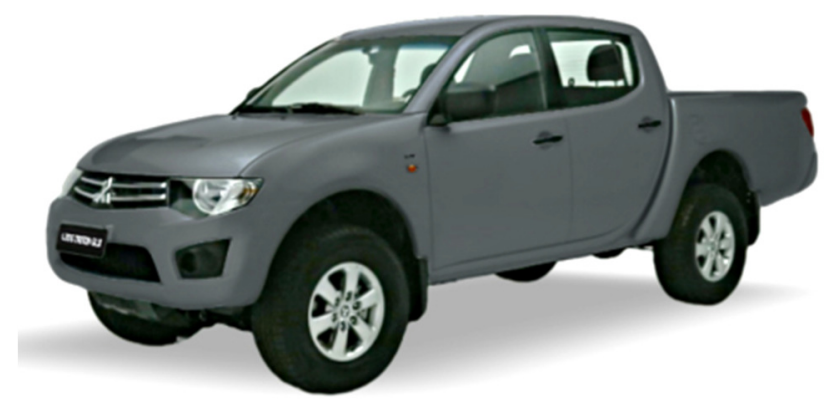

Figura 1 - Mitsubishi L200 Triton GLX [Autor] 


\section{OBJETIVOS DO TRABALHO}

O objetivo geral deste trabalho é estudar o comportamento e o desgaste do eletrodo para soldagem a ponto por resistência elétrica de liga Cu-Zr utilizado na soldagem de chapas galvanizadas automotivas com espessura de $0,75 \mathrm{~mm}$ revestidas com camada de $12 \mu \mathrm{m}$ a $15 \mu \mathrm{m}$ de $\mathrm{Zn}$ na superfície.

O objetivo específico do presente trabalho é caracterizar as mudanças microestruturais que ocorrem nos eletrodos para soldagem a ponto por resistência elétrica utilizados na soldagem de uma caminhonete modelo pick-up, através do mapeamento de dureza e imagens de elétrons retroespalhados (BSE) para investigação da microestrutura de deformação das amostras. Os precipitados são identificados pela sua composição e medidos utilizando espectroscopia por dispersão de energia de elétrons (EDS). 


\section{REVISÃO BIBLIOGRÁFICA}

\subsection{A soldagem a ponto por resistência elétrica.}

A junção de duas peças através da soldagem por resistência se dá por meio da geração de calor devido a passagem da corrente elétrica e da aplicação de pressão, onde, durante este processo, as peças se aquecem e ocorre a fusão localizada no ponto de contato na superfície de separação entre ambas. [1]

A soldagem por resistência elétrica é um dos processos mais utilizados na união de chapas de espessuras variadas e diferentes tipos de materiais, este processo é aplicado principalmente na indústria automotiva na soldagem de carrocerias de automóveis e na chamada linha branca na fabricação de eletrodomésticos. [6]

A Figura 02 ilustra o princípio de funcionamento do processo de soldagem a ponto por resistência elétrica.

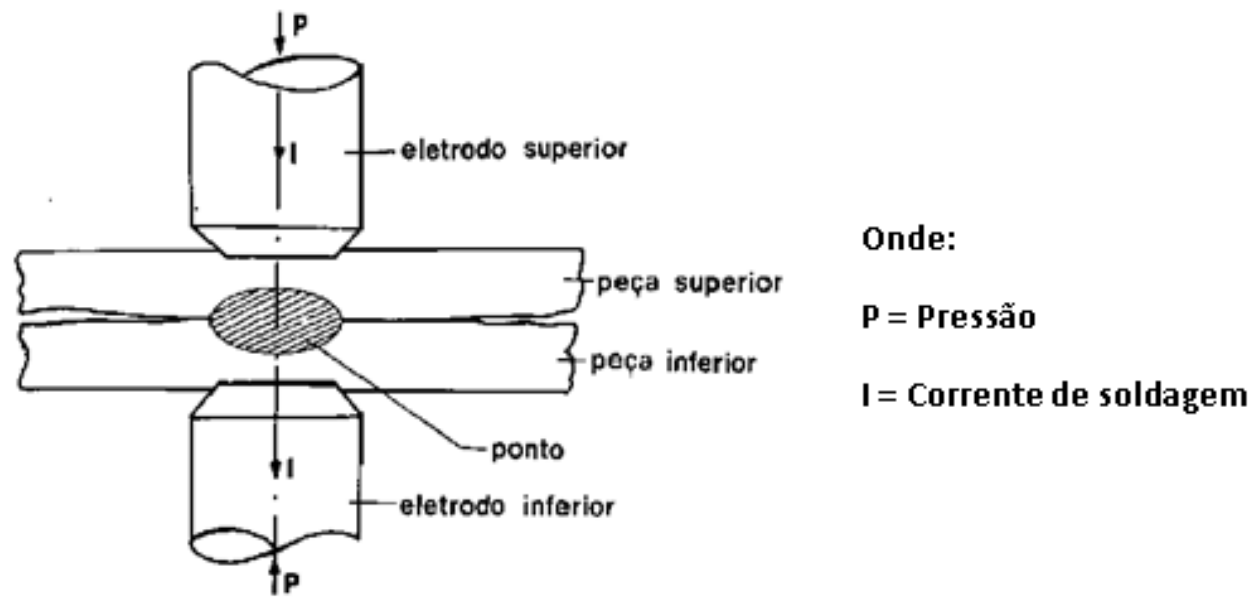

Figura 02 - Funcionamento do processo de soldagem a ponto por resistência [1]

Para a realização de um ponto de solda é necessário inicialmente, um equipamento adequado, responsável por realizar o ponto de solda a que se pretende obter neste processo, o equipamento também denominado como máquina de solda, pode ser do tipo estacionário ou do tipo suspenso que requer o uso de pinças de solda.

A forma construtiva e de operação dos dois equipamentos são diferentes, porém seguem o mesmo princípio de funcionamento e padrões de regulagem.

O modelo de máquina do tipo suspenso é o mais empregado normalmente neste processo, pois permite maior facilidade de acesso as áreas complexas. 
As máquinas utilizadas no processo de soldagem por resistência elétrica são compostas por três elementos: Circuito de controle, Sistema mecânico, Circuito elétrico.

Quando a passagem de corrente elétrica é cessada, é mantida a força de aplicação nos eletrodos enquanto ocorre o resfriamento do metal e a solidificação do metal de solda, os eletrodos são então retraídos após a formação do ponto de solda. O diâmetro do ponto de solda é definido pela área da face do eletrodo.

As tensões envolvidas no processo variam entre 1 a $20 \mathrm{~V}$, raramente alcançam cerca de $30 \mathrm{~V}$, onde o tempo de aplicação da corrente varia entre menos de 0,01 s para chapas muito finas ou vários segundos para chapas mais grossas. [7]

A corrente elétrica utilizada na soldagem por resistência é fornecida usualmente por um transformador, esse transformador é responsável por transformar a corrente de alta voltagem e baixa amperagem para uma corrente de baixa voltagem e alta amperagem. [10]

O tempo de soldagem pode ser definido como o tempo de passagem da corrente na junta a ser soldada, usualmente, esse tempo é expressado em ciclos.

Os tempos de soldagem variam de acordo com a complexidade e necessidade, são recomendados períodos curtos quando se busca boa produtividade e redução nos efeitos da ZAC na região, e períodos mais longos para finalidades especificas. [11]

Um ciclo de soldagem representa a combinação entre a corrente de soldagem, a força nos eletrodos e o tempo de aplicação, essa combinação é responsável pelo resultado final da qualidade da solda. A Figura 03 ilustra um típico ciclo de soldagem.

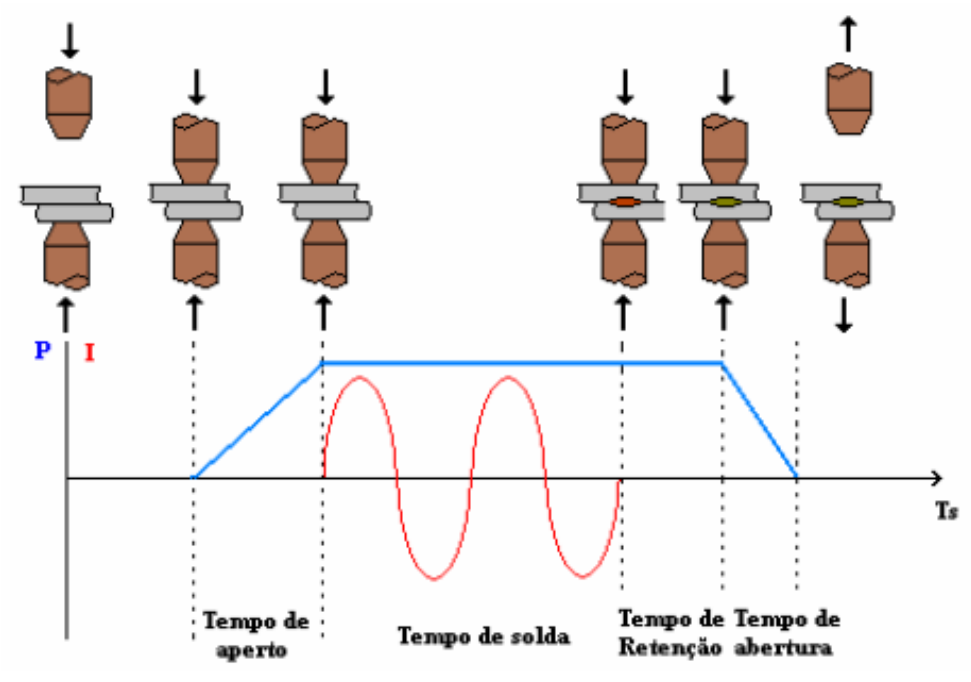

Figura 03 - Típico ciclo de soldagem a ponto [4] 
Um ponto de solda deverá ter sido gerado ao final de um ciclo completo de soldagem, a alteração da resistência pode afetar a formação do ponto de solda que assume o formato esférico característico da extremidade do eletrodo caso tenha sido transferido calor suficiente dentro do processo. [12]

Quando o calor transferido durante o processo é insuficiente para fundir completamente toda a área de solda, pontos podem ser gerados com algum tipo de defeito não totalmente aparente e à medida que o eletrodo se degrada, a densidade de corrente diminui, produzindo pontos irregulares. [12]

A Figura 04 mostra a formação de um ponto de solda entre duas chapas de aço galvanizado, primeiro ocorre o derretimento do revestimento da chapa, em seguida o aquecimento e consequente fusão do material.

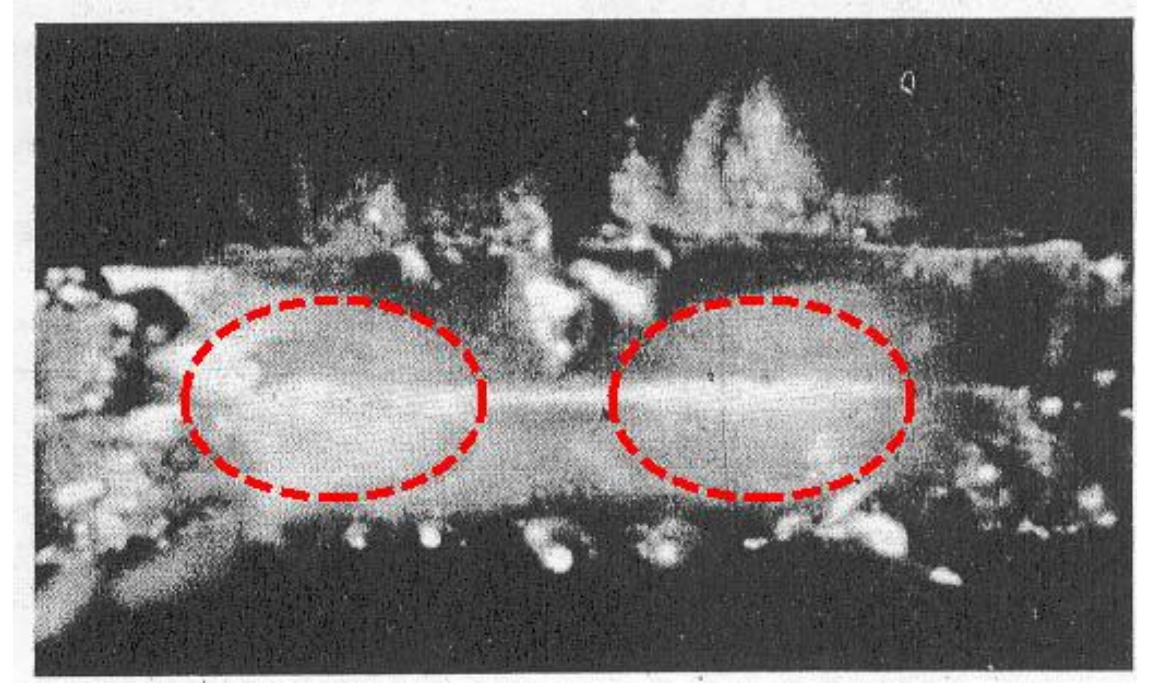

Figura 04 - Início da fusão das chapas de aço galvanizadas [12]

\subsubsection{Vantagens}

É possível elencarmos diversas vantagens do processo de soldagem a ponto por resistência, entre as principais delas, destacam-se:

- A produtividade, onde podem ser realizados vários pontos de solda em um intervalo de tempo curto;

- O baixo custo de operação desse processo, sendo que cada ponto de solda custa cerca de centavos; 
- É um processo considerado simples e não demanda tanta qualificação e habilidade por parte do operador do equipamento;

- O ponto de solda também não requer nenhum tipo de acabamento já que não gera resíduo ou escória de solda durante processo.

- O processo permite a união de mais de duas chapas, mesmo com espessuras e composições químicas diferentes.

Outra vantagem interessante que pode ser destacada, é o fato deste processo não demandar a adição de material de solda, já que o ponto é gerado através da fusão das chapas, o que não agrega peso a carroceria. [6]

Na indústria automobilística, o peso final do automóvel é motivo de atenção constante.

\subsubsection{Desvantagens}

Embora apresente muitas vantagens, o processo também possui certas desvantagens e limitações, entre as principais desvantagens podemos citar que:

- Dificilmente consegue-se desmontar as peças soldadas sem que haja dano ao conjunto soldado;

- Os equipamentos utilizados neste processo são geralmente mais caros quando comparados a outros processos de solda;

- Metais diferentes só poderão ser soldados quando suscetíveis a formação de uma liga ou quando adicionado algum material que pode formar liga com metal base;

- Os limites de resistência a tração e a fadiga deste processo são relativamente baixos devido ao entalhe entre as chapas soldadas.

Por se tratar de um processo especifico, é importante uma análise prévia para avaliar as suas limitações quanto aos materiais e produtos a serem soldados. [6]

\subsection{Fundamentos do processo}

O ponto de solda é gerado através do contato elétrico dos eletrodos que são ligados a uma fonte de tensão e posicionados em contato com a chapa para gerar a união entre elas através da fusão do material. 
Como a intensidade de corrente elétrica utilizada na soldagem de aços galvanizados é muito alta, é necessário que haja um sistema de resfriamento eficiente, do contrário, pode ocasionar um superaquecimento dos eletrodos.

Alguns processos alternativos podem ser implementados antes do início da soldagem de chapas, como o aquecimento das chapas de aço que serão soldadas, porém este tipo de ação demanda maior estrutura de equipamentos e pessoas.

O processo de solda a ponto pode ser muito bem empregado para espessuras de até 3,5 mm, ocasionalmente alcançam 6,5 $\mathrm{mm}$ de espessura, o processo pode ser empregado também para soldar espessuras maiores, porém dependem da utilização de equipamentos apropriados para tal atividade. [6]

Os parâmetros de soldagem também são fatores importantíssimos que devem ser considerados no processo, pois interferem de forma direta no resultado e na qualidade final do ponto de solda. [13]

\subsubsection{Resistência elétrica}

A resistência elétrica é definida como a oposição a passagem da corrente elétrica através de um meio condutor, a sua intensidade é medida em Ohms $(\Omega)$. O calor gerado pelo efeito Joule e responsável pela união das chapas metálicas durante o processo de soldagem a ponto por resistência elétrica, depende diretamente da corrente elétrica, da resistência elétrica e do tempo de soldagem medido em $\mathrm{s}$.

As resistências elétricas envolvidas em todo o circuito são importantes devido as elevadas correntes de soldagem necessárias para que haja a fusão.

A resistência elétrica no circuito da corrente é o principal fator que controla a soldagem, pois a resistência elétrica define os valores e a necessidade de demanda para outros parâmetros envolvidos no processo.

A soma de todas as resistências do circuito por onde passa a corrente, gera a resistência total do circuito, que pode ser definido como um conjunto de cinco resistências elétricas que se conectam em série são responsáveis pelo aquecimento da junta. A soma das resistências do circuito, é expressa através da Equação 1.

$$
R T=R 1+R 2+R 3+R 4+R 5
$$


Onde:

R1 = Resistência entre o eletrodo superior e a chapa superior;

R2 = Resistência da chapa superior;

R3 = Resistência de interface entre as chapas;

R4 = Resistência da chapa inferior:

R5 = Resistência entre o eletrodo inferior e a chapa inferior.

A resistência de interface entre as chapas soldadas $\mathrm{R} 3$ está ligada diretamente as condições da superfície das chapas, a força e ao contato do eletrodo.

As resistências das chapas inferior e superior são praticamente desprezíveis na fase inicial da soldagem, mas devem ser consideradas nos estágios finais do processo. De modo geral, as resistências de contato são mais importantes na geração de calor durante o processo de soldagem por resistência do que as resistências das peças a serem soldadas. [1]

O valor da resistência elétrica na interface entre as chapas metálicas se situa geralmente no intervalo entre 50 a $500 \mu \Omega$, porém pode ser tão baixa quanto $20 \mu \Omega$, que é o caso do alumínio, sendo necessário correntes com intensidade entre 5000 e 1000.000 A para que ocorra a fusão do material, o que depende da condutividade térmica do metal envolvido na soldagem. A condutividade térmica do aço é baixa, mas é alta para o caso do alumínio. [7]

As resistências envolvidas neste processo, são melhor entendidas quando analisamos a Figura 5.

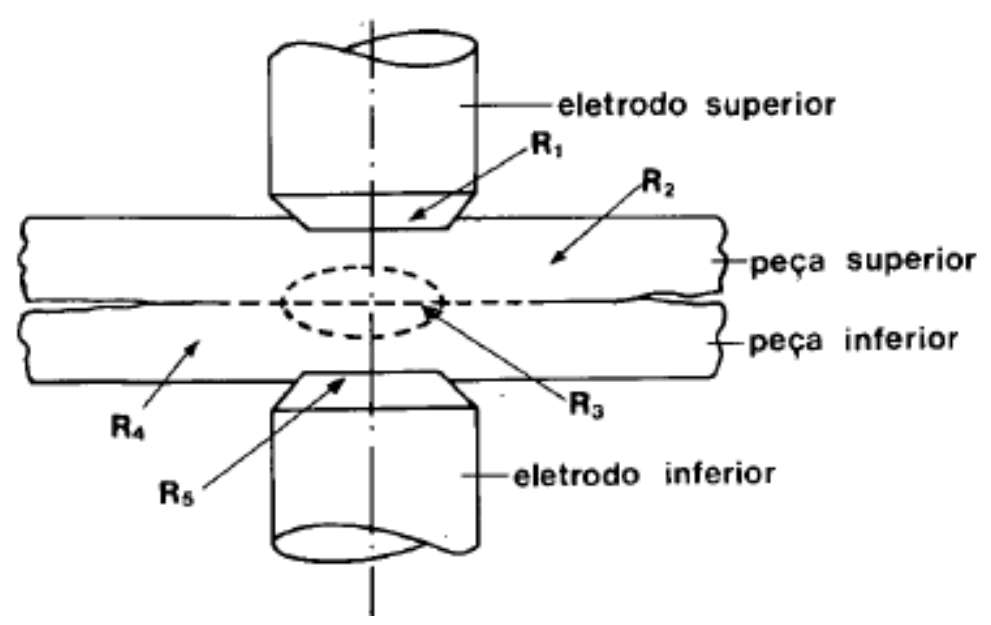

Figura 5. Ilustração esquemática das resistências elétricas [1] 
A resistência $\mathrm{R} 3$ é a que desempenha o papel mais importante no sistema, pois é nesta região que o ponto é formado, assim como a geração de calor necessária para a fusão do material.

As resistências entre os eletrodos superior com a chapa superior e eletrodo inferior com a chapa inferior, são consideradas para o caso de materiais de baixa resistividade elétrica, onde devem ser mantidas em valores baixos para evitar excesso na geração de calor e aumentar a vida útil dos eletrodos.

A resistência de contato na interface das chapas a serem soldadas é a fonte principal de aquecimento através do efeito Joule, no caso de metais de grande condutibilidade elétrica. A resistência varia de acordo com o tipo de superfície de contato, as superfícies lisas possuem uma resistência elétrica menor quando comparada a outras superfícies, onde a redução da força do eletrodo, aumenta a resistência. [11]

Caso não haja variação na resistividade de um material, é possível definir e criar um local de grande resistência, direcionando assim uma restrição a passagem da corrente entre as partes a serem soldadas, este procedimento é definido como concentração de corrente. [11]

O acabamento superficial das chapas interfere diretamente na resistência elétrica, pois há uma demanda diferente de pressão de acordo com a superfície, com o aumento da pressão há um contato mais uniforme entre as partes e isso faz com que ocorra uma diminuição da resistência elétrica e um aumento da circulação de corrente no sistema.

\subsubsection{Geração de calor}

A geração de calor se deve basicamente à resistência do conjunto à passagem de corrente elétrica de um eletrodo a outro, esse calor é retido na região do ponto onde alcança altas temperaturas, responsáveis pela fusão das chapas e a geração do ponto de solda.

Embora nem todo o calor gerado no sistema, seja utilizado para realizar a solda, uma parte desse calor é perdida no ambiente, outra parte se perde através da convecção, condução e radiação. [4] 
Embora ocorram todas essas perdas de calor, a quantidade de calor gerado na região de contato entre o eletrodo e as chapas é maior do que em qualquer outra região do circuito.

A quantidade de calor ou energia gerada em um condutor elétrico depende de alguns fatores principais, como:

- Corrente elétrica;

- Resistencia do condutor;

- Duração da corrente.

Esses fatores acabam afetando diretamente o calor ou energia gerada pelo sistema, essa energia pode ser obtida através da Equação 2:

$$
Q=\frac{r}{J} \int_{0}^{t} I^{2} \cdot R \cdot d t
$$

Onde:

$\mathrm{Q}=$ energia gerada, em $\mathrm{J}$;

$r=$ rendimento térmico, perdas por radiação e condução;

$\mathrm{J}=$ constante, 4,185 J;

I = corrente de soldagem, em A;

$\mathrm{R}=$ conjunto da resistência elétrica, em $\Omega$;

$\mathrm{t}$ = tempo de duração da corrente, em s.

A Figura 6 ilustra de forma esquemática os gradientes e a distribuição da temperatura durante o processo de soldagem por resistência, onde é verificado que a região fundida entre as chapas é uniforme após o aquecimento e fusão do material.

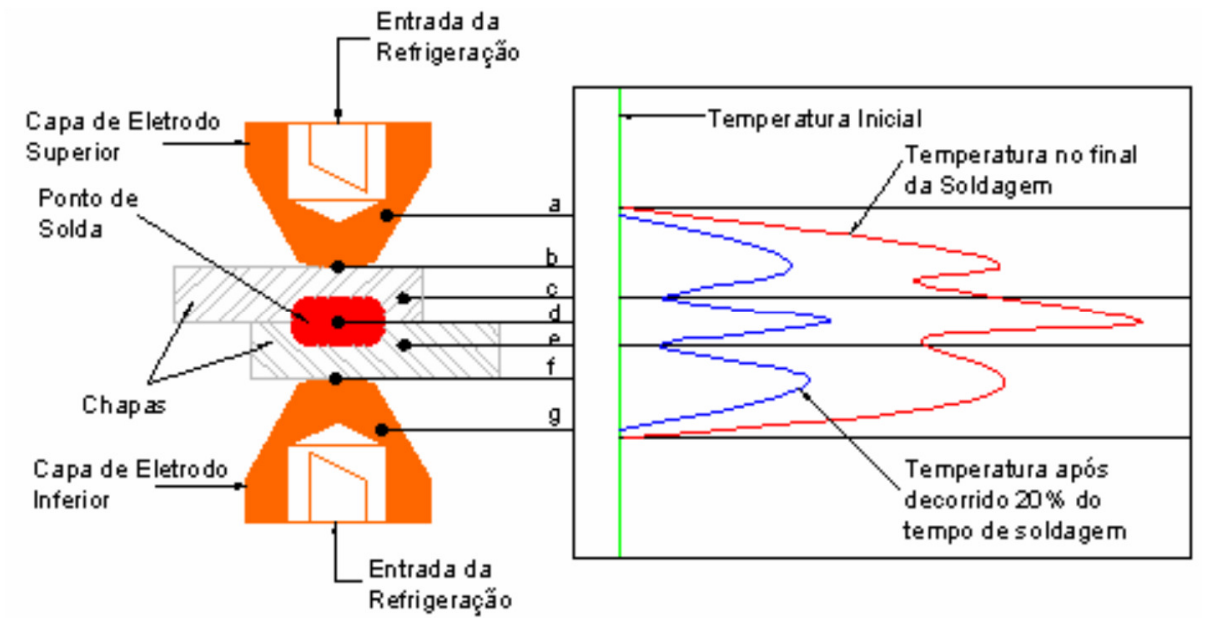

Figura 6 - Gradientes de temperatura de soldagem a ponto [4] 
A curva a esquerda da Figura 6 mostra o gradiente térmico no início da soldagem, a curva a direita da figura mostra o gradiente térmico no final da soldagem.

O calor é gerado em todos os pontos de resistência, onde a intensidade do calor gerado é dependente da resistência à passagem da corrente de soldagem. Um fator importante é a concentração de calor na interface do metal base, pois esse efeito irá minimizar o calor gerado nas outras regiões. Como a maior resistência estará localizada na região d, o calor será desenvolvido mais rapidamente neste local. [4]

Considerando-se a distribuição da temperatura nos pontos durante a soldagem, o tempo transcorrido e as perdas geradas, pode-se afirmar que para que a solda ocorra, a região de contato entre as chapas deve ser a primeira a atingir a temperatura de fusão dos metais base, em termos de rendimento, as soldas realizadas em tempos menores representam um melhor rendimento térmico no processo.

\subsubsection{Resistências de contato}

A resistência de contato presente na interface entre as chapas é a principal fonte de aquecimento através do efeito Joule, a resistência de contato depende diretamente da resistividade da camada de revestimento do material, da dureza superficial e também da limpeza da superfície.

A presença de impureza na superfície da chapa, faz com que a área de contato seja afetada e aumentem os valores das resistências elétricas na superfície de contato, elevando a intensidade da corrente, essas impurezas geralmente não são substancias condutoras.

Quanto mais baixos forem os valores da resistência elétrica, maior deverá ser a intensidade de corrente, porém vale destacar que a resistência elétrica varia com o tempo durante a soldagem.

O local de contato entre as chapas é onde ocorre a fusão do material e a geração do ponto, esta região é que apresenta a maior temperatura do sistema, devido a esta condição, os eletrodos de solda a ponto, são produzidos através de materiais com baixa resistência elétrica, em grande parte através de ligas a base de cobre, além da baixa resistência elétrica dos eletrodos, eles também apresentam facilidade de 
deformação, com isso, ocorre um melhor assentamento e ajuste do eletrodo na superfície da chapa.

A baixa resistência elétrica do material dos eletrodos, aliada a facilidade de deformação, reduzem a resistência elétrica na interface de contato, minimizando assim o calor gerado nestas regiões. [14]

A Figura 7 mostra a variação da resistência de contato em função da pressão de acordo com o diferente tipo de acabamento superficial das chapas.

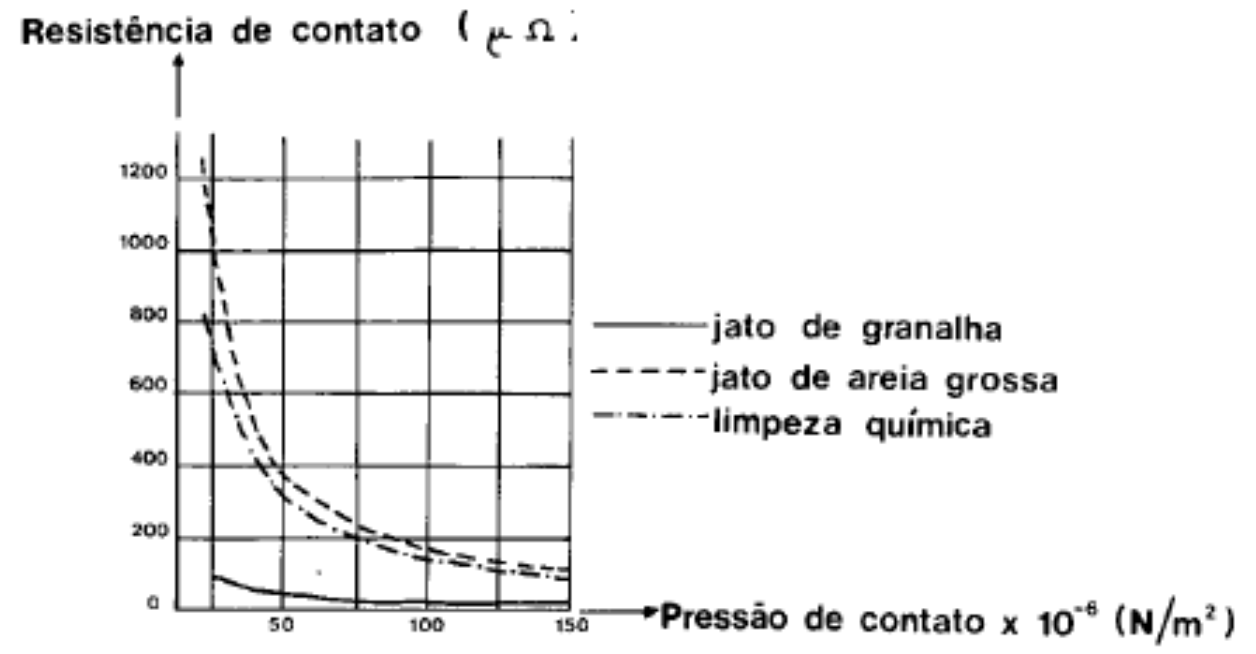

Figura 7. Variação da resistência de contato com a pressão de contato. [1]

Alguns estudos teóricos sobre resistência de contato, que foram complementados experimentalmente através de fatores de correção, mostram que para pressões entre 0,3 e 0,8 do limite de escoamento do material, a Equação 3 pode ser utilizada para se chegar ao valor da resistência de contato. [1]

$$
R=\frac{0,85 \cdot \rho \cdot \sqrt{Y}}{\sqrt{\pi \cdot n \cdot C p}}
$$

Onde:

$\mathrm{R}=$ resistência de contato, $(\mu \Omega)$

$\rho=$ resistividade elétrica dos materiais, $(\Omega \mathrm{m})$

$Y=$ limite de escoamento, $\left(\mathrm{kgf} / \mathrm{cm}^{2}\right)$

$\mathrm{n}=$ número de pontos por unidade de área,

$\mathrm{Cp}=$ porcentagem da área metálica condutora em contato. 
Entretanto, vale observar que a equação acima, é recomendada para chapas em aço com valores próximos ao limite de escoamento ou acima dele, pois deve-se considerar que a condutibilidade aumenta de forma aproximadamente linear com a pressão.

Para aplicação em outros tipos de metais, como no caso o alumínio, esta equação não é recomendada, possivelmente em razão da formação de óxidos de alumínio na camada superficial das chapas. [1]

Em casos onde a resistividade do material é estável, cria-se um local de alta resistência elétrica, o que gera um caminho restrito a passagem de corrente entre as partes do sistema, nesse caso, este processo é que chamamos de concentração de corrente.

As mudanças que ocorrem na corrente de solda apresentam maior influência no desenvolvimento do calor, sendo esta, a variável mais crítica, onde uma pequena alteração na corrente total poderá afetar significativamente a solda.

Se baixarmos a corrente de solda em $10 \%$, o calor será reduzido em cerca de $20 \%$ na região de soldagem. [15]

\subsubsection{Resistência dinâmica de contato.}

A resistência elétrica de contato bem como a corrente, sofrem mudanças durante o processo de soldagem a ponto na medida em que o material é aquecido e funde, estas mudanças podem ser definidas como estágios, onde a resistência elétrica varia muito de acordo com a condição da superfície de contato e das propriedades do material.

Imediatamente após o início do ciclo de soldagem, ocorre aumento da tensão entre os eletrodos e uma redução da corrente ao longo do restante do ciclo de soldagem, a voltagem diminui e se mantem constante enquanto que a corrente aumenta e se mantem constante. [16]

Estas mudanças na tensão e na corrente também pode ser representada como resistência instantânea ou dinâmica. Para que se possa caracterizar de forma detalhada o processo de soldagem por pontos, é necessário um acompanhamento contínuo das constantes mudanças que ocorrem durante o processo. [16] 
O estudo da resistência dinâmica pode contribuir com melhorias nos parâmetros de soldagem a ponto e também pode auxiliar no desenvolvimento das condições de controle de qualidade da solda além de auxiliar no entendimento dos mecanismos envolvidos no processo.

A Figura 8 representa de forma esquemática, os parâmetros elétricos dinâmicos na soldagem de um tipo de aço carbono e ilustra as variações de resistência, corrente e tensão.

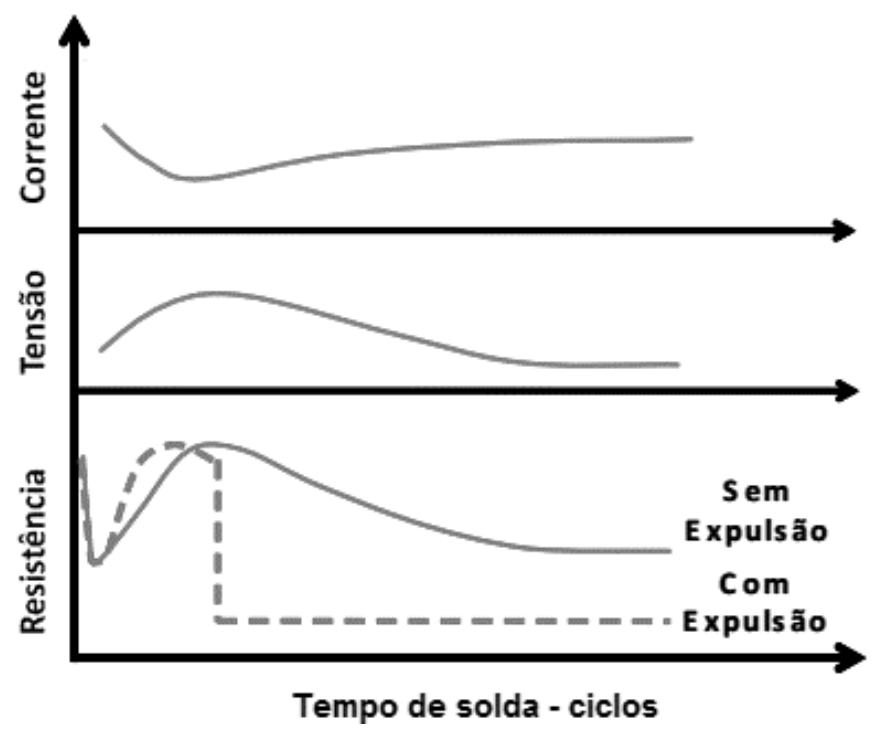

Figura 8. Representação esquemática dos parâmetros elétricos dinâmicos durante a solda de um aço carbono. [16]

Os fenômenos que ocorrem durante a formação do ponto de solda, podem ser entendidos através da análise das curvas de resistência dinâmica.

Além de auxiliar no entendimento dos fenômenos que ocorrem durante a formação do ponto, os efeitos das alterações na corrente elétrica e a força do eletrodo, também podem estar relacionados com as curvas de resistência dinâmica.

De acordo com Dickinson et. al [16], dois parâmetros podem ser utilizados para controlar o processo de solda a ponto por resistência elétrica, a resistência dinâmica e a energia de expulsão crítica.

A Figura 9 mostra um esquema das curvas de resistência dinâmica e os estágios envolvidos durante o processo de formação do ponto de solda. 


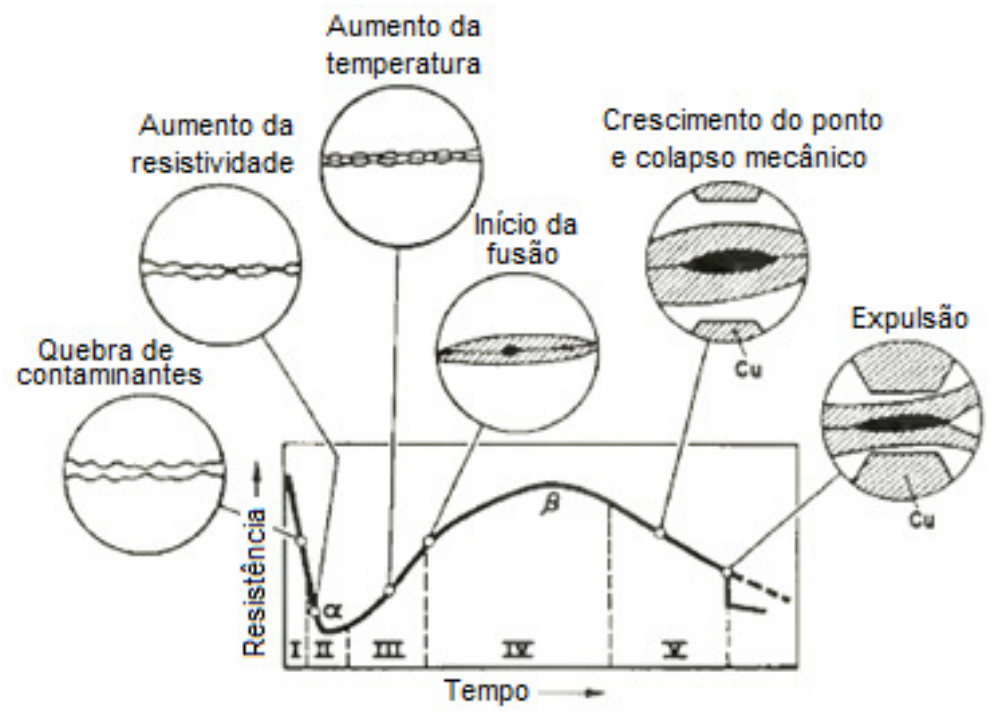

Figura 9. Curva de resistência dinâmica teórica. [16]

Através de uma análise mais abrangente da Figura 9, Dickinson et. al, [16] relacionaram os principais fenômenos que ocorrem em cada estágio da formação do ponto, sendo:

\section{Estágio I: Quebra da superfície.}

Em condições normais, camadas de óxidos e contaminantes estão presentes na superfície das chapas, como estes elementos são isoladores, a resistência de contato inicial será alta, assim, haverá uma concentração de calor para fragmentar estes óxidos e contaminantes reduzindo a rugosidade na superfície, desta forma, haverá uma redução na resistência.

\section{Estágio II: Contato metal-metal:}

Neste estágio ocorre um aquecimento concentrado na região de contato entre as chapas, esse aquecimento é contínuo e reduz as imperfeições superficiais, o que faz com que aumente a área de contato e ocorra uma redução da resistência elétrica, ao mesmo tempo, o aumento da temperatura resulta no aumento da resistividade, gerando assim um efeito oposto.

A competição entre esses dois mecanismos de resistência, determina a posição do ponto $\alpha$. Eventualmente, o aumento da área de contato vai ser superada pelo efeito do aumento da temperatura e a resistência total irá começar a subir. 


\section{Estágio III: Elevação da temperatura:}

Ocorre um aumento da resistividade devido ao aumento da temperatura, começa a ocorrer a fusão e a transição para o estágio seguinte tende a ocorrer próximo ao ponto de inflexão da curva.

\section{Estágio IV: Fusão:}

A fusão que ocorre neste estágio, sofre a influência direta de três mecanismos: a) o aumento contínuo da temperatura da peça, gerando aumento da resistividade e da resistência;

b) o calor gerado provoca a fusão na interface, aumentando a região fundida e diminuindo a resistência elétrica devido ao aumento da área transversal do fluxo de corrente;

c) com o amolecimento da região, ocorre um colapso mecânico, o pico da região $\beta$ indica a estabilização da temperatura com o início do crescimento do ponto e a redução da resistência mecânica.

Estágio V: Crescimento do ponto e colapso mecânico:

Ocorre o crescimento do ponto e o colapso mecânico que diminuem a resistência, neste estágio ocorre a expulsão e a queda acentuada da curva.

\subsection{Sequência do processo de soldagem a ponto}

O processo de soldagem a ponto apresenta uma sequência de operação a qual pode ser definida através de tempos específicos para cada operação, desde o fechamento de contato entre as partes até o recuo das mesmas.

Os tempos de cada sequência de operação devem ser controlados de maneira precisa para garantir o máximo de eficiência e qualidade durante o processo.

As etapas de tempos sequenciais necessários para a geração de um ponto de solda são cinco: o tempo de pré-pressão, o tempo de subida, o tempo de solda, o tempo de descida e o tempo de pós-pressão.

A Figura 10 ilustra de forma simples a sequência do processo de soldagem a ponto por resistência elétrica. 


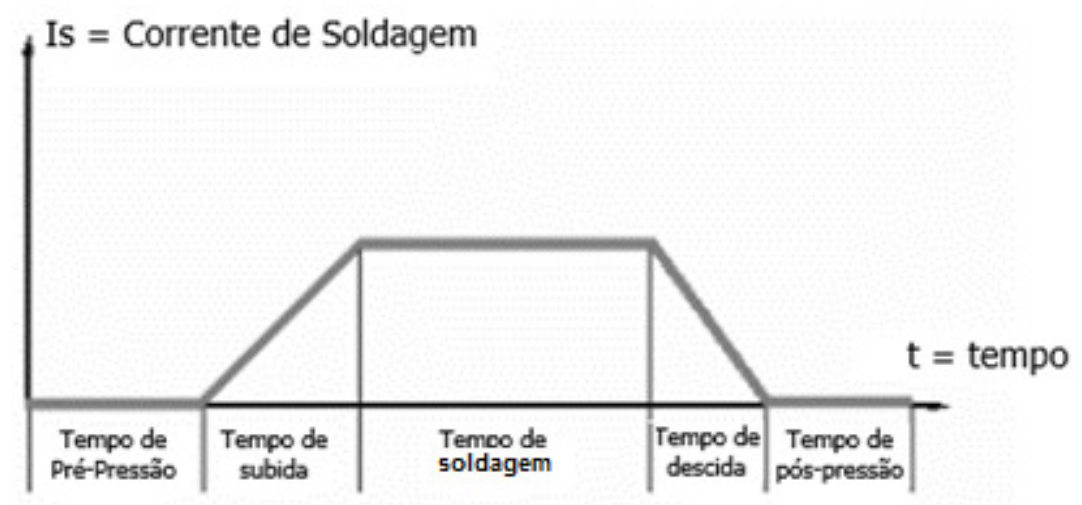

Figura 10. A sequência do processo de soldagem a ponto. [4]

\subsection{Parâmetros de soldagem a ponto}

Os parâmetros de soldagem são as condições pré-determinadas de valores e combinações adequadas entre si em que um ponto de solda é gerado para unir as partes, a determinação de valores adequados, definem o resultado final e a qualidade da solda gerada.

É importante que os parâmetros sejam criteriosamente analisados, testados e validados antes da implantação a fim de que custos desnecessários e perdas sejam geradas.

A qualidade do ponto de solda depende dentre outros fatores, da regulagem adequada dos equipamentos e o constante monitoramento de parâmetros como a corrente elétrica, o período de tempo e a pressão exercida no conjunto.

Todos esses parâmetros são aplicados em um ciclo de soldagem. A resistência elétrica da peça não é um parâmetro do processo, porém não pode ser desprezada por ser parte fundamental na geração de calor do sistema devido ao efeito Joule.

A determinação dos parâmetros de soldagem e as especificações de engenharia são fatores determinantes para uma boa solda. Os parâmetros podem ser definidos e registrados em procedimentos e ou tabelas que ilustram os valores a serem considerados para a operação.

Para determinação do diâmetro adequado do ponto, é necessário conhecer a espessura dos materiais que serão soldados, de maneira geral, o diâmetro do ponto de solda está relacionado diretamente as espessuras das chapas, onde as chapas mais finas e leves requerem soldas menores do que chapas mais grossas e pesadas. 
A estimativa de diâmetro do ponto mais adequado a cada condição, pode ser determinada através da Equação 4:

$$
\mathrm{d}=5 .(e)^{1 / 2}=\mathrm{d}=\sqrt{e} \quad(\mathrm{~mm})
$$

Onde:

d = diâmetro;

$\mathrm{e}=$ espessura da chapa em $\mathrm{mm}$

Neste caso, ocorre uma tendência de que o diâmetro do ponto de solda seja cerca de $10 \%$ maior do que o diâmetro da ponta do eletrodo. Outro fator importante a ser considerado, é o afastamento entre os pontos de solda, devido principalmente a existência de fuga de corrente pelos pontos pré-existentes. [13]

Da mesma forma com que o diâmetro está relacionado as espessuras das chapas, o afastamento entre os pontos, também leva em consideração este fator para definir qual a melhor disposição dos pontos nas chapas.

Para situações onde as espessuras de chapas são idênticas, considerando-se a relação $\left(e_{1}=e_{2}=e\right)$ o afastamento entre os centros dos pontos é dado através da Equação 5:

$$
\mathrm{L}=14 . \mathrm{e}+3 \quad(\mathrm{~mm})
$$

Onde:

e = espessura das chapas;

Para situações onde as espessuras das chapas são diferentes, considerando (e, $\left.e_{1}>e_{2}\right)$ esse afastamento é dado através da Equação 6:

$$
L=\left(14 \cdot e_{2}+3\right) \cdot\left(e_{1}+e_{2}\right)^{1 / 3} \quad(m m)
$$

Onde: 
e = espessura das chapas;

A distância da borda das peças também deve ser considerada para que não ocorra interferência em situações de montagem de componentes, ou até mesmo, que possa a interferir na qualidade da solda. [13]

Nesta condição, a relação de espessura das chapas não é considerada para efeito de afastamento da borda, ou seja, considera-se a da mesma forma, chapas de igual ou diferentes espessuras. A distância da borda das peças, é determinada através da Equação 7:

$$
B=S / 2 \quad(m m)
$$

Onde:

$\mathrm{S}=$ espessura;

Alguns valores de parâmetros também podem ser definidos e utilizados como referência durante a otimização dos parâmetros de soldagem, podem ser utilizadas tabelas que contém informações e ou relação de valores de espessura da chapa, força do eletrodo, tempo de soldagem, corrente de soldagem e diâmetro mínimo do ponto de solda. Informações importantes e dados de referência podem ser consultados através de normas especificas como AWS e ou até mesmo de acordo com os requisitos específicos de cada segmento ou aplicação. [15]

\subsubsection{Tempo de pré-pressão}

É o tempo de fechamento da pinça de solda, onde se inicia o ciclo e os eletrodos passam a pressionar as chapas que serão soldadas, esse tempo deve garantir a união das peças e estabilizar a força dos eletrodos.

O tempo deve ser também adequado para compensar possíveis variações de contato entre os eletrodos e as chapas e permitir a estabilização da força prédeterminada para a operação. [28] 
O tempo de pré-pressão pode ser reduzido com a otimização dos tempos de soldagem, essa redução pode ser alcançada aumentando-se a velocidade do fechamento da pinça de soldagem.

\subsubsection{Tempo de subida}

É o tempo determinado entre o a liberação de corrente elétrica no sistema até que ela atinja o seu valor pré-determinado para a realização da solda.

Neste intervalo ocorre um aumento de pressão e o aquecimento do material de solda, esse aumento de pressão pode resultar numa redução da resistência nas interfaces, é necessário então um aumento de corrente elétrica ou de tempo para compensar a queda na resistência. [6]

\subsubsection{Tempo de soldagem}

O tempo de soldagem é o intervalo onde ocorre a formação do ponto de solda, neste momento, a corrente de soldagem gera calor suficiente para aquecer a região de contato entre os eletrodos e as chapas e o material se funde dando origem ao ponto de solda.

O tempo de soldagem deve ser observado atentamente para que não seja longo o suficiente para gerar endentação e aderência do eletrodo na chapa, ou até mesmo gerar furos nas peças. Se o tempo de soldagem for muito curto, é possível que não haja a formação do ponto de solda completo, ou apresente apenas um pequeno ponto de solda não totalmente fundido. [6]

\subsubsection{Tempo de descida}

O tempo de descida é o intervalo onde a corrente de soldagem sofre uma gradativa redução de intensidade, nesse momento, o consumo de energia e a corrente diminui fazendo com que ocorra um resfriamento lento da região soldada e a 
solidificação do ponto, permitindo a aderência das chapas e o afastamento das pinças de solda. [6]

\subsubsection{Tempo de pós-pressão}

O tempo de pós-pressão marca a transição entre o término do ponto de solda e o intervalo de início do próximo ponto, os eletrodos continuam em contato com as chapas, porém a corrente de solda já foi interrompida. A partir desse estágio, é possível também que os eletrodos sejam recuados e a peça seja soldada seja liberada.

\subsection{Efeitos e Influências na soldagem}

A qualidade do ponto de solda depende dentre outros fatores, da regulagem adequada dos equipamentos e o constante monitoramento dos parâmetros, como a corrente elétrica, o período de tempo e a pressão exercida no conjunto.

As baixas correntes influenciam diretamente na formação das zonas de fusão, gerando zonas menores, por consequência, geram soldas de resistência mecânica inferior, ao passo que com o aumento da corrente ocorre um aumento no diâmetro do ponto e um aumento significativo na resistência mecânica.

Um período de tempo controlado para cada tipo de material ou peça contribui para a qualidade final do ponto de solda e evitar falhas em potencial após o ponto

gerado. É necessário observar também a relação entre o tempo de soldagem e a produtividade do processo ao qual está inserido.

A pressão exercida no conjunto eletrodo chapa influencia diretamente a resistência, quanto maior a pressão exercida pelo eletrodo na chapa de aço, maior é a tendência de aumento da área de contato entre as partes, reduzindo desta forma a sua resistência. [7] 


\subsubsection{Efeitos dos tempos iniciais do processo}

A variação dos tempos iniciais do processo de soldagem, aliada a estabilização da força aplicada nos eletrodos para gerar o ponto de solda, provocam alterações na resistência de contato e alteram a energia térmica do ponto de solda.

Ao iniciar a corrente de solda sem estabilização da força de compressão, ocorre um acréscimo no valor da resistência de contato, gerando aumento da massa do material fundido, esses efeitos não permitem que os valores dos parâmetros se mantenham estáveis. [7]

\subsubsection{Efeitos da força de soldagem}

As superfícies das chapas galvanizadas apresentam irregularidades microscópicas com a presença de pequenos picos, onde no momento em que essas chapas são submetidas a baixas forças de contato durante a soldagem, o contato irá ocorrer apenas nas extremidades dos picos, representando uma área muito pequena, o que gera uma resistência alta de contato.

O aumento da força de soldagem do eletrodo gera uma deformação nesses pequenos picos superficiais, aumentando a área de contato na interface entre as chapas e reduzindo a resistência de contato. [19]

\subsubsection{Efeitos dos tempos de soldagem}

A variação no tempo de soldagem tem efeitos diferentes durante a geração do ponto de solda, pois a distribuição da temperatura nas chapas e nos eletrodos varia de acordo com tempo de soldagem aplicados. Portanto, a qualidade do ponto gerado está ligada diretamente ao período de tempo em que o calor é transferido para o sistema.

Os tempos relativamente curtos de soldagem, acabam gerando uma energia de soldagem elevada no sistema, se o tempo aplicado for menor que o tempo mínimo necessário para a dissipação de calor na região, ocorre a expulsão de material. 
Os tempos de soldagem mais longos que o tempo mínimo de dissipação de calor, gera uma energia relativamente baixa no sistema, essa baixa energia reduz 0 tamanho do ponto de solda mas aumenta a zona afetada pelo calor (ZAC). [7]

Os efeitos do tempo de soldagem devem ser observados com atenção durante a parametrização do processo e durante a operação, pois suas consequências para o processo acabam interferindo de forma direta na qualidade do ponto de solda gerado, onde deve ser levado em conta também, o tempo de resfriamento de acordo com a espessura de cada chapa para que desta forma, problemas sejam evitados e haja uma melhor resistência mecânica das chapas.

\subsubsection{Efeitos do tempo de resfriamento}

O processo de soldagem apresenta perda de calor por condução para o metalbase e também para os eletrodos. A dissipação do calor se dá através de taxas variáveis durante a aplicação da corrente, bem como após a corrente ser aplicada até que a solda tenha se resfriado completamente.

A soldagem de materiais de alta condutibilidade exige a aplicação de alta corrente de soldagem para garantir uma boa qualidade da solda, a necessidade de alta corrente auxilia também na compensação da perda de calor, embora a soldagem a ponto nestes tipos de materiais é bastante complexa.

Mesmo após a corrente de soldagem ter sido interrompida, os eletrodos permanecem em contato com o material, isso faz com que a região do ponto de solda seja resfriada rapidamente.

A taxa de dissipação do calor no metal-base circundante decresce com tempos de soldagem longos, devido a um maior volume de metal base ter sido aquecido nesta região. [17]

\subsubsection{Efeitos das condições superficiais e revestimento}

As propriedades mais uniformes da solda são obtidas quando as condições superficiais do material a ser soldado são favoráveis. 
A limpeza da superfície a ser soldada é ponto importante não só para garantir a uniformidade da solda, mas também para que não ocorra a migração de diferentes contaminantes para a ponta do eletrodo no momento do contato entre as partes, esses contaminantes acabam influenciando na deterioração dos eletrodos, reduzindo a vida útil do mesmo. [9]

É importante neste caso, que a resistência de contato da superfície das chapas que estão em contato com os eletrodos seja a menor possível, para garantir a qualidade final do ponto, por isso a necessidade de condições superficiais favoráveis na soldagem a ponto.

As chapas de aço revestidas com zinco são importantes na indústria automotiva em razão da alta resistência a corrosão, fator determinante no contexto da fabricação de um automóvel, porém a soldagem desse tipo de material mostra-se mais complexa do que um aço não revestido, devido principalmente a necessidade de tempos e níveis de corrente maiores para garantir diâmetros de pontos satisfatórios.

A principal dificuldade encontrada na soldagem de um aço galvanizado é a grande diferença entre os pontos de fusão do zinco do revestimento e do aço, onde a ebulição do zinco ocorre em temperatura mais baixa do que a fusão do aço, por esta razão irá ocorrer a evaporação do zinco durante a formação do ponto de solda.

O contato entre o cobre do eletrodo e o zinco presente na superfície da chapa revestida, promove uma reação entre os materiais e a formação de ligas na face do eletrodo, resultando também no consumo excessivo do eletrodo e redução na sua vida útil. [9]

Algumas técnicas de soldagem ou até mesmo métodos avançados vem sendo utilizados com sucesso no processo de soldagem de chapas com revestimento em zinco. Um dos métodos que podem ser utilizados para minimizar os efeitos do zinco na soldagem a ponto por resistência elétrica de chapas galvanizadas é o "burn-zinc" que é uma técnica tradicionalmente utilizada para a queima da camada de zinco do revestimento.

Esse método utiliza a adição de um impulso no início do ciclo de soldagem, onde aplica-se uma corrente mais alta do que normalmente se aplicaria em um processo normal de soldagem a ponto por um período curto de tempo.

O procedimento provoca a queima antecipada, ou evaporação, do zinco presente na região a ser soldada devido a pressão aplicada nesta região, o zinco 
então é expulso para a região próxima ao ponto e permitirá o contato entre as chapas sem revestimento, formando um ponto de solda mais adequado. [21]

\subsubsection{Influência dos eletrodos}

No processo de solda a ponto, a área de contato do eletrodo é responsável pelo controle dimensional do ponto de solda determinando o seu diâmetro, além dessa característica, a área de contato também controla a densidade da corrente que passa pelo sistema no momento da formação do ponto.

O cobre do eletrodo é um tipo de material condutor de eletricidade, sua fabricação envolve a presença de elementos de liga e deve garantir preferencialmente boa resistência mecânica e dureza para suportar as variações térmicas as quais está exposto durante o processo.

A influência dos eletrodos no processo de soldagem a ponto passa pela sua capacidade de geração de calor, além da condução da corrente de soldagem e a capacidade de refrigeração da região soldada, portanto, os eletrodos são parte importante e interferem diretamente no processo. [8]

\subsection{Problemas operacionais durante o processo}

Embora estando atento as condições de soldagem e variáveis envolvidas, é possível que durante o processo, problemas potenciais possam surgir, entre os principais problemas em potencial durante o processo de soldagem a ponto, podemos citar o desvio de corrente, a indentação, a distribuição de corrente, o desalinhamento dos eletrodos e a expulsão de material.

\subsubsection{Desvios de corrente}

O ponto de solda realizado subsequente ao anterior apresentará uma corrente menor quanto menor for a distância entre esses pontos, isto ocorre devido ao desvio 
da corrente pelo ponto anterior, onde as chapas estão ligadas eletricamente através do ponto de solda, essa ligação acaba formando uma resistência paralela. [28]

Outro ponto subsequente ao segundo, irá acrescer mais uma resistência paralela, neste caso a corrente passa a ser desviada por dois caminhos.

O aumento da distância do primeiro ponto em relação ao terceiro ponto, resulta em um desvio de corrente menor do primeiro ponto em relação ao segundo ponto. $\mathrm{O}$ contato entre a pinça de solda e a peça também é responsável por desvios de corrente, neste caso, é importante manter o isolamento entre as partes. [28]

\subsubsection{Indentação excessiva}

A indentação é uma profundidade gerada na região superficial da chapa soldada através da pressão dos eletrodos durante o processo de soldagem. Apesar de ser difícil de ser eliminada, salvo em caso uso de eletrodos, procedimentos e controles especiais, a indentação é aceitável na maioria dos casos, onde depende muito de cada especificação de norma aplicada e ou padrão pré-estabelecido. Algumas normas descrevem o critério de aceitação de até $30 \%$ da espessura das chapas soldadas, este critério de aceitação também deve observar a questão estética da região soldada e o nível de exposição a cargas dinâmicas da carroceria. [29]

A indentação pode causar em algumas situações uma ligação frágil entre as chapas em razão da redução da espessura na região soldada, também poderá causar a separação entre as chapas soldadas em casos mais extremos de indentação profunda. [29]

\subsubsection{Distribuição da corrente}

A circulação da corrente de soldagem deve ser o mais uniforme possível durante o processo de soldagem, esta condição deve ser respeitada analisando-se as espessuras de chapas a serem soldadas e o perfil de cada eletrodo.

Para a soldagem de chapas de mesma espessura, é importante que os eletrodos produzam a mesma área de contato nas chapas, em casos onde há 
diferença de espessuras entre as chapas, os eletrodos devem ter áreas de contato que atendam a necessidade de distribuição uniforme do calor durante o processo, neste caso, o eletrodo com a maior área deve estar em contato com a chapa de maior espessura. [28]

\subsubsection{Alinhamento e desalinhamento de eletrodos}

O alinhamento dos eletrodos é um fator importante durante o processo de soldagem e deve ser considerado mesmo em casos de troca de eletrodos ou tempo de uso dos mesmos.

$\mathrm{O}$ desalinhamento dos eletrodos, pode alterar a área do ponto formado $\mathrm{e}$ reduzir a resistência mecânica do ponto, pois a alteração da área de contato acaba gerando uma distorção na geometria do ponto. $O$ desalinhamento dos eletrodos pode gerar também um aumento da indentação, a expulsão do material e o desgaste prematuro dos eletrodos reduzindo a sua vida útil. [28]

\subsubsection{Expulsão de material}

O processo de soldagem por resistência elétrica não tem adição de material, logo, a expulsão de material refere-se a perda de material líquido fundido da região da solda, o excesso de calor gerado é o principal fator da expulsão de material.

A expulsão de material está ligada diretamente ao alinhamento dos eletrodos, pois quando os eletrodos estão alinhados, ocorre uma pressão uniforme dos eletrodos em relação ao núcleo do ponto no estado liquido durante a soldagem.

Essa pressão uniforme ao redor do ponto e uma maior força dos eletrodos em relação a força no núcleo do ponto de solda, acaba não resultando em expulsão de material. Em casos onde os eletrodos estão desalinhados, há um desequilíbrio na pressão ao redor do ponto e poderá haver sim expulsão de material onde a pressão estiver menor. [28] 


\subsection{Ensaios e métodos de controle de qualidade da solda}

As empresas normalmente desenvolvem seus próprios métodos e procedimentos de controle de qualidade da solda, onde são realizadas inspeções visuais ou ensaios específicos de controle, os dados normalmente são registrados e quantificados para melhor avaliar os critérios mais adequados.

Os procedimentos desenvolvidos pelas empresas, normalmente seguem padrões descritos em normas específicas internacionais que descrevem a sistemática do processo e os pontos a serem observados.

As avaliações são normalmente realizadas através de ensaios destrutivos, ensaios não destrutivos, ou até mesmo por inspeção visual, neste caso, deverá haver um grau de conhecimento e habilidade prévia do inspetor para que o padrão seja garantido. [24]

Os ensaios destrutivos são muito úteis para verificação da qualidade da solda onde a sua comprovação é obtida através de um conjunto de amostras aleatórias que passam por diferentes tipos de ensaios e controles.

Os meios de controle de qualidade da solda a ponto são determinados de acordo com as necessidades de cada empresa, onde desenvolvem seus próprios critérios de aceitação, documentos de controle, frequência e também o controle dos resultados e as ações que estes resultados podem desencadear.

Os testes práticos avaliam a resistência da junta soldada e a qualidade do ponto gerado, o controle das características físicas como o diâmetro do ponto de solda, a profundidade de indentação, as propriedades de resistência do material e a região da ZAC são pontos importantes observados nos testes práticos de controle de qualidade da solda.

\subsubsection{Ensaio por destacamento}

Um dos ensaios mais comuns utilizados em linha de montagem para verificação da soldagem é o ensaio de destacamento utilizando martelo e talhadeira, pois mostrase um teste que apresenta facilidade de operação, baixo custo de realização, fácil aprendizado e execução na fábrica. 
O teste é realizado com o rompimento ou a fratura ao redor do ponto de solda formado em corpos de prova de chapas ou materiais idênticos aos utilizados, em alguns casos o ensaio é realizado na própria peça logo após o processo de solda, posteriormente ocorre a medição do diâmetro do ponto remanescente, o qual permanece na chapa que sofreu a fratura, essa medição de diâmetro é realizada com o auxílio de um paquímetro e considera a média dos pontos de solda de todos os ensaios. [18]

A avaliação do teste é muito subjetiva neste caso por não levar em consideração alguns fatores envolvidos no teste como a força de cisalhamento e as deformações causadas pelo processo de rompimento ou destacamento das chapas.

Também é possível avaliar a qualidade da solda de forma semelhante, preparando-se corpos de prova padrão com duas partes iguais da chapa de aço utilizada, realizar a solda e em seguida fixa-los em um dispositivo adequado, as amostras de chapas soldadas são então dobradas ou forçadas ao distanciamento entre si até que ocorra o rompimento do ponto, com o uso de um paquímetro, medese o diâmetro do ponto de solda em direções perpendiculares entre si, o diâmetro dos pontos de solda que permanecem aderidos a chapa medida, é que irá determinar a qualidade da solda comparando-se com medidas de diâmetros de pontos de referência de acordo com a especificação necessária para cada aplicação, normalmente cada empresa possui seu próprio modelo e os diâmetros de referência para comparação com os testes. [18]

Em casos onde os pontos de solda apresentam assimetria ou se deformam por conta do ensaio de destacamento, são necessárias diversas medições em posições diferentes para que se possa estabelecer o diâmetro encontrado no teste, esse procedimento se faz necessário devido à variação de pontos irregulares onde não é possível estabelecer o diâmetro médio aproximado e a medição torna-se por isso, prejudicada quanto a precisão dos resultados.

A Figura 11 ilustra o formato do corpo de prova utilizado para avaliar a qualidade do ponto de solda. 


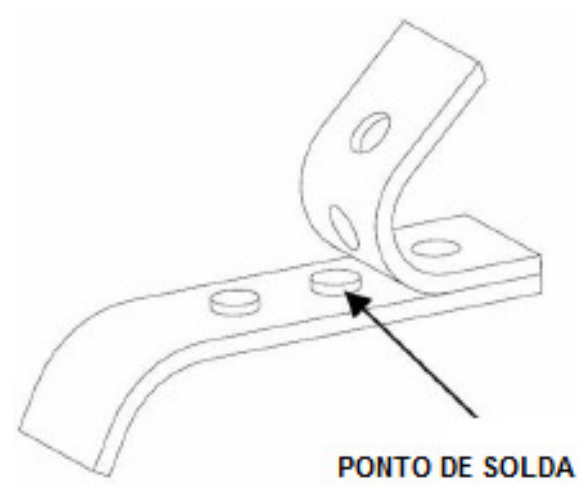

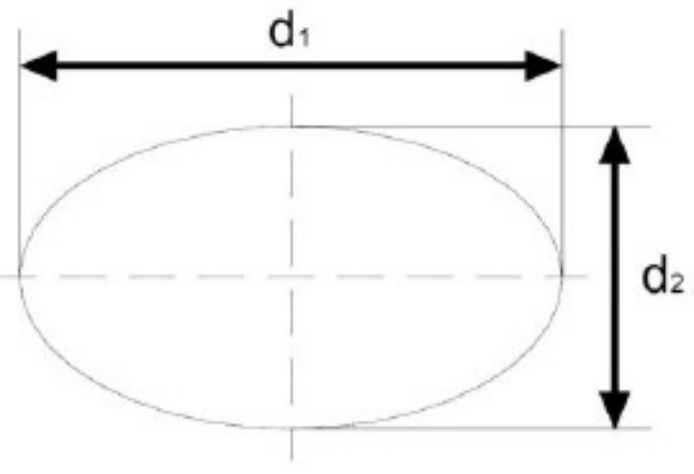

DIMENSÕES DO PONTO DE SOLDA

Figura 11. llustração do ensaio de destacamento e medição do ponto de solda. [18]

\subsubsection{Ensaio de tração}

Outro ensaio comum realizado para acompanhar a qualidade da soldagem é o ensaio de tração, também realizado através de corpos de prova de chapas soldadas, onde aplica-se uma carga tracionando as partes de forma uniaxial crescente até que haja o rompimento do corpo de prova, neste caso, deve-se medir a variação do comprimento L em função da carga aplicada P. [18]

O ensaio de tração requer a utilização de equipamento específico de tração e também é bastante usual, pois além de fornecer dados mais seguros que os testes manuais, é possível obter também dados das características dos materiais ensaiados como o limite de resistência a tração e também o limite de escoamento do material ensaiado. [18]

O resultado do valor absoluto da carga de ruptura encontrado na amostra será considerado para análise comparativa de acordo com normas especificas e parâmetros de cada fabricante, este ensaio apresenta boa confiabilidade de resultados.

\subsubsection{Ensaios metalográficos}

Um método de ensaio bastante preciso e utilizado na indústria também, é o ensaio metalográfico, este ensaio está subdividido em macrografia e micrografia, e 
requer uma preparação inicial da amostra para que seja submetida a análise.

O ensaio metalográfico pode ser verificado a olho nu ou com o auxílio de um microscópio para ampliação da imagem do corpo de prova, a ampliação da imagem varia de acordo com a necessidade da análise, qualidade do corpo de prova entre outros fatores, normalmente é utilizado uma ampliação de até 1000 vezes.

A avaliação da qualidade da solda é verificada através de uma seção transversal do ponto de solda previamente preparado através do lixamento e polimento da amostra em níveis elevados, onde pode-se verificar a presença de alguma descontinuidade na região que foi soldada e ainda analisar de forma detalhada qual o nível de homogeneidade e heterogeneidade do material, também pode ser observado o diâmetro do ponto de solda e a penetração alcançada no ponto de solda realizado. [18]

O processo de lixamento deve ser realizado com tipos de lixa de diferentes granulações sempre iniciando da maior granulação para a menor granulação, seguido de uma solução de pasta de diamante e acompanhado de ataque químico por aplicação na superfície ou mesmo por imersão de uma solução composta por ácido nítrico em concentrações que variam de $2 \%$ a $5 \%$ do volume.

\subsubsection{Ensaio por ultrassom}

O ensaio por ultrassom é também um método de controle de qualidade, porém mais avançado que requer equipamentos sofisticados, neste ensaio, são aplicados basicamente dois métodos diferentes:

- Método de transparência, que utiliza vibrações constantes ultrassônicas no ensaio, é mais aplicado a chapas de metal, barras e perfis metálicos por seção transversal, peças pequenas determinação do tamanho e localização do defeito;

- Método de reflexão, que utiliza pulsos ultrassônicos, é o método mais usado na indústria automotiva para qualificação da soldagem a ponto, é mais aplicado em barras e perfis metálicos por eixo longitudinal, peças forjadas ou fundidas de tamanho grande ou em peças pequenas na localização da área e da profundidade do defeito.

A aplicação de determinado método, depende basicamente do formato de cada peça a ser analisada e do tipo de defeito a ser detectado. 
Para ambos os métodos a serem adotados, quanto maior a frequência de vibração, menor será o tamanho do defeito possível de ser detectado. [13]

A Figura 12 ilustra os diferentes métodos de ensaio realizados por ultrassom e auxiliam no entendimento das diferentes condições de funcionamento.

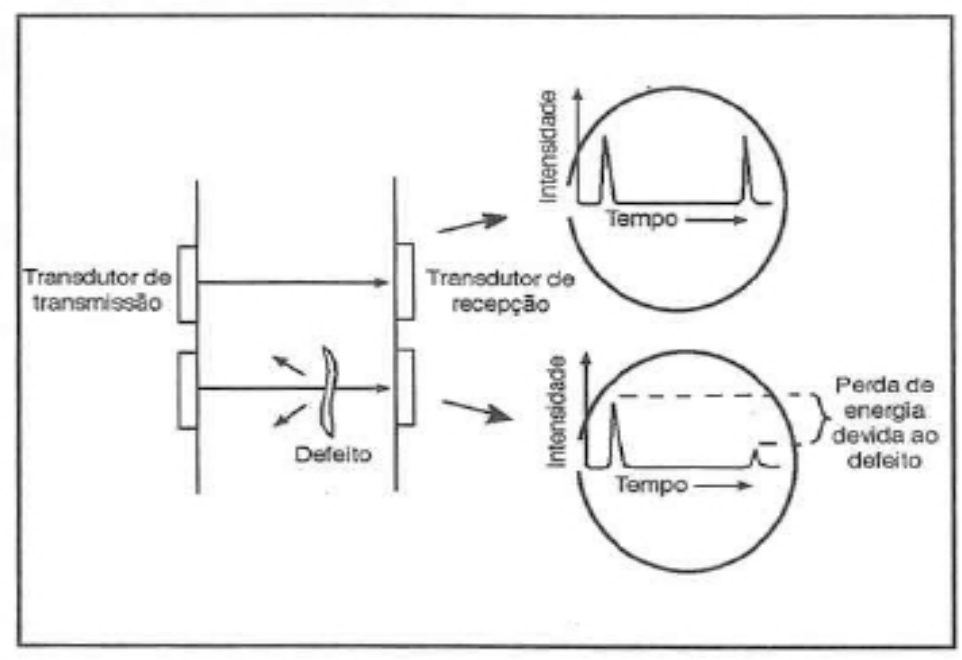

(a)

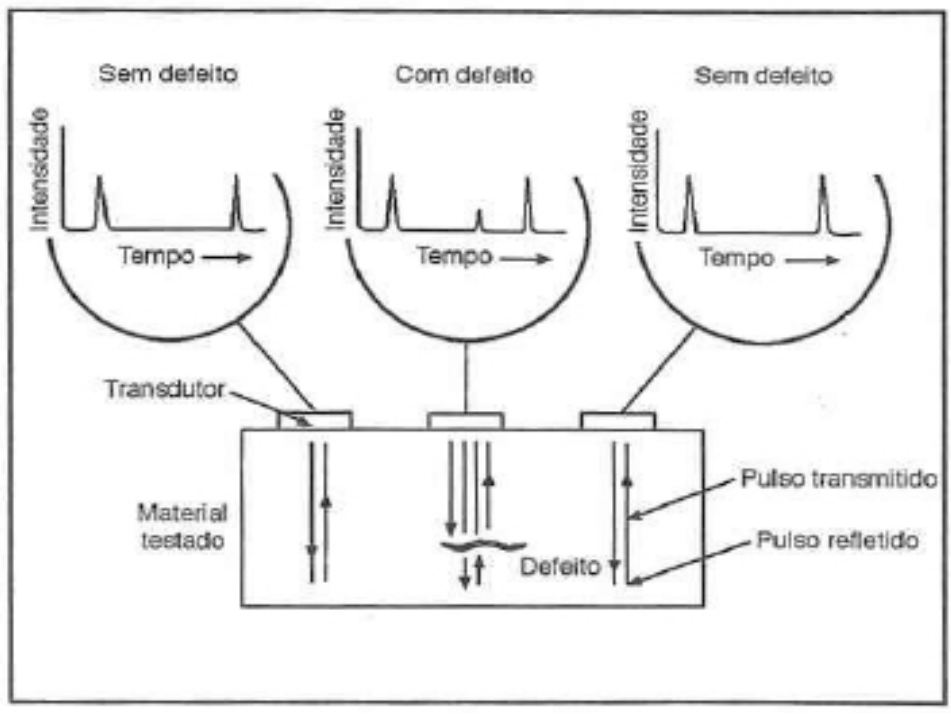

(b)

Figura 12 - Métodos de ensaio por ultrassom (a) Penetração; (b) Reflexão. [13] 
Tabela 1. Itens básicos para inspeção visual na soldagem a ponto. [13]

\begin{tabular}{|c|c|c|}
\hline ITENS A INSPECIONAR & POSSÍVEIS PROBLEMAS & POSSÍVEIS CAUSAS \\
\hline $\begin{array}{l}\text { Coloração da superfície da área } \\
\text { fundida: } \\
\text { * Superfície sem alteração de cor } \\
\text { com ponto claro ou sem marca de } \\
\text { aquecimento da superfície de } \\
\text { contato com os eletrodos. }\end{array}$ & $\begin{array}{l}\text { *Baixa temperatura gerando } \\
\text { redução da área de fusão. }\end{array}$ & $\begin{array}{l}\text { * Aumento da força entre } \\
\text { eletrodos; } \\
\text { * Diminuição da corrente ou tempo } \\
\text { de solda; } \\
\text { * Desgaste ou fim da vida útil dos } \\
\text { eletrodos; } \\
\text { * Erro na curva do stepper; } \\
\text { * Produto fora da especificação } \\
\text { dimensional ou físico química; } \\
\text { * Fuga de corrente na máquina; } \\
\text { * Controlador programado para } \\
\text { sem solda; } \\
\text { * Eletrodo fora de especificação. }\end{array}$ \\
\hline $\begin{array}{l}\text { Coloração da superfície da área } \\
\text { fundida e luz emitida: } \\
\text { * Superfície escura além da área } \\
\text { de fusão dos materiais. Área em } \\
\text { torno do ponto fica marcada pela } \\
\text { alteração da temperatura do } \\
\text { material; } \\
\text { * Grande quantidade de luz } \\
\text { gerada na área de contato dos } \\
\text { eletrodos com o produto ou na } \\
\text { superfície de fusão. }\end{array}$ & $\begin{array}{l}\text { * Alta temperatura de fusão, } \\
\text { aumentando a zona afetada pelo } \\
\text { calor, ZAC, ocasionando grande } \\
\text { indentação e dependendo do } \\
\text { material, fragiliza a ZAC, gera } \\
\text { trincas, contamina a superfície } \\
\text { com o material do eletrodo e } \\
\text { outras implicações metalúrgicas. }\end{array}$ & $\begin{array}{l}\text { * Elevação no tempo ou na } \\
\text { corrente de soldagem; } \\
\text { * Falha na refrigeração dos } \\
\text { eletrodos; } \\
\text { * Produto fora da especificação } \\
\text { dimensional ou físico química. }\end{array}$ \\
\hline Expulsão de material & $\begin{array}{l}\text { * Alta temperatura de fusão, } \\
\text { com retirada de material, } \\
\text { respingo, ocasionando vazios na } \\
\text { zona de fusão, rebarbas na } \\
\text { superfície da área de contato, } \\
\text { aumento da indentação, } \\
\text { contamina a superfície com o } \\
\text { material do eletrodo e outras } \\
\text { implicações metalúrgicas. }\end{array}$ & $\begin{array}{l} \\
\text { * Elevação na corrente de solda; } \\
\text { * Diminuição da força de contato } \\
\text { entre os eletrodos; } \\
\text { * Falha na refrigeração dos } \\
\text { eletrodos; } \\
\text { * Produto fora da especificação } \\
\text { dimensional ou físico química; } \\
\text { * Folgas no sistema de } \\
\text { acionamento dos eletrodos; } \\
\text { * Assentamento ruim das chapas; } \\
\text { * Material contaminado com } \\
\text { impurezas; } \\
\text { * Eletrodo fora de especificação. }\end{array}$ \\
\hline $\begin{array}{l}\text { Geometria da área fundida. } \\
\text { * Área de fusão ovalada; } \\
\text { * Amassamento irregular do } \\
\text { produto. } \\
\text { As partes do produto fundem } \\
\text { diferentemente. }\end{array}$ & $\begin{array}{l}\text { * Alteração da área de contato } \\
\text { ocasionando diminuição da área } \\
\text { de fusão; } \\
\text { * Projeção de material; } \\
\text { * Aumento da indentação. }\end{array}$ & $\begin{array}{l}\text { * Alteração da força entre } \\
\text { eletrodos; } \\
\text { * Desgaste ou fim de vida útil dos } \\
\text { eletrodos; } \\
\text { * Produto fora da especificação } \\
\text { dimensional ou físico química; } \\
\text { * Eletrodo fora de especificação; } \\
\text { * Folgas no sistema de } \\
\text { acionamento dos eletrodos; } \\
\text { * Desalinhamento dos eletrodos. }\end{array}$ \\
\hline
\end{tabular}




\subsection{Os aços galvanizados automotivos}

A aplicação do aço galvanizado na indústria automotiva é crescente com o passar dos anos, pois há uma preocupação permanente em relação a durabilidade dos automóveis e a boa resistência a corrosão que as chapas galvanizadas apresentam, é parte importante dentro desse processo crescente de substituição dos aços carbono comum por aços galvanizados.

Embora atualmente existe uma variedade de revestimentos galvanizados, os principais processos de revestimento empregados em chapas de aço na indústria automotiva são por eletrodeposição ou eletrolítico também chamado de eletrogalvanização e o processo por imersão a quente. [9]

Os processos de revestimento de chapas de aço estão sendo aperfeiçoados continuamente, o que a torna cada vez mais resistente a ambientes agressivos de corrosão. Embora não seja comum o uso para a aplicação automotiva e estejam mais direcionadas a uso na linha branca e na construção civil, as chapas de aço prépintado, são um exemplo recente deste avanço.

A Tabela 2 apresenta os principais processos de revestimento e as principais características envolvidas na produção de chapas de aço galvanizado automotivo.

Tabela 2: Principais tipos e características de aços galvanizados automotivos. [9]

\begin{tabular}{|l|c|c|c|c|}
\hline $\begin{array}{c}\text { PROCESSOS DE } \\
\text { REVESTIMENTO }\end{array}$ & $\begin{array}{c}\text { TIPOS DE } \\
\text { REVESTIMENTO }\end{array}$ & $\begin{array}{c}\text { NOME COMUM } \\
\text { UTILIZADO }\end{array}$ & $\begin{array}{c}\text { PESO DO } \\
\text { REVESTIMENTO } \\
\mathbf{g} / \mathbf{m}^{\mathbf{2}}\end{array}$ & $\begin{array}{c}\text { ESPESSURA DO } \\
\text { REVESTIMENTO } \\
\boldsymbol{\mu} \mathbf{m}\end{array}$ \\
\hline \multirow{2}{*}{ Imersão a quente } & Zinco & Galvanizado & $60-120$ & $8-17$ \\
\cline { 2 - 5 } & Zinco-ferro & Galvannealed & $40-70$ & $6-10$ \\
\hline \multirow{2}{*}{ Eletrodeposição } & Zinco & Eletrogalvanizado & $60-90$ & $8-13$ \\
\cline { 2 - 5 } & Zinco-níquel & Eletrogalvanizado & $20-50$ & $3-7$ \\
\hline
\end{tabular}

\subsubsection{Aços galvanizados por eletrodeposição}

A eletrodeposição ou eletro-galvanização, é um processo eletrolítico no qual o zinco é transferido de um ânodo para uma chapa de aço carregada negativamente e é aplicada uma camada de zinco em apenas um dos lados da chapa de aço, a 
espessura do revestimento de zinco neste caso, pode ser controlada através de modelos matemáticos. [30]

Este processo de galvanização é considerado de baixa temperatura e normalmente produz um revestimento superficial de zinco muito fino na superfície da chapa de aço, embora já citado, a espessura da camada depositada pode ser controlada. A corrente elétrica é um dos principais meios envolvidos no processo, sendo convertida inicialmente de corrente alternada para corrente continua através de retificadores onde são separadas as partes positivas e negativas da corrente elétrica. A parte negativa da corrente é colocada em contato com as chapas que receberão o revestimento, enquanto que a parte positiva é colocada em contato com o metal que irá os íons para a solução eletrolítica. [30]

Este processo também apresenta um acabamento mais liso, brilhante e uniforme na superfície da chapa, pois possui uma camada de revestimento menor e custo mais baixo se comparado com o processo por imersão a quente. [30]

\subsubsection{Aços galvanizados por imersão a quente}

Considerado um processo relativamente simples, a galvanização por imersão a quente é o processo onde as peças ou chapas de aço são imersas em zinco líquido a temperatura de $450^{\circ} \mathrm{C}$, durante a imersão, as peças reagem imediatamente e através do contato com o zinco líquido nas superfícies, formam uma camada de liga de Fe e Zn. [30]

Após a imersão inicial, a reação entre o Fe e o Zn diminui de intensidade e a espessura do revestimento não aumenta e não varia de forma muito significativa, mesmo a peça permanecendo por mais tempo imersa no banho de zinco, usualmente, o tempo de imersão das chapas no liquido é de 1 ou 2 minutos. [30]

A velocidade de passagem do aço no banho de zinco líquido é que determina a espessura da camada de revestimento, geralmente a espessura de camada situase acima de $6 \mu \mathrm{m}$ por face e a quantidade de zinco depositada normalmente fica acima de $40 \mathrm{~g} / \mathrm{m}^{2}$. [30] 
A galvanização por imersão a quente possui um custo mais elevado se comparado a galvanização por eletrodeposição, em contrapartida, apresenta maior aderência, resistência a abrasão e também maior uniformidade no revestimento. [30]

\subsubsection{Soldabilidade de aços revestidos e não revestidos}

Os aços revestidos exigem maior quantidade de corrente para soldagem do que os aços sem revestimento. A fusão do $\mathrm{Zn}$ presente na superfície da chapa de aço revestido, gera um deslocamento de material de solda para as regiões circundantes ao ponto de solda, esse material deslocado acaba desviando uma parte da corrente envolvida na formação do ponto de solda, dessa forma, há uma necessidade maior de corrente para soldar esse tipo de aço. [31]

O processo de fusão do revestimento na interface eletrodo-chapa acaba gerando uma reação entre o $\mathrm{Zn}$ fundido com o $\mathrm{Cu}$ da face do eletrodo, essa reação forma uma fina camada de latão na ponta do eletrodo, porém, uma parte do Zn acaba oxidando e permanece depositada nas extremidades de contato dos eletrodos. [31]

A fusão do zinco superficial e a formação de latão na extremidade dos eletrodos, contribuem significativamente para que as características superficiais e elétricas dos eletrodos, sejam alteradas.

A medida que os pontos de solda são realizados a uma corrente constante, ocorre uma degradação da ponta do eletrodo, gerando desgaste e pequenas cavidades o que aumenta o diâmetro da extremidade do eletrodo e consequente diminuição da densidade da corrente de soldagem até que nenhum ponto de solda mais possa ser gerado. [31]

A soldagem de aços sem revestimento com $\mathrm{Zn}$, não apresentam problemas e limitações como verificados na soldagem de aços revestidos e tão pouco ocorrem reações químicas entre as superfícies dos eletrodos e das chapas, isso reduz o desgaste dos eletrodos, gerando uma vida útil maior do eletrodo. Um aço não revestido apresenta, portanto, menor complexidade na soldagem, menor desgaste de eletrodos e correntes mais baixas de soldagem. [31] 
As chapas revestidas por eletrodeposição ou eletrogalvanização, apresentam melhor soldabilidade, se comparadas as revestidas pelo processo de imersão a quente, pois a camada de revestimento é mais fina e uniforme na superfície.

\subsection{0 eletrodo de soldagem a ponto.}

A maioria dos eletrodos são produzidos pelo processo de estampagem a frio que garantem uma dureza elevada, acima de $70 \mathrm{HB}$, os eletrodos produzidos com a liga $\mathrm{Cr}$-Zr possuem uma boa condutividade elétrica dificultando o gradeamento nas chapas e demonstram bom desempenho quando expostos a altas temperaturas. [6]

Os eletrodos da liga Cu-Zr são fabricados através de conformação e usinagem a frio, gerando excelentes níveis de desempenho e propriedades mecânicas, além de alto nível de condutividade elétrica. [12]

O material mais utilizado para fabricação de eletrodos na indústria automobilística até pouco tempo era o $\mathrm{Cu}$-Cr-Zr, porém atualmente, é utilizado em grande escala, o eletrodo de $\mathrm{Cu}-\mathrm{Zr}$, pois estes apresentam correntes nominais de soldagem e de fuga menores que o anterior, porém apresentam condutividade elétrica superior ao eletrodo anterior. [15]

Alguns eletrodos podem ser fabricados com ligas de cobre livres de oxigênio, estas, representam uma diferença considerável em relação a outras ligas de cobre, pois apresentam resistência mecânica superior.

O custo estimado de cada eletrodo varia de acordo com a liga, formato, aplicação entre outros fatores, para o caso do eletrodo objeto desse estudo, o custo estimado é de cerca de U\$2,00 para aquisição pela indústria, este valor foi verificado com base nas condições comerciais praticadas pelo mercado.

Os tipos e as especificações dos eletrodos de cobre e suas ligas, estão classificados por classes de acordo com a RWMA Resistance Welder Manufacturers Association, órgão americano que classifica os eletrodos pela sua composição química e pelas suas propriedades mecânicas. [21]

O eletrodo é um dos componentes que requer atenção especial dentro do processo dada suas particularidades e aplicações, visto que, é a peça do conjunto que manterá o contato elétrico e mecânico entre as partes para gerar o ponto de solda. 
O eletrodo também define a área de contato durante a formação do ponto e contribui para o resfriamento do ponto de solda. Os eletrodos são submetidos a condições severas de trabalho, para suportar essas condições, é importante que suas propriedades mecânicas, térmicas e elétricas sejam suficientes para suporta-las. [28]

\subsubsection{Características dos materiais para eletrodo.}

As ligas a base de cobre pertencem ao chamado Grupo A da RWMA e estão subdivididas em classes diferentes de acordo com a sua composição química e propriedades mecânicas, como dureza por exemplo.

Os materiais dos eletrodos devem apresentar qualidades especificas que permitam trabalhar em condições desfavoráveis, tais qualidades basicamente são:

- Alta condutividade térmica

- Alta condutividade elétrica;

- Alta resistência ao amolecimento e temperaturas elevadas;

- Alta dureza e resistência ao desgaste em elevadas temperaturas;

A classificação dos eletrodos de soldagem por resistência é descrita a seguir:

Classe 1: Compostos por materiais não tratáveis termicamente, com resistência mecânica obtida por trabalho a frio, apresenta alta condutividade térmica e elétrica.

Classe 2: Compostos por materiais tratáveis termicamente, resistência mecânica obtida por tratamento térmico ou combinação entre este e trabalho a frio, possuem boas propriedades mecânicas, baixa condutividade elétrica e térmica se comparados ao modelo anterior, são os mais utilizados na indústria pois permitem o uso em diversos tipos de metais e condições.

Classe 20: Compostos por materiais tratáveis termicamente, possuem baixa condutividade elétrica e altas propriedades mecânicas quando comparado com os das outras classes, dureza aproximada de $90 \mathrm{HRB}$, apresenta alta resistência ao desgaste, indicado para situações de alta pressão e alta resistência elétrica.

Classe 20: Composta por materiais capazes de resistir a altas taxas de pressão e calor se comparados as classes 1 e 2 , estes tipos de eletrodos são produzidos através de cobre e material refratário. [21]

A tabela 3 mostra as principais características dos materiais dos eletrodos. 
Tabela 3. Características dos materiais dos eletrodos [21]

\begin{tabular}{|c|l|c|c|c|}
\hline $\begin{array}{c}\text { Classe } \\
\text { RWMA }\end{array}$ & \multicolumn{1}{|c|}{$\begin{array}{c}\text { Descrição } \\
\text { Composição }\end{array}$} & $\begin{array}{c}\text { Condutividade } \\
\text { I.A.C.S. }\end{array}$ & $\begin{array}{c}\text { Dureza } \\
\text { HB }\end{array}$ & $\begin{array}{c}\text { Mecanismo } \\
\text { Endurecimento }\end{array}$ \\
\hline $\begin{array}{c}\text { Classe 1 } \\
\text { RWMA 1 }\end{array}$ & $\begin{array}{l}\text { Cu-Zr - Cobre-Zircônio } \\
0,15 \% \mathrm{Zr}\end{array}$ & $90 \%$ & $70 \mathrm{HB}$ & Precipitação \\
\hline $\begin{array}{c}\text { Classe 2 } \\
\text { RWMA 2 }\end{array}$ & $\begin{array}{l}\mathrm{Cu}-\mathrm{Cr} \text { - Cobre-Cromo } \\
1 \% \mathrm{Cr}\end{array}$ & $85 \%$ & $83 \mathrm{HB}$ & Precipitação \\
\hline $\begin{array}{c}\text { Classe 2 } \\
\text { RWMA 2 }\end{array}$ & $\begin{array}{l}\mathrm{Cu}-\mathrm{Cr}-\mathrm{Zr}-\text { Cobre-Cromo-Zircônio } \\
1 \% \mathrm{Cr}-0,25 \% \mathrm{Zr}\end{array}$ & $85 \%$ & $83 \mathrm{HB}$ & Precipitação \\
\hline $\begin{array}{c}\text { Classe 20 } \\
\text { RWMA 20 - } \mathrm{Al60}\end{array}$ & $\begin{array}{l}\mathrm{Cobre} \mathrm{Resistente} \mathrm{por} \mathrm{Dispersão} \\
\mathrm{Cu}-\mathrm{Al}_{2} \mathrm{O}_{3}-1,1 \% \mathrm{Al}_{2} \mathrm{O}_{3}\end{array}$ & $85 \%$ & $75 \mathrm{HB}$ & Dispersão \\
\hline
\end{tabular}

\subsubsection{Formato dos eletrodos.}

A forma dos eletrodos é determinada basicamente de acordo com os materiais a serem soldados, onde o formato de cada eletrodo contribui para a definição da geometria e o diâmetro dos pontos e também possuem a função de conduzir a corrente elétrica, transmitir a força mecânica e manter alinhadas as peças de trabalho durante o processo.

O diâmetro das faces de contato dos eletrodos com as peças a serem soldadas devem ser aproximadamente 1,6 mm maior do que o ponto de solda, essa definição é considerada como referência de maneira geral para o uso de diferentes formatos de eletrodos durante o processo. [1]

Os eletrodos utilizados na soldagem a ponto possuem formas variadas que são na grande maioria padronizadas pelos principais fabricantes, o uso específico de cada modelo, varia de acordo com a posição ou região a ser soldada, o tipo de pinça a ser utilizada, espessura das chapas, corrente de soldagem, composição e revestimento da chapa de aço, entre outras variáveis. [28]

Em razão das características, tipos de materiais e produtos a serem fabricados, alguns modelos de eletrodos são utilizados em quantidade muito maior do que outros, pois algumas regiões apresentam certas restrições a determinados formatos.

Entre os formatos de eletrodos mais utilizados pela indústria atualmente, podemos destacar os modelos constantes na Figura 13. 
A

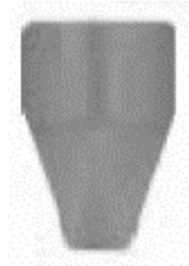

B

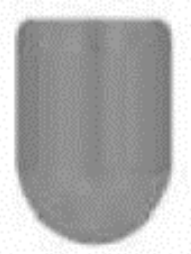

$\mathrm{C}$

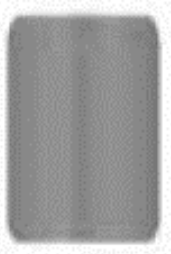

D

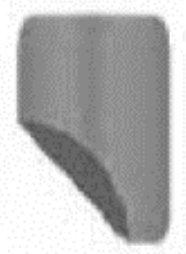

$\mathbf{E} 45^{\circ}$

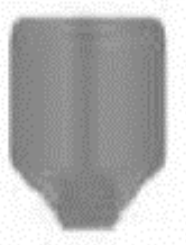

E $20^{\circ}$

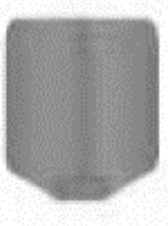

F

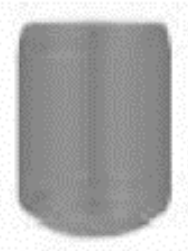

S ou G

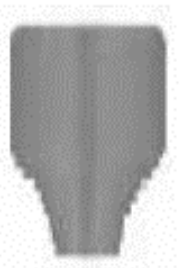

Figura 13. Formatos dos principais tipos de eletrodos. [28]

Tabela 4. Principais características dos eletrodos conforme formatos [21]

\begin{tabular}{|c|c|c|}
\hline FORMATO & UTILIZAÇÃO & OBSERVAÇÕES \\
\hline A & $\begin{array}{l}\text { Eletrodo de uso geral. Excelente quando } \\
\text { estão em perfeito alinhamento e usados } \\
\text { em pinças de acionamento com força axial } \\
\text { tipo C, mas não recomendado para } \\
\text { máquinas com força radial tipo } X \text {. }\end{array}$ & $\begin{array}{l}\text { O melhor formato para afiação e soldagem com } \\
\text { eletrodos grandes tipo B ou F. Rápido tempo de } \\
\text { troca e preparação. Não tolera erros de } \\
\text { posicionamento, deve ter posicionamento bem } \\
\text { preciso. Boa vida útil, pois demora para amassar. } \\
\text { Baixa indentação. Muito complicado para alinhar } \\
\text { em máquinas tipo X, por causa do acionamento } \\
\text { radial. }\end{array}$ \\
\hline B & $\begin{array}{l}\text { Uso geral quando chapas têm pouco ou } \\
\text { nenhum de revestimento. } \\
\text { Limitados na espessura do material, a } \\
\text { 2,5mm chapa mais espessa. } \\
\text { Indicado para máquinas manuais. }\end{array}$ & $\begin{array}{l}\text { Amassamento ligeiramente mais demorado que do } \\
\text { formato A. Tende a acumular zinco mais facilmente. } \\
\text { Facilmente afiado. Fácil posicionamento. Tolera } \\
\text { erros de posicionamento. Alta indentação inicial. }\end{array}$ \\
\hline C & $\begin{array}{l}\text { Uso específico. Usado como eletrodo de } \\
\text { back. Em chapas de diferentes espessuras, } \\
\text { uma espessa e outra fina, é usado na chapa } \\
\text { de maior espessura. Indicado em máquinas } \\
\text { automáticas ou robôs. }\end{array}$ & $\begin{array}{l}\text { Geralmente permanece frio. Longa vida útil } \\
\text { amassamento muito demorado. Não } \\
\text { permite afiação. }\end{array}$ \\
\hline $\mathrm{D}$ & $\begin{array}{l}\text { Uso específico. Indicado em soldagem de } \\
\text { bordas, pequenas áreas de acesso, ou perto } \\
\text { de superfícies curvas. }\end{array}$ & $\begin{array}{l}\text { O alinhamento deve ser muito preciso e } \\
\text { cuidadoso. Troca demorada. Não permite } \\
\text { afiação. Amassamento rápido. }\end{array}$ \\
\hline$E$ & $\begin{array}{l}\text { Eletrodo de uso geral. Excelente quando } \\
\text { estão em perfeito alinhamento e usados } \\
\text { em pinças de acionamento com força axial, } \\
\text { tipo C, não bom para máquinas com força } \\
\text { radial, tipo X. Recomendado para máquinas } \\
\text { automáticas, robô, alguns manuais, em } \\
\text { conjunto com back de cobre. }\end{array}$ & $\begin{array}{l}\text { Limitado para uso em alguns modelos e } \\
\text { acessos de máquinas manuais. } \\
\text { Rápido tempo de troca e preparação. Tolera } \\
\text { pequenos erros de posicionamento, deve ter } \\
\text { posicionamento preciso. Média vida útil } \\
\text { amassamento normal. Baixa indentação. } \\
\text { Muito complicado para alinhar em máquinas } \\
\text { tipo X, por causa do acionamento radial. }\end{array}$ \\
\hline $\mathrm{F}$ & $\begin{array}{l}\text { Uso específico. Bom para uso em chapas de } \\
\text { grande espessura, maior que } 2,5 \mathrm{~mm} \text {. } \\
\text { Indicado para máquinas manuais, ou } \\
\text { automáticas. Usado em conjunto com } \\
\text { outros formatos com bom assentamento. }\end{array}$ & $\begin{array}{l}\text { Afiação deve ser precisa. Pode gerar erros } \\
\text { de distribuição de calor, descentralização do } \\
\text { ponto. Amassamento demorado, boa vida } \\
\text { útil. Baixa indentação. }\end{array}$ \\
\hline G & Uso geral. & Não permite afiação \\
\hline $\mathrm{S}$ & $\begin{array}{l}\text { Uso geral. Ajuda a reduzir aderência dos } \\
\text { eletrodos em chapas galvanizadas. }\end{array}$ & Não permite afiação \\
\hline
\end{tabular}




\subsubsection{Desgaste dos eletrodos}

Em razão dos eletrodos estarem submetidos a altas pressões e temperaturas durante a soldagem, o que gera uma alteração na estrutura original do material, o eletrodo acaba perdendo dureza à medida que os pontos são gerados.

A variação na dureza do eletrodo está ligada diretamente ao aumento da temperatura e ao desgaste, dessa forma, quanto maior a dureza, menor o desgaste e vice-versa, a durabilidade dos eletrodos passa pela capacidade de cada liga de suportar e manter a dureza em altas temperaturas.

Em função do desgaste na ponta do eletrodo, ocorre um aumento na área de contato, por outro lado, na recuperação da ponta, pode haver diminuição nesta área de contato. Ambas as situações causam perdas no processo.

No primeiro caso, haverá diminuição da densidade superficial de corrente, diminuindo o rendimento do processo.

No segundo, haverá aumento da densidade superficial da corrente, acarretando sobre aquecimento do eletrodo e diminuição da sua vida útil. [19]

Alguns procedimentos podem evitar que o desgaste dos eletrodos, continuem afetando a qualidade da solda, entre eles podemos citar a substituição dos eletrodos, a fresagem e o uso de curvas de compensação de corrente, onde há um controle no acréscimo da corrente de soldagem.

A vida útil do eletrodo também está relacionada com o sistema de refrigeração do eletrodo, pois a refrigeração atua de forma a minimizar os impactos no desgaste provocado pela ação de altas temperaturas, deve-se posicionar o "tubo defletor" de maneira correta, garantindo um fluxo de água adequado dentro do eletrodo.

\subsubsection{Desempenho em serviço}

A corrente de soldagem apresenta-se como como um dos mais importantes parâmetros dentro do processo, a resistência do ponto de solda é derivada deste parâmetro e também onde podem ocorrer a maioria das variações que por consequência, poderão gerar falhas. 
As curvas de corrente ou a programação das curvas de compensação de corrente são adotadas para controlar o tempo de duração da subida da corrente de soldagem, este controle está ligado diretamente ao número de pontos gerados.

Os eletrodos novos acabam concentrando mais o calor na região de solda por conta de sua menor área de contato, ao longo da sua vida útil e devido ao seu desgaste, essa concentração de calor acaba diminuindo ou se distribuindo em uma área maior, embora a quantidade de calor para gerar o ponto seja a mesma de quando o eletrodo foi instalado.

O efeito da diminuição da concentração de energia no ponto de solda pode ser reduzido ou neutralizado empregando-se o recurso da curva de compensação de corrente de solda em função do desgaste dos eletrodos de solda. A curva de compensação de corrente, mantem de forma constante a concentração de calor na região do ponto de solda e permite a compensação de uma variável denominada como densidade de corrente.

A determinação do limite de reajuste de uma curva de concentração é dada principalmente pela capacidade do transformador fornecer corrente e pelas condições do eletrodo de modo geral.

Alguns fatores influenciam diretamente nas curvas de programação de corrente ou programação de stepper, um deles é a quantidade de pontos que a máquina irá executar antes do aumento da corrente e outro representa o valor da subida de corrente para cada incremento.

Ambos os fatores sofrem influência da existência ou não do processo de dressagem dos eletrodos, é possível observar que nos casos onde a dressagem ocorre, a taxa de aumento de corrente é mais baixa, beneficiando o eletrodo, pois se a taxa for muito alta, os níveis de corrente serão também muito altos e irá ocorrer uma aceleração no desgaste dos eletrodos.

\subsubsection{Fresagem dos eletrodos}

A fresagem da capa de eletrodo, também denominada como dressagem, visa garantir não só a qualidade do ponto de solda, mas principalmente economia no 
processo de soldagem. Consiste em usinar de forma rápida e simples a extremidade do eletrodo garantindo desta forma, a geometria original do eletrodo.

O assunto vem ganhando importância ano a ano na indústria automotiva, visto que além de unir qualidade e economia no processo, acaba prolongando a vida útil do eletrodo, menos tempo de parada de linha entre outros ganhos indiretos.

A manutenção da geometria original do eletrodo mantém o nível de qualidade do ponto mesmo o eletrodo estando exposto a altas temperaturas e variações de dureza ao longo do processo.

Trata-se de um processo simples, de fácil e rápida operação, mas que exige atenção devido a importância de se manter o alinhamento e a concentricidade entre os eletrodos, do contrário, corre-se o risco de haver perdas das capas.

Entre os principais benefícios e ganhos envolvidos no processo de dressagem dos eletrodos, podemos citar os seguintes [15]

- Aumento de produtividade;

- Redução no consumo do eletrodo;

- Redução no tempo de substituição dos eletrodos;

- Redução no desperdício de eletrodos;

- Redução na parada dos equipamento e linha;

- Redução no consumo de energia;

- Redução no tamanho dos transformadores;

- Aumento no número de pontos soldados;

- Manutenção e estabilidade dos parâmetros de soldagem.

Existem apenas duas formas de fresagem, a lateral, usada principalmente em aços sem revestimento, que remove apenas o material que se forma na lateral do eletrodo e a fresagem de topo e lateral, usada principalmente em chapas zincadas, esta forma devolve o diâmetro original do ponto de solda, removendo o latão formado na extremidade da capa.

Basicamente, a fresagem de eletrodo pode ser classificada em três tipos:

Fresagem manual, que pode ser realizada em intervalos programados ou de acordo com as condições de desgaste que o eletrodo se encontra, neste caso, há necessidade de parar a linha; 
Fresagem pneumática, que pode ser instalada próximo a robôs ou áreas especificas para soldagem, com bom desempenho, eficiência e que dispensa a paralização da linha;

Fresagem off-line, que conta com um dispositivo especifico para esta tarefa, mas que gera perdas de produtividade na linha de produção.

\subsubsection{Intervalos de fresagem}

Os intervalos entre cada fresagem do eletrodo varia muito de acordo com as condições de soldagem e alguns fatores importantes como o tipo do eletrodo, o material utilizado, a espessura da chapa e o seu grau de limpeza, tipo de revestimento entre outros fatores.

Estas muitas variações praticamente impedem um cálculo aproximado para os intervalos de fresagem do eletrodo, porém, teoricamente é possível observar alguns valores recomendados para fresagem considerando o tipo de material soldado. [15]

Tabela 5. Frequência teórica recomendada para fresagem conforme material [15]

\begin{tabular}{|l|c|c|c|}
\hline \multicolumn{1}{|c|}{ Dados } & \multicolumn{3}{c|}{ Descrição } \\
\cline { 2 - 4 } & Não zincado & Zincado nas duas faces & Alumínio \\
\hline $\begin{array}{l}\text { Número de pontos de } \\
\text { solda realizados no } \\
\text { intervalo entre fresagens. }\end{array}$ & & & \\
Verificar: & 200 a 800 & 50 a 400 & 15 a 75 \\
-Espessura da chapa; & Pontos & Pontos & Pontos \\
-Dimensão do eletrodo; & & & \\
-Grau de limpeza da chapa; & & & \\
\hline
\end{tabular}

\subsubsection{Substituição dos eletrodos}

A substituição dos eletrodos pode ser utilizada como alternativa ao desgaste dos mesmos, porém é uma prática pouco usual, principalmente porque acaba influenciando diretamente no custo da soldagem e também na produtividade da linha. 
A substituição do eletrodo acaba provocando uma parada na linha de produção e com isso, gera um impacto maior no resultado, há casos também em que o eletrodo nem sequer foi utilizado por completo pelo sistema. [3]

O processo de substituição de eletrodos requer alguns cuidados importantes a fim de evitar problemas na sequência da operação, basicamente recomenda-se a avaliação da presença de folgas nas pinças e nos braços do equipamento, caso isso seja verificado, recomenda-se a troca da pinça por outra que esteja em melhores condições, isso evita que haja um desencontro das áreas de contato dos eletrodos. É recomendada também, a realização de uma inspeção geral de segurança do equipamento pelo operador antes do início das suas atividades.

O controle dos eletrodos é realizado basicamente através de um gabarito de controle dimensional, onde o operador pode verificar a condição aproximada para a troca do eletrodo, esse procedimento, independe do número de pontos soldados por cada operador.

A necessidade de substituição do eletrodo é definida após a verificação do tamanho de cada tipo de eletrodo no gabarito de controle, o qual permanece disponível para uso na linha de montagem do modelo.

A irregularidade ou deformação da geometria original do eletrodo proveniente da posição da pinça com o perfil da peça a ser soldada, o que acaba ocasionando o desgaste prematuro do eletrodo, interferindo na qualidade da solda, a má formação do ponto de solda, rompimento, e o aparecimento de rebarbas provenientes da falta de contato do eletrodo com a peça, esse fenômeno reduz significativamente a vida útil do eletrodo e dificulta a dressagem mecânica.

Em casos específicos é recomendado o uso da lima para a correção da geometria do eletrodo para garantir a qualidade do produto e ainda evitar a interrupção do processo produtivo, também deve ser considerado os casos em que a pinça não oferece recuo, o que impede a entrada da dressadora.

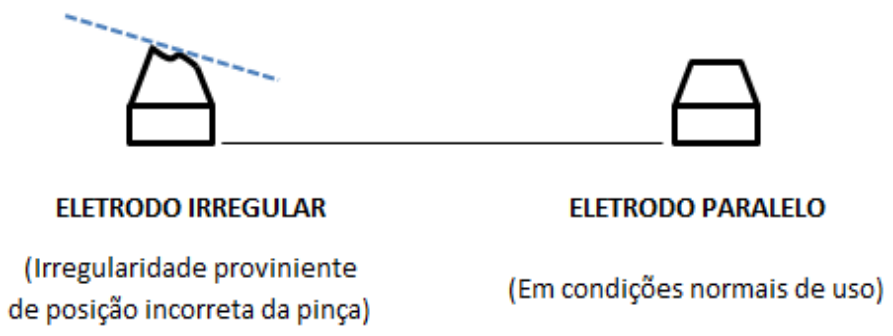

Figura 14. Modelo comparativo de eletrodos, irregular e normal. [Autor] 
A substituição dos eletrodos se dá de forma programada utilizando os recursos existentes no comando de solda. Cada pinça é programada individualmente levandose em consideração a quantidade de chapas, espessuras, posição da pinça e principalmente de acordo com a quantidade de pontos efetuados no processo.

A Figura 15 mostra um exemplo de avaliação de consumo de 3 tipos de eletrodos no processo, considerando as medidas nominais, eletrodos novos e após o uso, então, avalia-se a medida nominal inicial e final e verifica-se o peso em gramas de eletrodo consumido.

AVALIAÇÃO DO CONSUMO DOS ELETRODOS NO PROCESSO

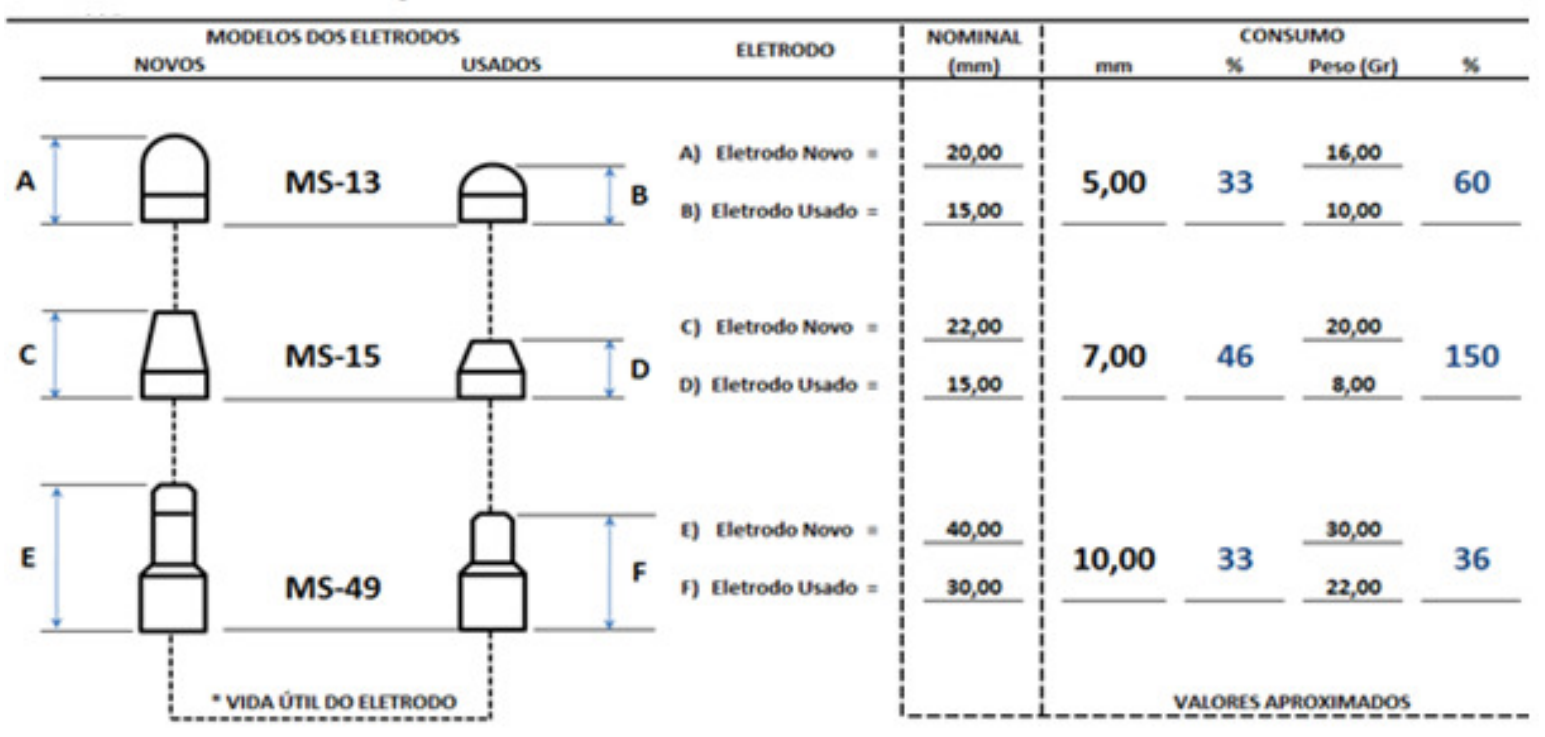

Figura 15 - Exemplo de avaliação do consumo de 3 tipos de eletrodos (Autor)

O gabarito ilustrado na Figura 16, mostra um recurso prático e de fácil utilização para avaliar o momento de substituição dos eletrodos, esse referencial orienta o operador para o limite mínimo ao qual o eletrodo deverá ter para ser então substituído.

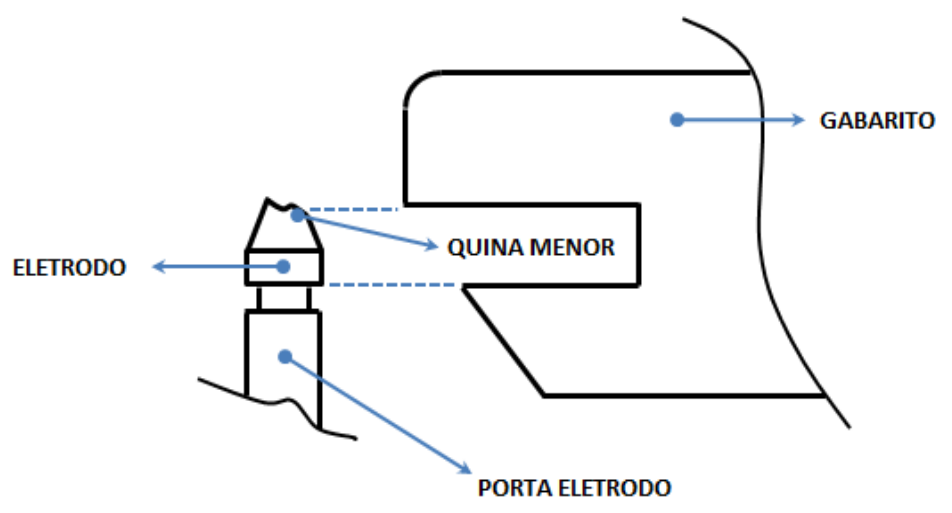

Figura 16. Modelo de gabarito para verificação da vida útil do eletrodo. (Autor) 


\subsubsection{Refrigeração dos eletrodos}

A refrigeração dos eletrodos é feita através de água que circula no sistema e é conduzida através de um tubo a uma distância próxima da extremidade do eletrodo, retornando através da secção externa do tubo e interna do eletrodo.

A refrigeração é aspecto de maior importância para garantir a manutenção do eletrodo, por esse motivo, deve ser monitorada e ajustada constantemente para garantir maior durabilidade aos eletrodos. [28]

O tubo de entrada d'água deve estar ajustado com mínima variação de distância em relação a ponta do eletrodo, pois neste caso, pode interferir na qualidade final do ponto de solda, gerando uma refrigeração ineficiente. $O$ afastamento do tubo condutor de água da ponta do eletrodo deve ser suficiente para permitir a circulação de água no sistema, nem tão curto ao ponto de gerar bolsas de vapor na e nem tão longo ao ponto de bloquear o fluxo de água do sistema. [28]

A qualidade e as especificações da água de refrigeração devem ser seguidas de acordo com as recomendações dos fabricantes do equipamento, pois a água utilizada deve atender especificações de transferência térmica e também evitar a incrustação de componentes sólidos dentro das tubulações.

O fluxo de água de refrigeração deve ser verificado inicialmente para garantir o bom funcionamento do sistema, sendo importante a checagem de todos os registros para verificar que estejam funcionando perfeitamente.

A inspeção das mangueiras é recomendada para verificar a presença de dobras, vazamentos ou interrupção da circulação de água, assim como o controle da temperatura da água de alimentação de recirculação também deve ser considerada.

\subsection{Diagrama de soldabilidade:}

Os diagramas de soldabilidade baseiam-se em função do tempo de soldagem e da corrente envolvida e são muito úteis na orientação das combinações necessárias de corrente e de tempo para que a solda seja realizada de forma adequada e apresente um resultado satisfatório. 
Uma corrente mínima dentro de um determinado tempo de soldagem, representa a especificação mínima necessária para que o ponto de solda seja formado, normalmente envolve o tamanho do ponto de solda gerado.

A corrente máxima de soldagem representa a expulsão de material de solda, e pode ser referenciada no diagrama para seleção de parâmetros adequados de soldagem. A determinação do limite máximo de corrente, é dificultado por diversas variáveis envolvidas, entre elas as condições superficiais do material a ser soldado, o desalinhamento dos eletrodos no momento da soldagem entre outras. [29]

A ocorrência de um desvio mínimo no valor da corrente de soldagem determinado, não interfere de maneira significativa na qualidade do ponto gerado, pois além de ser uma ocorrência comum durante o processo, permite também uma maior flexibilidade nos parâmetros de soldagem empregados. [29]

A Figura 17 representa esquematicamente um diagrama de soldabilidade e as relações entre o tempo de soldagem e a corrente de soldagem.

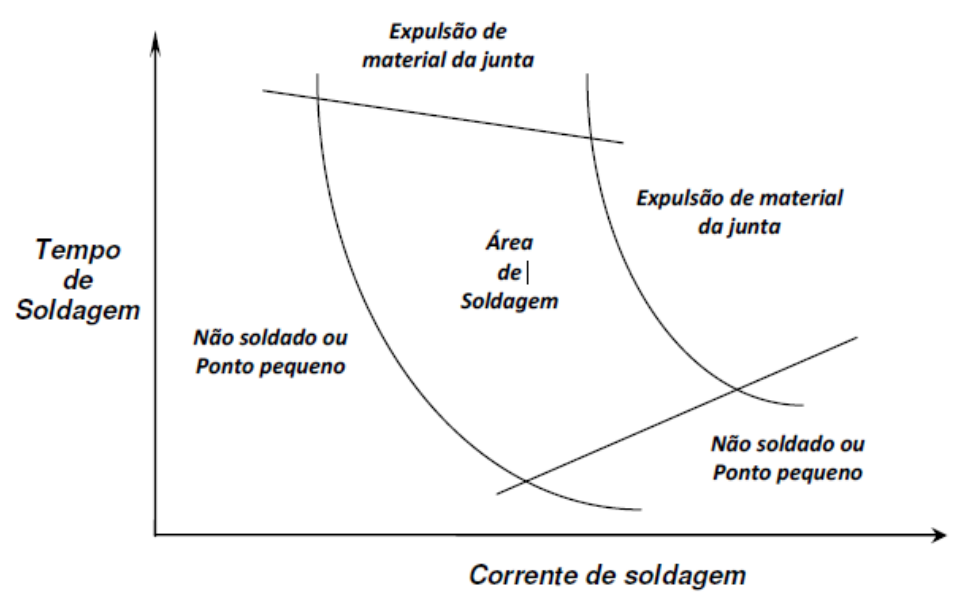

Figura 17 - Diagrama de soldabilidade. [13]

\subsection{Metalurgia física do cobre.}

O cobre está entre os metais mais utilizados nos dias de hoje, superado apenas pelo uso do aço e do alumínio, porém apresenta custo superior, quando comparados os valores de mercado entre esses materiais. 
Em aplicações especificas, o cobre puro e suas ligas, possuem características físicas e químicas muito particulares, o que o torna insubstituível em determinadas condições e solicitações.

Comercialmente, o cobre mostra-se como um material interessante na sua relação custo $\mathrm{x}$ benefício, pois dispõe de uma excelente resistência a corrosão, vida útil relativamente longa e valor residual atrativo. [24]

Abaixo estão detalhadas boa parte das suas características e propriedades:

Densidade: $8,96 \mathrm{~g} / \mathrm{cm}^{3}$ à $20^{\circ} \mathrm{C}$;

Ponto de fusão: $1083^{\circ} \mathrm{C}$;

Ponto de ebulição: $2.595^{\circ} \mathrm{C}$;

Coeficiente de dilatação térmica linear: $16,5 \times 10^{-6} \mathrm{~cm} / \mathrm{cm} /{ }^{\circ} \mathrm{C}$ à $20^{\circ} \mathrm{C}$;

Resistividade elétrica: $1,673 \times 10^{-6} \mathrm{ohm} . \mathrm{cm}$ à $20^{\circ} \mathrm{C}$;

Pressão de vapor: $101 \mathrm{~mm} \mathrm{Hg}$ à $20^{\circ} \mathrm{C}$;

Condutividade elétrica: $101 \%$ IACS à $20{ }^{\circ} \mathrm{C}$;

Calor latente de fusão: $50,6 \mathrm{cal} / \mathrm{g}$;

Calor específico: $0,0912 \mathrm{cal} / \mathrm{g} /{ }^{\circ} \mathrm{C}$ à $20^{\circ} \mathrm{C}$;

Estrutura cristalina: Cúbica de Faces Centradas

Não magnético.

\subsection{Recuperação do cobre.}

A recuperação marca o estágio inicial do processo de recozimento do cobre, pois a microestrutura que se mostra com grãos alongados e deformados, aparentemente, não sofre nenhuma alteração.

A recuperação é formada por um conjunto de mudanças que resultam na diminuição de defeitos micro estruturais sem que ocorra a migração de contornos de alto ângulo e onde uma grande parte das tensões são eliminadas trazendo estabilidade a estrutura do material.

Durante a recuperação, praticamente não ocorrem alterações significativas nas propriedades do material, a resistência a tração se mantem constante porem ocorre um aumento no alongamento e uma redução no limite de escoamento do material. 
Uma parte da energia de deformação interna que se encontra armazenada é liberada devido ao movimento das discordâncias e as tensões internas são aliviadas, como resultado de um aumento da difusão atômica em temperaturas elevadas.

\subsection{Recristalização do cobre.}

A recristalização representa a formação de um novo conjunto de grãos com dimensões iguais em todas as direções e livres de deformação, neste caso, a recristalização devolve ao material a sua condição original.

A ocorrência de recristalização está associada a geração de um número grande de defeitos durante a recristalização dinâmica, caracteriza-se por um fenômeno lento no início e que aumenta a velocidade da reação em sequência para depois retornar a uma velocidade mais lenta de reação.

Esses defeitos não podem ser eliminados apenas por recuperação, seja devido as altas taxas de deformação ou devido à baixa energia de defeito de empilhamento do material, aumentando o potencial termodinâmico para a recristalização. [3]

A textura de recristalização depende da orientação preferencial dos núcleos dos grãos recristalizados, a textura resultante é fortemente dependente da textura produzida pela deformação.

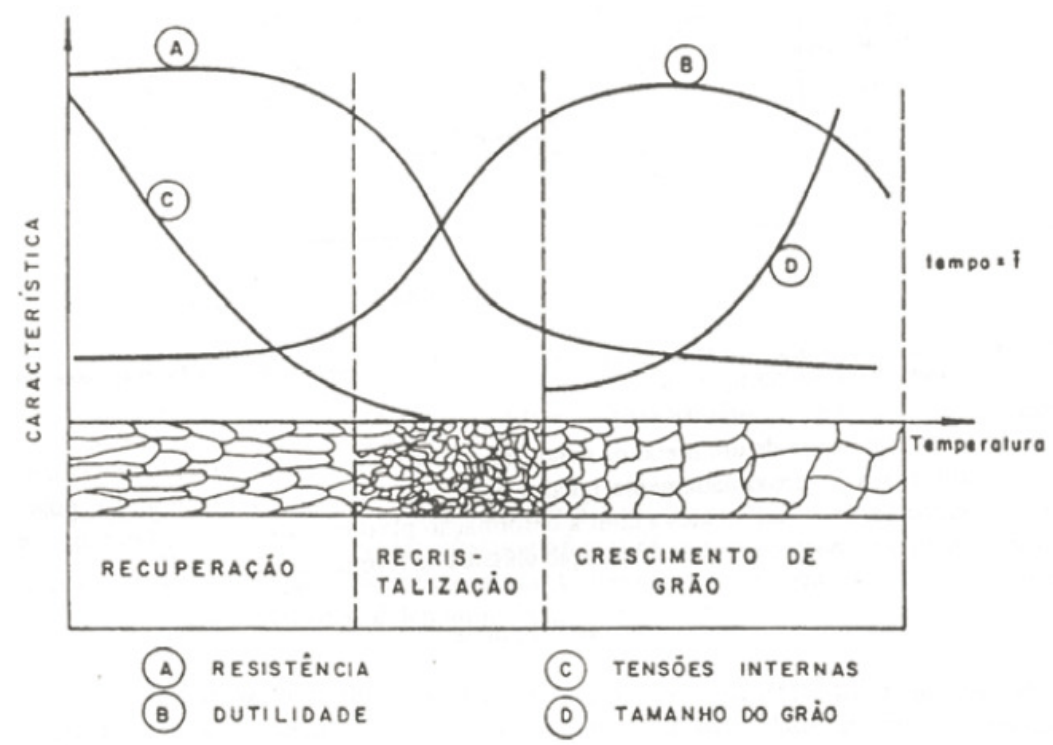

Figura 18 - Modificação da estrutura e das propriedades nas fases. [4 Modificado] 
O crescimento dos grãos segue o estágio de recristalização e ocorre com a continuidade do processo de recozimento, esse crescimento gradativo do tamanho do grão sofre interferência dos grãos circundantes e já cristalizados.

\subsection{O sistema Cu-Zr.}

A capa de eletrodo da liga $\mathrm{Cu}-\mathrm{Zr}$ é recomendada para uso em aços com revestimentos leves até média espessura e não revestidos, fabricados por conformação a frio. O cromo em eletrodos convencionais, incentiva a ligação do zinco e do cobre criando uma superfície de liga de latão que isola o eletrodo para o próximo ponto de soldagem gerando falhas. Este modelo de eletrodo é fabricado com uma liga de zircônio e cobre, isento de oxigênio.

O zircônio reduz o efeito de ligação na extremidade da capa e impede a aderência, aumentando a produtividade sem necessidades de fresagens especiais e exigências de potencias especiais para soldar materiais revestidos.

A liga cobre-zircônio possui uma boa resistência a deformação e ao desgaste devido a sua condutividade superior, que permite o uso com configurações de corrente menores e menor calor, aumentando a resistência da liga as, requer menor corrente, devido a sua maior condutividade elétrica, quando utilizado em ambos os lados da estrutura soldada, resultando em maior vida do eletrodo, soldas mais consistentes e economia de energia.

As configurações de corrente de solda podem ser reduzidas em cerca de $20 \%$ das configurações convencionais de outras ligas, sem redução na integridade da solda.

A manutenção geral das capas de eletrodo da liga cobre zircônio é muito menor do que com eletrodos convencionais, aumentando a eficiência no processo e produção. As capas não requerem aquecimento, nem tempo de condicionamento ou preparação inicial após as trocas de eletrodos.

Há uma maior expectativa de vida e economia de manutenção, menores exigências de energia e soldas com maior qualidade, o que permitem um melhor retorno sobre o investimento realizado. 
A ausência de oxigênio, permite a ligação ideal entre o cobre e o zircônio, oferecendo condutividade e maior capacidade de redução de parâmetros de corrente. A dureza em temperatura ambiente é de cerca de 65 HRB e condutividade mínima de 85\% IACS, considerado com boa resistência ao desgaste. [12]

A Figura 19 ilustra de forma detalhada a condutividade de um modelo de eletrodo de solda por resistência a ponto.

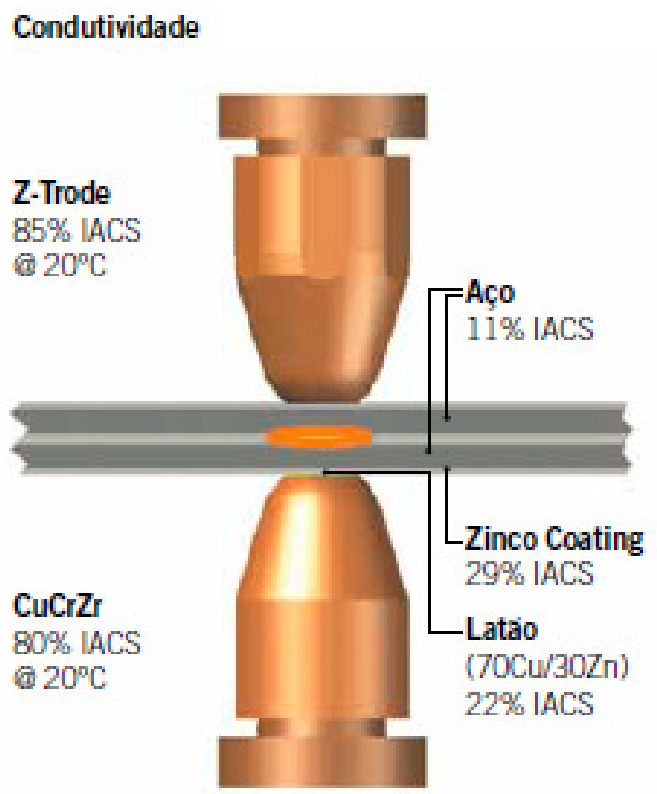

Figura 19 - Detalhamento da condutividade do Z-Trode. [12] 


\section{MATERIAIS E METODOS}

\subsection{Materiais e procedimento de soldagem}

As amostras dos eletrodos utilizados neste trabalho são do modelo MS-015, Tipo Z-Trode, classificados como Classe 1 pela RWMA, Liga Cu-Zr com 0,10\% a $0,20 \%$ de $Z r$ em sua composição química, fabricados pelo processo de estampagem a frio e endurecidos por precipitação.

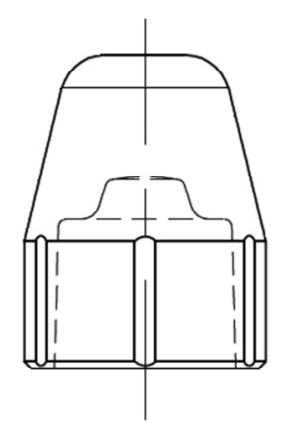

Figura 20. Ilustração esquemática do modelo de eletrodo utilizado. [Autor]

O critério de seleção das amostras levou em consideração as quantidades de eletrodos disponíveis, os intervalos entre as quantidades de pontos entre os eletrodos e a quantidades de pontos considerada relativamente alta. Entendeu-se que com essas diferenças de pontos, estaria facilitada a identificação do material, suas características e suas variações estruturais.

A opção por este modelo específico de eletrodo deu-se devido a ser o modelo de maior volume de uso na linha de montagem do veículo L200 Triton, plataforma CR47, o qual também é de grande aplicação em outros modelos de veículos fabricados na planta. Também foi considerado, que este modelo de eletrodo possui um tipo de geometria simples e com boa disponibilidade no mercado.

As chapas galvanizadas que foram soldadas pelas amostras em questão, possuem espessura média de $0,75 \mathrm{~mm}$ e são revestidas com camada de $12 \mu \mathrm{m}$ de Zn na superfície, o processo de revestimento das chapas se dá pelo processo de imersão a quente. A Figura 21 ilustra esquematicamente o lay-out com a sequência de soldagem de cada parte da carroceria, a identificação das pinças e os pontos de entrada e saída da carroceria da linha de soldagem. 


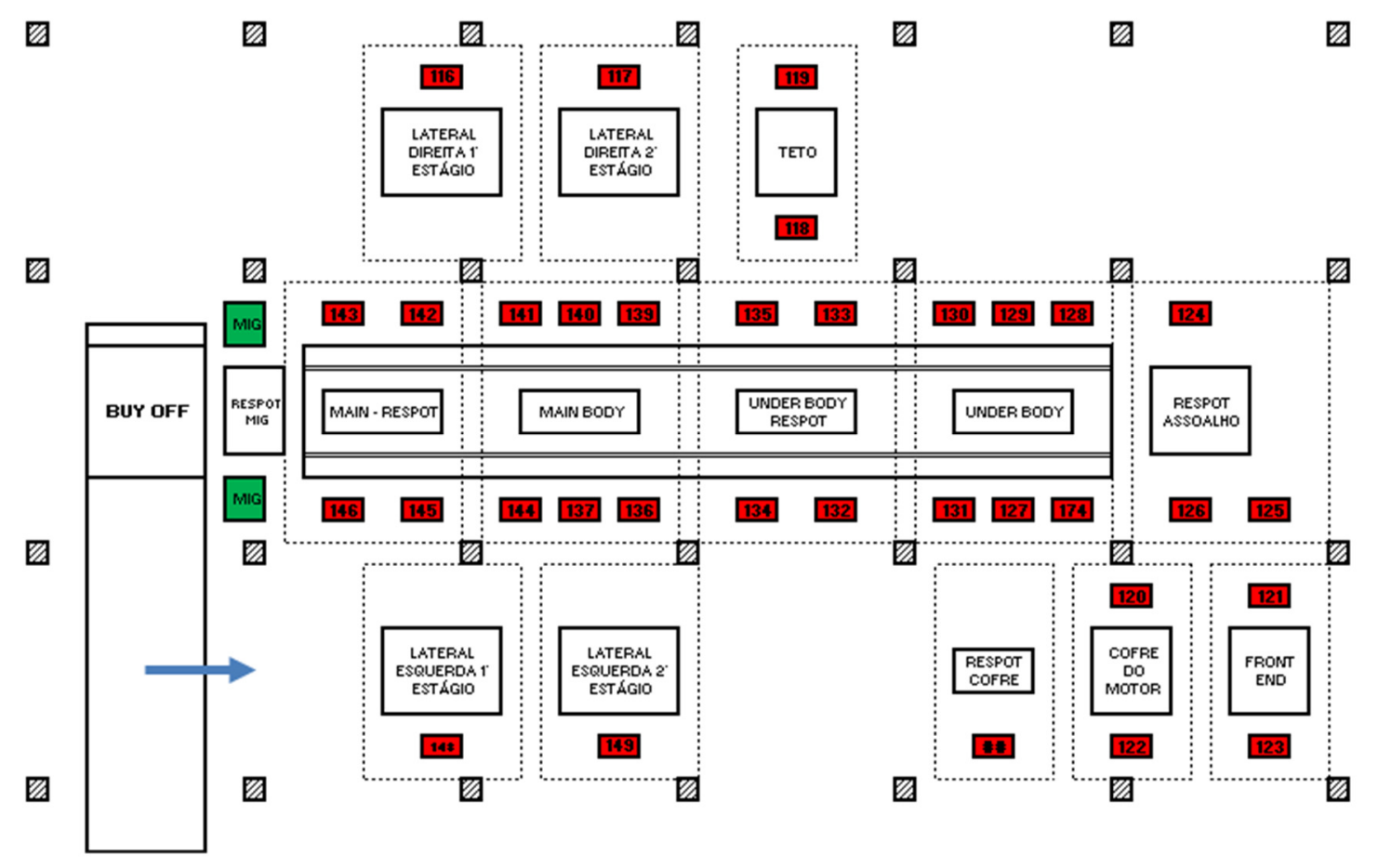

Figura 21. Ilustração esquemática da linha de soldagem da L200 Triton. [Autor]

\subsection{Parâmetros de soldagem.}

As condições de soldagem e parâmetros dos equipamentos de solda foram mantidas constantes durante a operação para todas as amostras avaliadas, essas condições de soldagem são as usualmente utilizadas na linha de montagem do modelo em condições normais de produção, essas condições correspondem a:

Pressão ou força de soldagem: 205 kgf;

Corrente de soldagem: 8 a $10 \mathrm{kA}$;

Tempo de soldagem: $450 \mathrm{~ms}$;

Velocidade de soldagem: 35 pontos por minuto;

Volume de água na refrigeração de: 8,5 I/min.

Estes parâmetros foram definidos para a soldagem dos veículos na linha de montagem do modelo Mitsubishi L200 Triton, onde o diâmetro do ponto de solda especificado, deve ser de $\varnothing 5 \mathrm{~mm}$ conforme descreve a especificação interna Mitsubishi Motors Corporation, através das normas S-X75010 e ES-X75030. 
A fresagem de cada amostra de eletrodo foi realizada em intervalos de 500 pontos de solda aproximadamente, exceto na amostra 1 que soldou 600 pontos ininterruptamente, este valor não é especificado em normas Mitsubishi e outros meios de referência, este número foi arbitrado para servir como parâmetro de controle.

A Tabela 6 mostra a sequência de identificação das amostras e o número aproximado de pontos equivalente a que cada amostra havia soldado no momento da retirada da linha de produção. O modelo de amostra número 5 representa a condição final onde os eletrodos normalmente são descartados na produção, embora possam variar o número de pontos máximos soldados por cada amostra.

Tabela 6. Identificação das amostras e o número aproximado de pontos.

\begin{tabular}{|l|c|c|c|c|c|c|}
\hline Identificação da amostra & 0 & 1 & 2 & 3 & 4 & 5 \\
\hline Número de pontos soldados & $\begin{array}{c}0 \\
\text { Como } \\
\text { concebido }\end{array}$ & 600 & 15000 & 30000 & 45000 & 60000 \\
\hline
\end{tabular}

\subsection{Caracterização das amostras.}

As amostras dos eletrodos foram preparadas usando um procedimento metalográfico padrão, na secção transversal dos eletrodos axialmente simétricos, revisão no acabamento para eliminar rebarbas e outras situações de risco, polimento automatizado utilizando lixas em sequência de grana 500,800,1200,4000, seguido de polimento intermediário com pasta de diamante de $3 \mu \mathrm{m}$ e polimento final em sílica coloidal $(0,02 \mu \mathrm{m}$ e $\mathrm{pH} 10.5)$.

Toda a área das amostras foi mapeada através de um durômetro automatizado (EMCO-TEST, modelo DuraScan 70) com carga de $3 \mathrm{~N}$ para endentações individuais. Depois disso, todas as amostras passaram por novo polimento para observação em microscópio eletrônico de varredura, (um Philips XL30, do Departamento de Engenharia Metalúrgica e de Materiais da Escola Politécnica da USP, São Paulo, Brasil e um LEO-Zeiss 1450VP, do Departamento de Engenharia de Materiais da Escola de Engenharia de Lorena, Lorena, Brasil). Em seguida, a amostra "como concebido" foi submetida ao cloreto férrico $(5 \mathrm{~g}+50 \mathrm{ml} \mathrm{Fe} 3 \mathrm{Cl} \mathrm{HCl}+100 \mathrm{ml} \mathrm{H}$ ) e observada em microscópio óptico. 


\section{RESULTADOS E DISCUSSÃO}

\subsection{Análise de dureza e micrografias ópticas}

A Figura 22 mostra os mapas de dureza das amostras de eletrodos analisadas, mapas obtidos em quadriculados com distância de $300 \mu \mathrm{m}$ entre os pontos, a amostra 0 , apresenta uma elevada dureza ao longo da área (os valores mínimos ficaram em torno de $130 \mathrm{HV}$ 3N e os maiores valores ficaram em torno de $170 \mathrm{HV} \mathrm{sN}^{\mathrm{N}}$, e foram observados na base do eletrodo e próximo a ponta do eletrodo) esse fato se deve muito provavelmente devido a região da base do eletrodo possuir um maior encruamento, pode ser atribuído ainda, ao processo de fabricação envolvido, estampagem a frio, o que induz a deformações. Após o início das operações de solda, é possível observar que a dureza diminui em toda a área do eletrodo, alcançando valores de dureza muito baixos, cerca de $75 \mathrm{HV}_{3 \mathrm{~N}}$, localizado próximo a ponta do eletrodo, portanto uma queda significativa de dureza se comparada a amostra 0 .

Esta região do eletrodo, está sujeita a maiores tensões e temperaturas durante o processo de formação do ponto. As variações estatísticas existentes entre as amostras devem ser observadas, porém de maneira geral, há uma tendência de amolecimento progressivo do interior da peça. Além disso, é importante observar que, como o número de pontos soldados cresce, o eletrodo é progressivamente consumido seja por desgaste ou por dressagem, portanto, a baixa dureza da ponta do eletrodo se move em direção a base do eletrodo com o prosseguimento das operações.

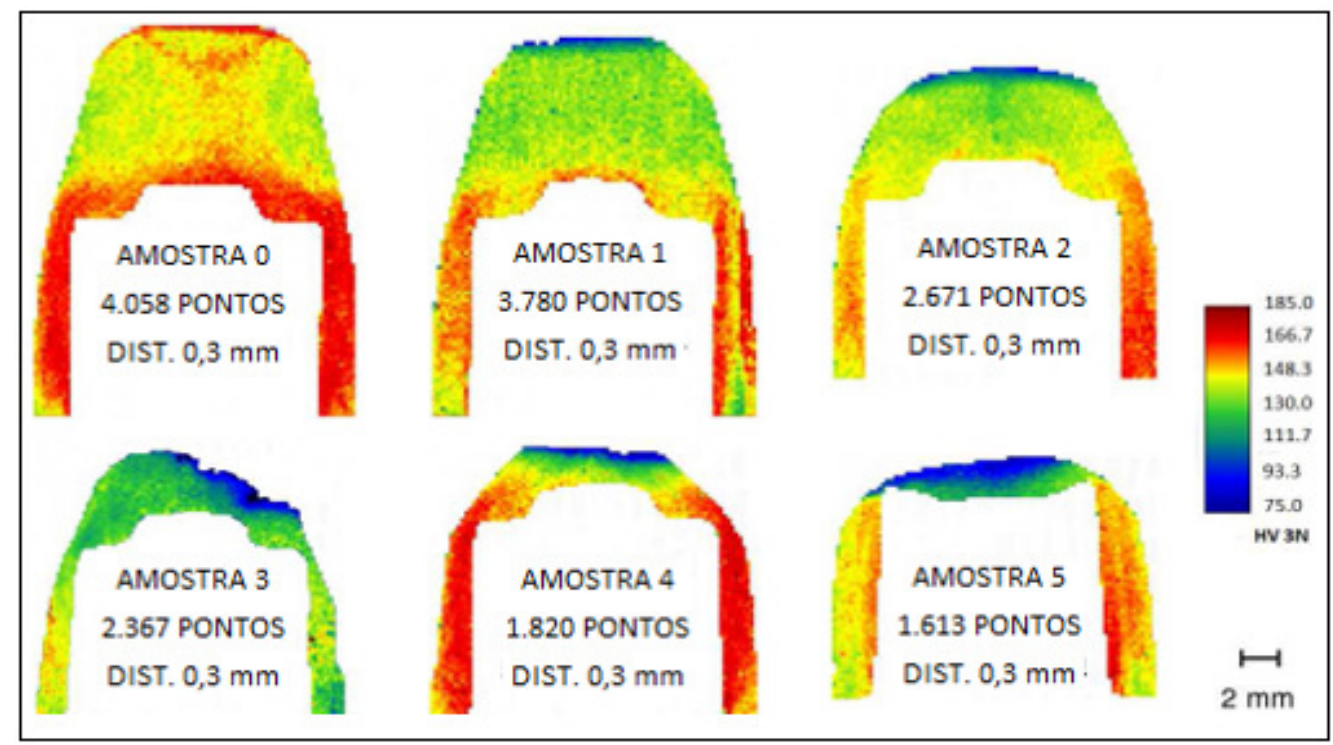

Figura 22. Mapas de dureza das amostras de eletrodos $\left(\mathrm{HV}_{3 \mathrm{~N}}\right)$. 
A Figura 23 (a) mostra a microestrutura perto da ponta da amostra "como concebido" onde é possível observar grãos alongados (característica micro estrutural de um cobre trabalhado a frio) que repentinamente mudam de direção próximo a ponta do eletrodo. Este trabalho a frio "adicional" é provavelmente vinculado a dureza excedente observada no mapa de dureza (amostra 0). A região de transição é mostrada em detalhe na Figura 23 (b). A imagem obtida no modo eletrônico retroespalhado, mostra que a estrutura deformada na região próxima a ponta do eletrodo é consideravelmente mais fina, quando comparada com o núcleo da amostra, o que corrobora com o encruamento adicional. A imagem também detalha a morfologia de precipitados ricos em Zircônio (precipitados brilhantes, aproximadamente $16 \% \mathrm{Zr}$, de acordo com a análise EDS).

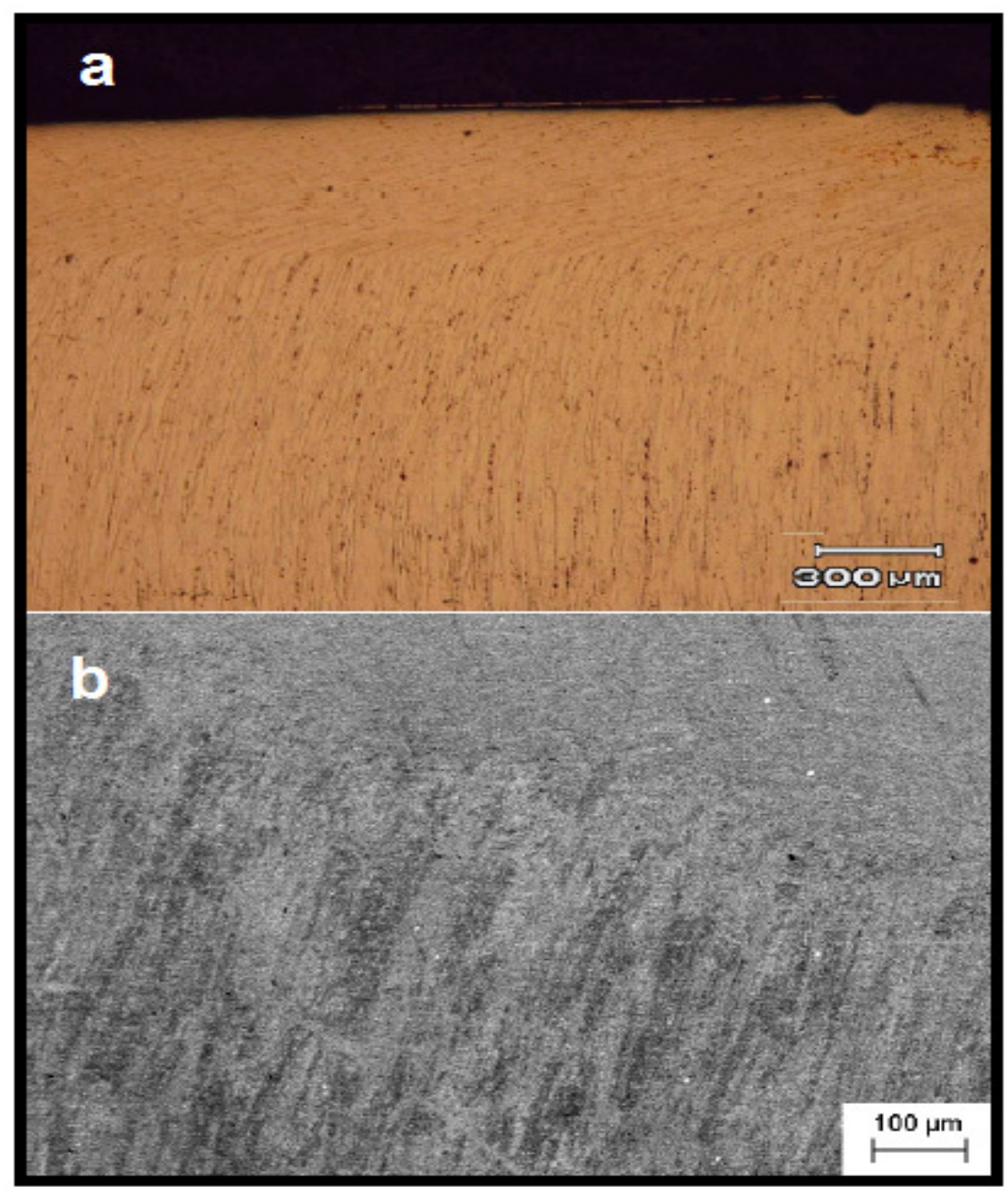

Figura 23. Micrografia óptica da amostra "como concebido" (a) perto da ponta do eletrodo (borda superior na imagem), submetido a cloreto férrico e (b) detalhe da região de transição entre as regiões axialmente alinhadas e não alinhadas axialmente da amostra. Imagem eletrônica retro espalhada. 
A Figura 24 mostra a microestrutura perto da ponta do eletrodo para a amostra 1 (600 pontos soldados), mostrando que, inicialmente, nenhuma alteração na microestrutura pode ser identificada. A ausência de alteração pode ser atribuída a uma consequência da primeira operação de dressagem aplicada na amostra antes de ser coletada.

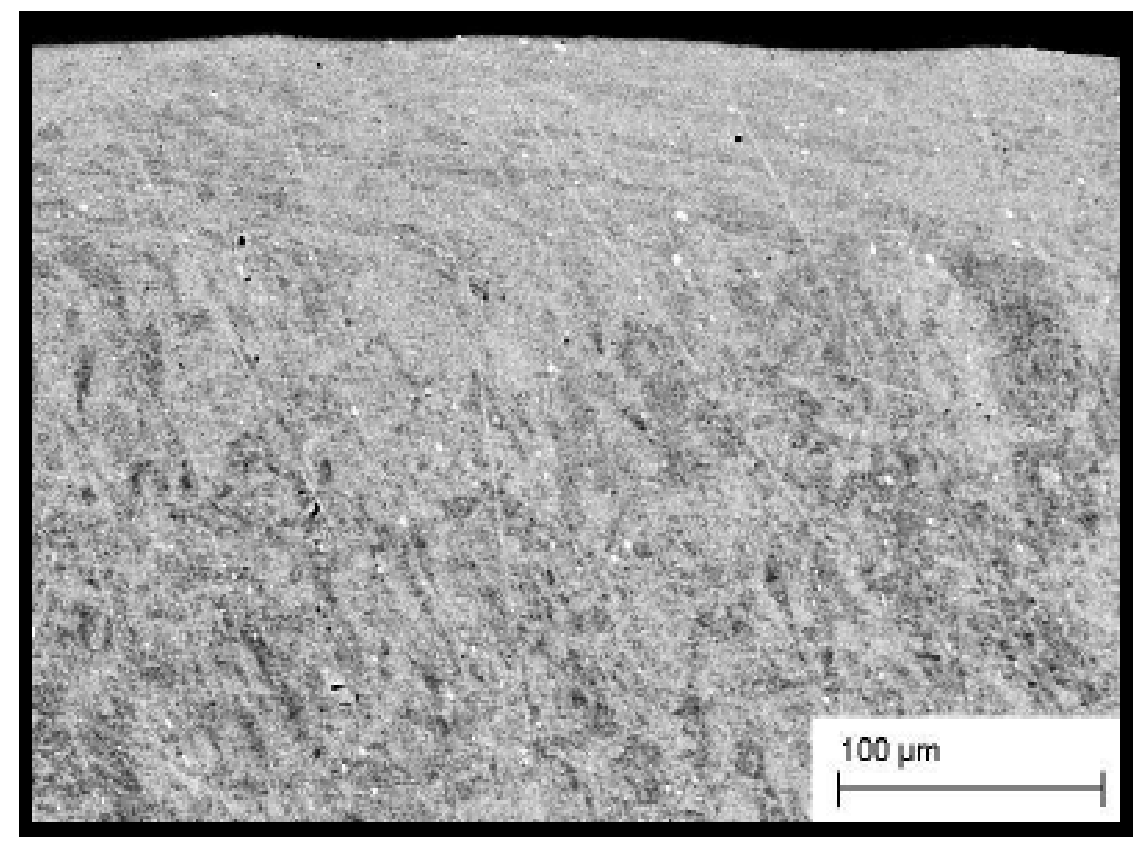

Figura 24. Danos perto da ponta do eletrodo amostra 1. Imagem obtida no modo eletrônico retro espalhado.

A Figura 25 mostra o dano próximo a ponta do eletrodo para a amostra 2 (15000 pontos de solda). Uma camada distinta é agora observada na superfície.

Esta camada é chamada de "latão" conforme relatado na literatura. No interior da amostra (substrato da camada de "latão") características diferentes são observadas, estas características são típicas de uma matriz trabalhada a frio.

Considerando que a região amolecida nesta amostra é de $3 \mathrm{~mm}$ de profundidade, é possível concluir que o mecanismo de recuperação ou, talvez a variação de dureza está ocorrendo, mesmo sem mudanças aparentes na estrutura de deformação. O entendimento do fenômeno ocorrido nesta região da amostra 2, pode ser melhor caracterizado através da análise da Figura 22. 


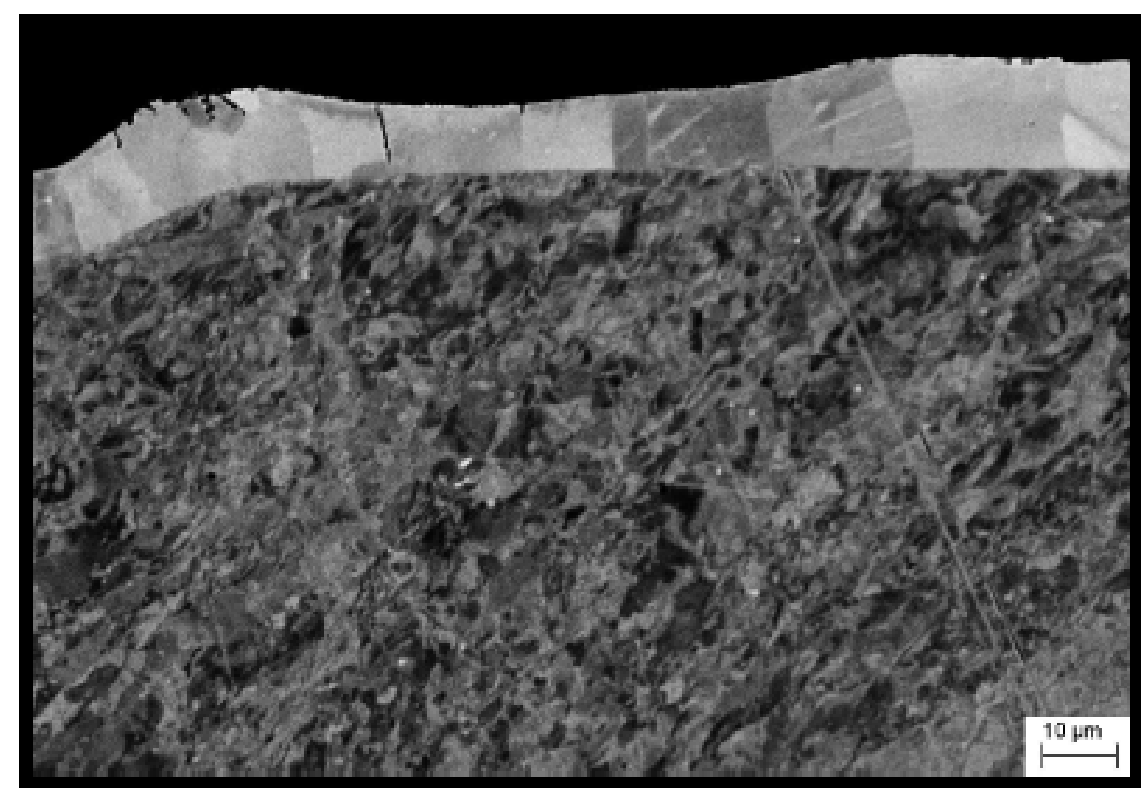

Figura 25. Danos perto da ponta do eletrodo amostra 2.

Imagem obtida no modo eletrônico retro espalhado

A Figura 26 mostra a microestrutura perto da ponta do eletrodo na amostra 3 (30000 pontos soldados). Nenhuma camada de "latão" foi observada em toda a amostra. A ausência da camada de "latão" na amostra 3 pode ser caracterizada por consequência da retirada da amostra logo após ser aplicada a operação de dressagem na amostra. Como no caso da amostra 2, onde nenhuma alteração pode ser observada na estrutura de deformação do substrato.

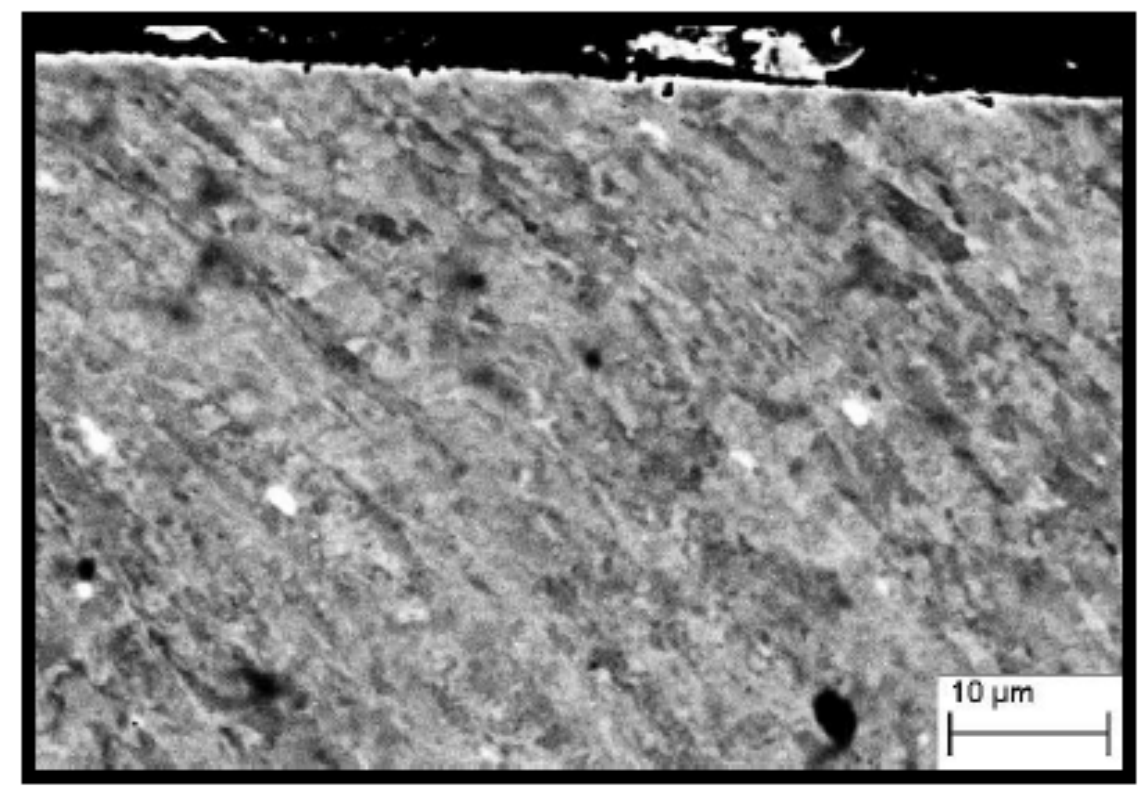

Figura 26: Danos perto da ponta do eletrodo amostra 3. Imagem obtida no modo eletrônico retro espalhado 
Esta situação muda para a amostra 4 (45000 pontos de solda). A Figura 27 mostra mais uma vez a presença de "latão" mas agora a matriz apresenta regiões equiaxiais, as quais estavam ausentes nas amostras anteriores. Esta microestrutura pode ser interpretada como o resultado da recristalização incompleta, levando a um refino de grão (as regiões equiaxiais possuem cerca de $5 \mu \mathrm{m}$ de diâmetro). A ausência de um forte contraste entre algumas características individuais, a ausência de um ponto descontinuo de dureza no mapa de dureza (Figura 22) e da evidente falta de crescimento dos grãos em algumas áreas (Figura 27) sugerem que a desorientação entre estas regiões não deve ser grande e os contornos observados podem ser, portanto os contornos dos grãos.

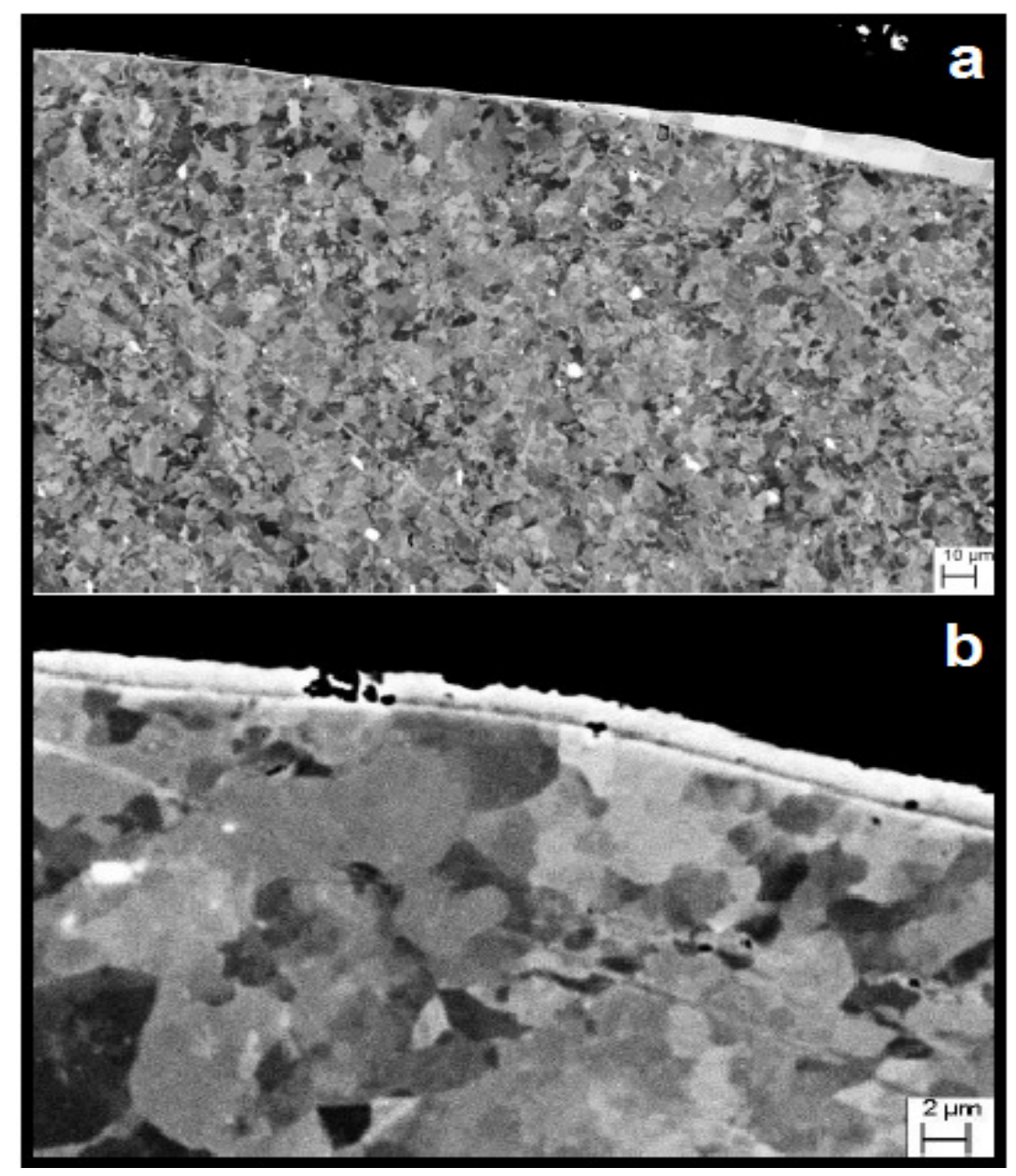

Figura 27. Danos perto da ponta do eletrodo na amostra 4: (a) vista geral da camada de "latão" e (b) detalhe da estrutura de deformação perto da ponta do eletrodo. Imagem eletrônica retro espalhada.

Analise EDS da camada de "latão" e da matriz adjacente de Zn levam ao conteúdo de 32 a $33 \%$ em peso da matriz e em 46,5 a $47 \%$ em peso na camada. Estes 
valores são consideravelmente próximos do equilíbrio da composição da fase $\alpha$ e fase $\beta$ abaixo da reação peritética em Cu-Zn no diagrama de fazes. (Figura 28)

A Figura 28 poderia ser utilizada para explicar a formação da camada de "latão". A medida em que a corrente é acionada, o zinco derrete, dissolvendo parte do cobre do eletrodo e formando um liquido rico em zinco, a composição segue a linha líquidus até que a temperatura de processamento é atingida. $A$ fase $\beta$ é cubica de corpo centrado e apresenta maior difusividade em comparação com matriz cubica de face centrada. Kuper et. al [23] no relatório de difusividade de cobre e zinco na fase $\beta$, obteve valores para o intervalo de temperatura entre 1023 e $1123 \mathrm{~K}$ cerca de $2,1 \times 10^{-}$ ${ }^{7}$ e $5,5 \times 10^{-7} \mathrm{~cm}^{2} \mathrm{~s}^{-1}$ para o cobre e $3,2 \times 10^{-7}$ a $7,4 \times 10^{-7} \mathrm{~cm}^{2} \mathrm{~s}^{-1}$ para o zinco. Utilizando o menor destes valores, o tempo necessário para formar uma camada de $10 \mu \mathrm{m}$ de fase $\beta$ por difusão direta seria $4,8 \mathrm{~s}$. A soldagem por resistência elétrica é um processo rápido, porém, mesmo assim a corrente elétrica permanece ativada por cerca de 150 ms a cada ponto, portanto, o equilíbrio completo para a difusividade poderia ser alcançado após alguns pontos serem soldados.

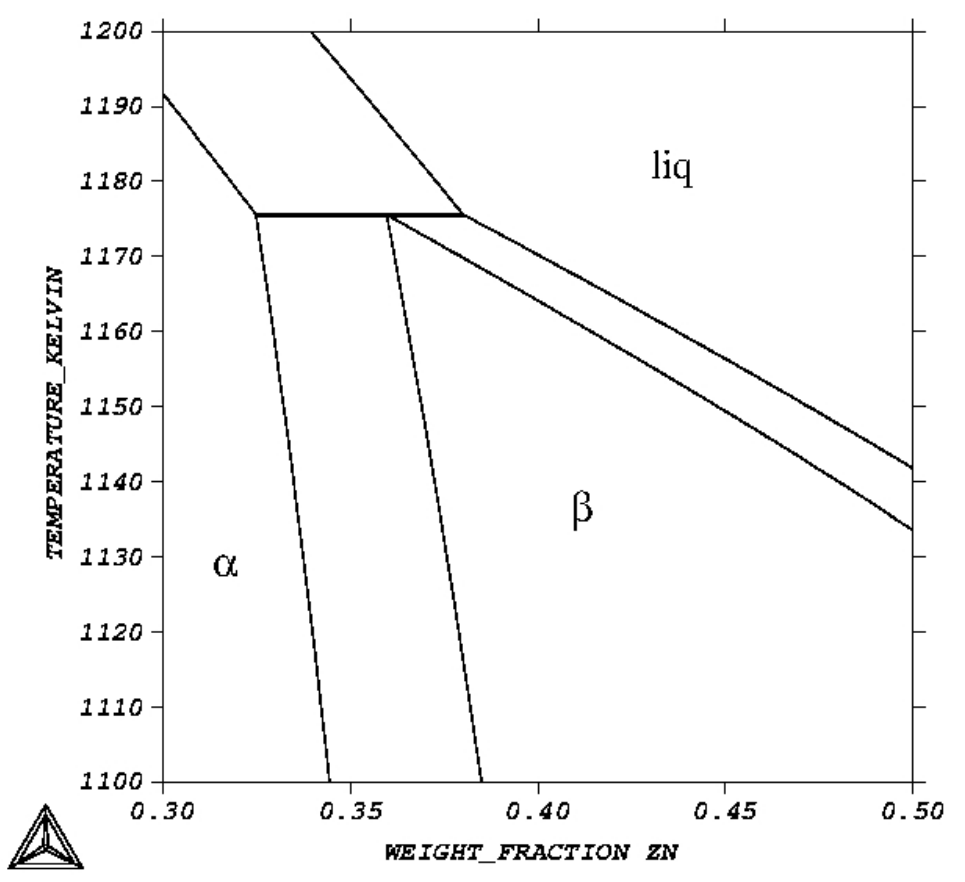

Figura 28: Detalhe do diagrama de fase $\mathrm{Cu}$ - Zn na região de estabilidade da fase.

Os danos na matriz, no entanto, não estão limitados a formação da camada de "latão". A medida que o eletrodo se aproxima do fim da vida, (Figura 29 a) precipitados 
adicionais são vistos na matriz. A Figura 29 b mostra um exemplo. Ela mostra uma partícula branca associada com uma outra mais escura. Apesar da profunda tonalidade escura na imagem eletrônica retro espalhada, esta não é uma cavidade, como se pode provar, observando a mesma área no modo de elétrons secundários. A análise EDS não é determinante, mas a partícula branca parece ser o mesmo precipitado observado nas imagens anteriores (provavelmente $\mathrm{Cu}_{9} \mathrm{Zr}_{2}$ ) a partícula escura é mais rica em zircônio e em oxigênio, mas a composição exata da mesma não pode ser determinada. A camada de "latão" nesta amostra também foi observada e percebe-se também a presença de oxigênio.

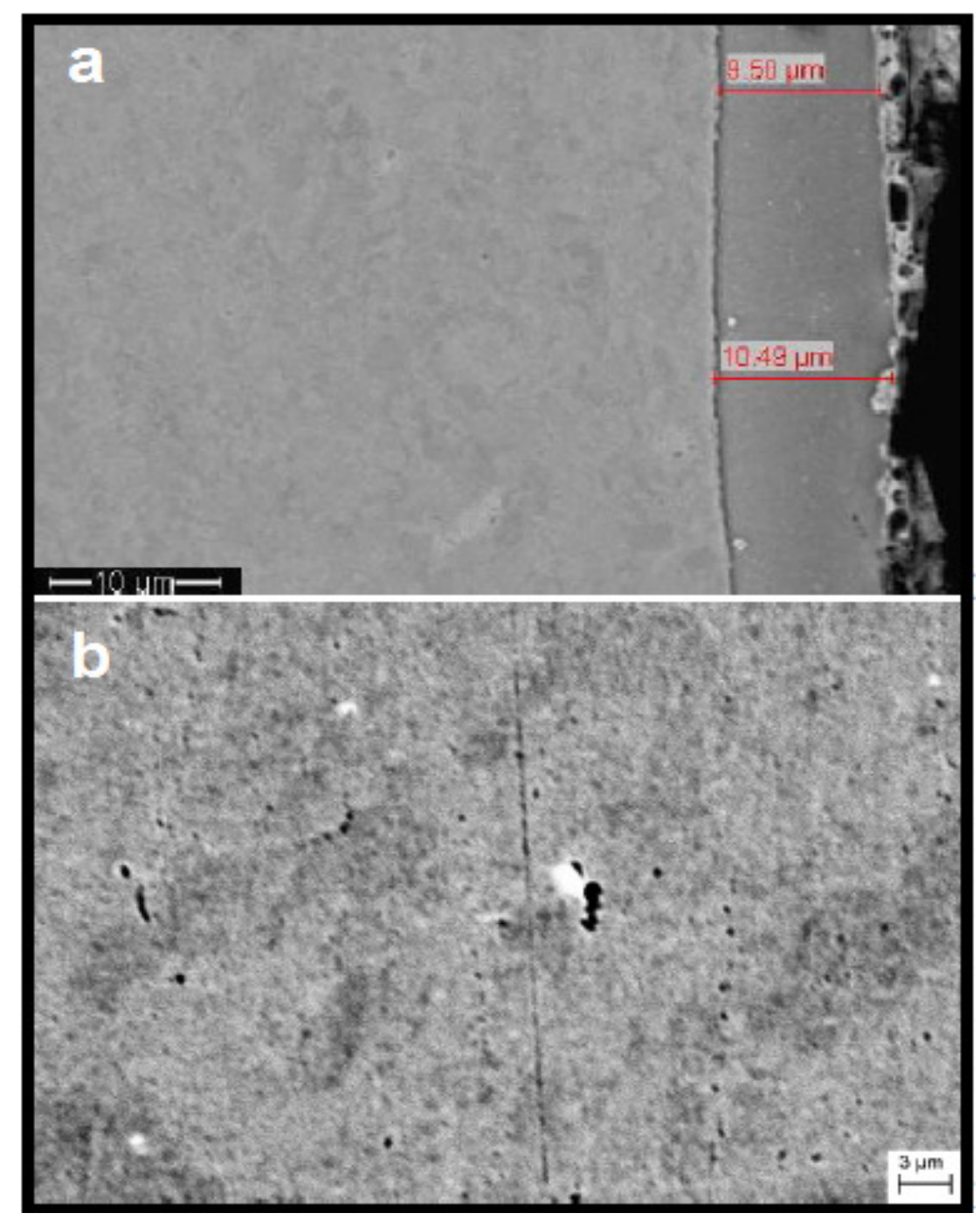

Figura 29: Detalhes da Amostra 5 (60000 pontos): (a) aspecto geral da camada de "latão" e (b) exemplo de interação entre precipitados de zircônio e precipitados ricos em oxigênio (partículas escuras). 


\subsection{Análise da correlação entre área do eletrodo versus número de pontos}

A análise comparativa entre a área da seção transversal do eletrodo pelo total de pontos soldados de cada amostra foi realizada com auxílio da Lupa Estereoscópica Zeiss, Axio Stemi $2000 \mathrm{C}$, lente de 0,3 e aumento de 1,6, utilizando-se o programa Vision SE64, com escala de $5 \mathrm{~mm}$. Os dados foram registrados na Tabela 7 de forma simples para comparação dos dados.

Tabela 7. Área da seção transversal de acordo com o número de pontos soldados

\begin{tabular}{|c|c|c|}
\hline AMOSTRA & NUMERO DE PONTOS & ÁREA mm2 \\
\hline 0 & Como concebido & 164,17 \\
\hline 1 & 500 & 163,19 \\
\hline 2 & 15000 & 126,43 \\
\hline 3 & 30000 & 105,22 \\
\hline 4 & 45000 & 84,8 \\
\hline 5 & 60000 & 73,4 \\
\hline
\end{tabular}

O gráfico mostra a relação da área da seção transversal do eletrodo pelo número de pontos soldados.

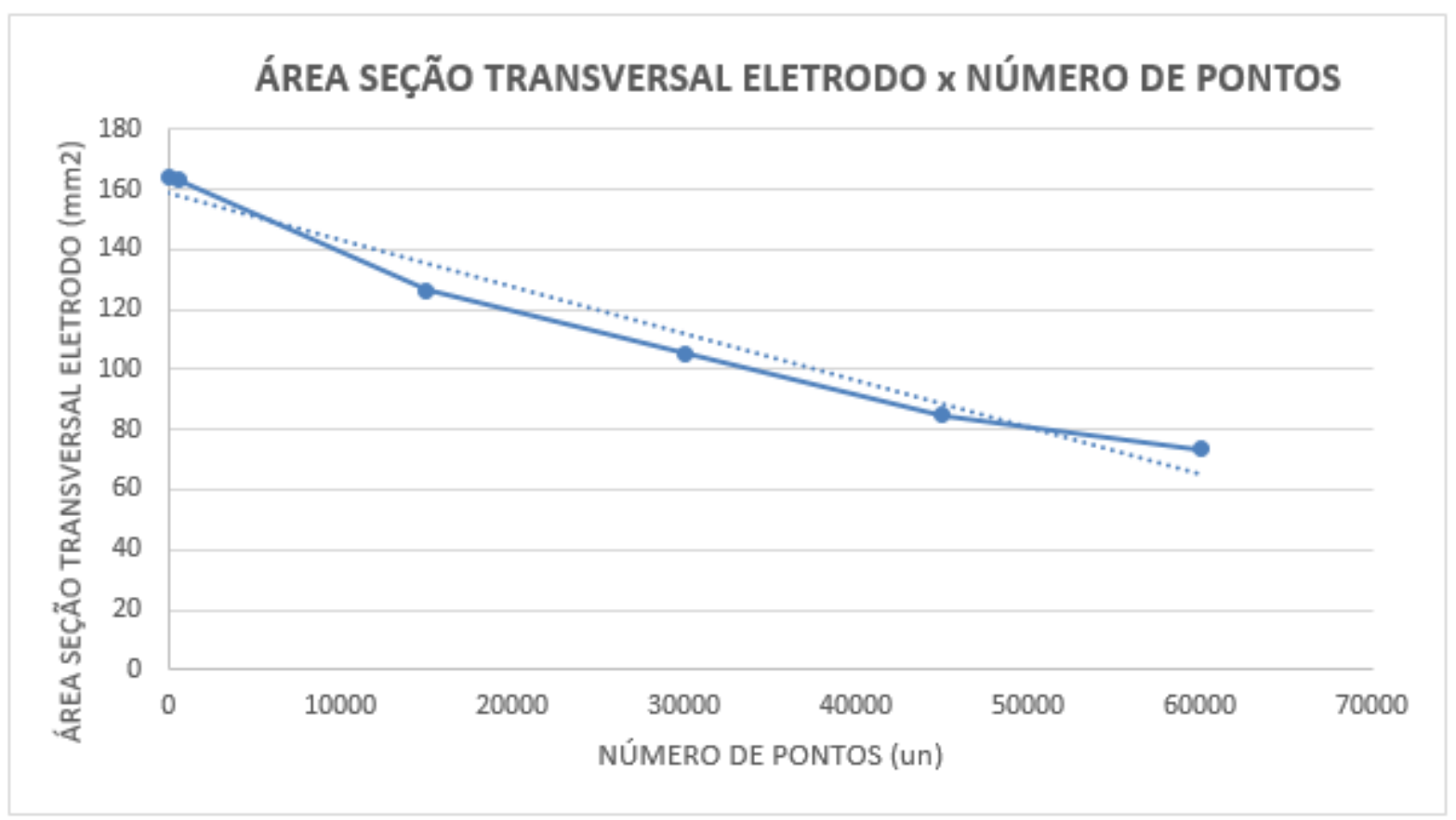

Figura 30. Gráfico da área da seção transversal do eletrodo x Número de pontos soldados. 


\subsection{Estudo comparativo dos processos de fresagem}

O processo de dressagem manual feito através de lima foi subsituido internamente pelo processo mecanizado através de dressadoras, o estudo comparativo mostra os resultados encontrados.

O estudo teve por finalidade avaliar os ganhos em produtividade e financeiro envolvido no processo interno de dressagem, além de considerar um relativo ganho em qualidade no ponto de solda.

O estudo inicial foi realizado em apenas uma linha de soldagem, após a comprovação dos resultados, o processo foi estendido a todas as linhas de montagem de veículos da fábrica. A Tabela 8 mostra o detalhamento do estudo comparativo.

Tabela 8. Estudo comparativo. Dressagem com lima x Dressagem mecanizada

\begin{tabular}{|c|c|c|c|}
\hline Dressagem com a lima & & Dressagem com a máquina & \\
\hline Dias trabalhados (mês) & 20 & Dias trabalhados (mês) & 20 \\
\hline Qdade de Pinça & 24 & Qdade de Pinça & 24 \\
\hline Tempo de Dressagem (min.) & 0,40 & Tempo de Dressagem (min.) & 0,37 \\
\hline Dressar a cada 4 veículos & 4 & Dressar a cada 4 veículos & 112 \\
\hline Veículos por dia & 18,67 & Veículos por dia & 18,67 \\
\hline Qdade de Dressagem por pinça dia & 4,67 & Qdade de Dressagem por pinça dia & 0,17 \\
\hline Qdade de Dressagem por Pinça mês & 93,35 & Qdade de Dressagem por Pinça mês & 3,33 \\
\hline Qdade de Dressagem para 24 (Pinças) mês & 2240,4 & Qdade de Dressagem para 24 (Pinças) mês & 80,01 \\
\hline Tempo de Dressagem das 24 pinças/mês (min.) & 896,16 & Tempo de Dressagem das 24 pinças/mês (min.) & 29,61 \\
\hline Tempo de Dressagem das 24 pinças/mês (hrs.) & 14,936 & Tempo de Dressagem das 24 pinças/mês (hrs.) & 0,49 \\
\hline Custo M.O.D. (R\$/hora) & $\mathrm{R} \$ 12,84$ & Custo M.O.D. (R\$/hora) & $\mathrm{R} \$ 12,84$ \\
\hline Custo de Dressagem das 24 pinças/Dia & $\mathrm{R} \$ 9,59$ & Custo de Dressagem das 24 pinças/Dia & $\mathrm{R} \$ 0,32$ \\
\hline Custo de Dressagem das 24 pinças/Mês & $\mathrm{R} \$ 191,79$ & Custo de Dressagem das 24 pinças/Mês & $\mathrm{R} \$ 6,34$ \\
\hline Custo de Dressagem das 24 pinças/Ano & $\mathrm{R} \$ 2.301,44$ & Custo de Dressagem das 24 pinças/Ano & $\mathrm{R} \$ 76,03$ \\
\hline Custo de cada Dressagem $\mathrm{R} \$$ & $\mathrm{R} \$ 0,09$ & Custo de cada Dressagem R\$ & $\mathrm{R} \$ 0,08$ \\
\hline Custo de cada Dressagem por pinça dia (R\$̦) & $\mathrm{R} \$ 0,40$ & Custo de cada Dressagem por pinça dia (R\$̦) & $\mathrm{R} \$ 0,01$ \\
\hline
\end{tabular}

Após a análise detalhada do estudo comparativo entre os tipos de dressagem, foi possível verificar os ganhos gerais que a dressagem pneumática apresenta em comparação com a dressagem manual, sendo preferível o uso do sistema de dressagem pneumática, ou seja, com o uso de máquina. 


\section{CONCLUSÕES}

- A variação de dureza do eletrodo está ligada diretamente ao aumento da temperatura e ao desgaste. Quanto maior a dureza, menor o desgaste, e quanto menor a dureza, maior o desgaste, desta forma, a durabilidade e a produtividade dos eletrodos passam pela capacidade de cada liga de suportar e manter a dureza em determinadas temperaturas.

- Verificou-se uma redução na dureza do eletrodo, primeiramente na ponta do eletrodo, região que está sujeita a altas temperaturas e altas pressões, porém verificou-se que no final todas as partes perdem dureza.

- A interação do zinco em contato com o eletrodo e a chapa de aço conduz a formação de uma camada rica em zinco cuja composição é consistente com o intermetálico Cu$\mathrm{Zn}$.

- Esse enriquecimento em zinco mostra que a dressagem controlada é parte fundamental do processo de soldagem podendo representar uma melhora na qualidade do ponto de solda.

- No fim da vida útil das peças, a interação com o oxigênio é observada sob forma de precipitados ricos em oxigênio associados com as partículas ricas em $\mathrm{Zr}$ que fazem parte da liga. Isto sugere que a função do zircônio presente na liga não é só para reforçar a liga, uma vez que é geralmente assumido, mas também para ligar oxigênio dissolvido, o que poderia de outra forma, formar regiões de baixa fusão eutética, aumentando e muito o desgaste do eletrodo.

- O estudo comparativo entre os processos de dressagem manual e com o uso de máquina, mostra que o processo de dressagem através de máquina pneumática, apresenta maior eficiência e significativa redução de custos ao longo do uso 


\section{REFERÊNCIAS BIBLIOGRÁFICAS}

1 BRANDI, S.D. Soldagem por resistência. In: WAINER, E. et al. Soldagem: Processos e Metalurgia. São Paulo: Edgard Blücher Ltda, 1992.

2 FUKUMOTO, S. et al. Effects of Electrode Degradation on Electrode Life in Resistance Spot Welding of Aluminum Alloy 5182. Welding Journal, November 2003.

3 MARQUES, P.V.; MODENESI, J.Q.; BRACARENSE, A.Q. Soldagem:Fundamentos e Tecnologia. Belo Horizonte: UFMG, 2005.

4 BRANCO, Hideraldo Luiz Osório. Avaliação de capas de eletrodos utilizadas na soldagem por resistência de chapas galvanizadas automotivas. Dissertação de Mestrado. UFPR. 2004

5 BLAKELEY, P. Resistance Spot Welding - at Maximum Speed. Welding \& Metal Fabrication, Sep. 2000.

6 ZIEDAS, S; TATINI, I. Coleção Tecnologia SENAI: Soldagem. São Paulo: SENAI, 1957.

7 MACHADO, Ivan Guerra. Soldagem \& Técnicas Conexas: Processos. Porto Alegre: Editado pelo Autor, 1996.

8 GUEDES, J.B.P., GONÇALVES, R.A. \& SCOTTI. A., Avaliação de Desgaste de Eletrodos em Solda a Ponto por Resistência de Chapas Galvanizadas, XXX Consolda - Congresso Nacional de Soldagem, ABS, 13 a 15 de Setembro de 2004, Rio de Janeiro, RJ.

9 Intermachinery Comércio Ltda. Manual de Treinamento do Z-Trode e Nitrode. 2002. 
10 BAM SOLDAS. Apostila de Solda Bam. Tecnologia em Solda por Resistência. Disponível em http://www.bamsoldas.com.br/informativos/cursodesolda.pdf. Acessada em 25 de janeiro de 2015.

11 FURLANETTO, V. Proposta e validação experimental de um modelo para máquina de solda a ponto CA. USP, 2005. 88 p. Dissertação de Mestrado. Escola Politécnica, Universidade de São Paulo, São Paulo, 2005.

12 KUPER, A.B., et al. Diffusion in ordered and disordered Copper - Zinc. Phys Rev 1956;104:1536- 1541 .

13 BATISTA, M. Estudo comparativo da soldabilidade de chapas para indústria automotiva utilizando dois equipamentos de soldagem a ponto por resistência. Dissertação de Mestrado; Escola Politécnica da Universidade de São Paulo; São Paulo; 2011.

14 NASCIMENTO, Vinicius Castanheira do,. Seleção de parametros de soldagem a ponto por resistencia, baseado na medição da resistencia eletrica entre chapas. Dissertação de Mestrado. UFU-MG. 2008.

15 TECNOWELDING Comércio Ltda. Apostila. Fundamentos do Processo de Soldagem a Resistência. 2004.

16 DICKINSON, D.W.; FRANKLIN. J.E.; STANYA, A. Characterization of Spot Welding Behavior by Dinamic Elctrical Parameter Monitoring Welding Research Council, New York, June 1980.

17 AWS - American Welding Society, Jefferson`s Welding Enciclopedia. $18^{\text {th }}$ Edition. Miami: 1997.

18 STOCCO, Danilo. Caracterização de solda por resistência a ponto através de avaliações não destrutivas. Dissertação de Mestrado. Escola Politécnica da Universidade de São Paulo; São Paulo, 2010. 
19 AMOUYAL. Y. et al. Short-circuit diffusion in an ultrafine-grained copper-zirconium alloy produced by equal channel angular pressing. Elsevier. ScienceDirect. Acta Materialia. 55. 2007. 5968-5979.

20 TSCHIPTCHIN, A.P. et al. Textura e relações de orientação. Deformação plástica, recristalização, crescimento de grão. São Paulo: EPUSP. 2ª Ed. 2003.

21 RWMA - Resistance Welder Manufacturers Association. Eletrodos e Ferramentas Utilizadas no Processo de Soldagem por Resistência Elétrica. 2002.

22 INFOMET. Site informativo. Disponível em: www.infomet.com.br Acessado em 08 de outubro de 2014.

23 ETS - Especificação Técnica de Soldagem. Apostila. Manual de Dressagem. ETS. 2000.

24 CALLISTER, W. D. JR. Ciência e Engenharia de Materiais: Uma introdução. LTC. 7를. Ed. Rio de Janeiro. 2008.

25 DOBATKIN, S.V. et al. Effects of deformation schedules and initial states on structure and properties of $\mathrm{Cu}-0,18 \% \mathrm{Zr}$ alloy after high-pressure torsion and heating. Elsevier. Materials Science \& Engineering. A 598. 2014. 288-292.

26 EDALATI. K., HORITA. Z., High-pressure torsion of pure metals: Influence of atomic bond parameters and stacking fault energy on grain size and correlation with hardness. Elsevier. ScienceDirect. Acta Materialia. 59. 2011. 6831-6836.

27 LUVATA. Disponível em: www.luvata.com Catalogo Z-TRODE 2013. Acessado em 11 de outubro de 2014.

28 WELDING SCIENCE. Manual de treinamento de soldagem por resistência. São Paulo, 2009. 
29 ZHANG, H; SENKARA, J. Resistance Welding: Fundamentals and Applications.

1. Ed. London: Taylor \& Francis, 2006.

30 MINERAÇÃO E METALURGIA. Agregando Qualidade: Aços Galvanizados.

Setembro, $N^{\circ}$ 38, Área de Operações Industriais 2, Gerência Setorial 3, Editoração: GESIS/AO2, 2000.

31 NIPPERT. A comparison of the Resistance Spot Weldability of Bare, Hot-Dipped, Galvannealed, and Electrogalvanized DQSK, Sheels, SAE N ${ }^{\circ} 80280$, Feb. 1988. 